\title{
Lower Columbia River and Estuary Habitat Monitoring Study, 2011
}

\section{FINAL REPORT}

Amy B. Borde

Ronald M. Kaufmann

Valerie I. Cullinan

Shon A. Zimmerman

Ronald M. Thom

Cynthia L. Wright

March 2012

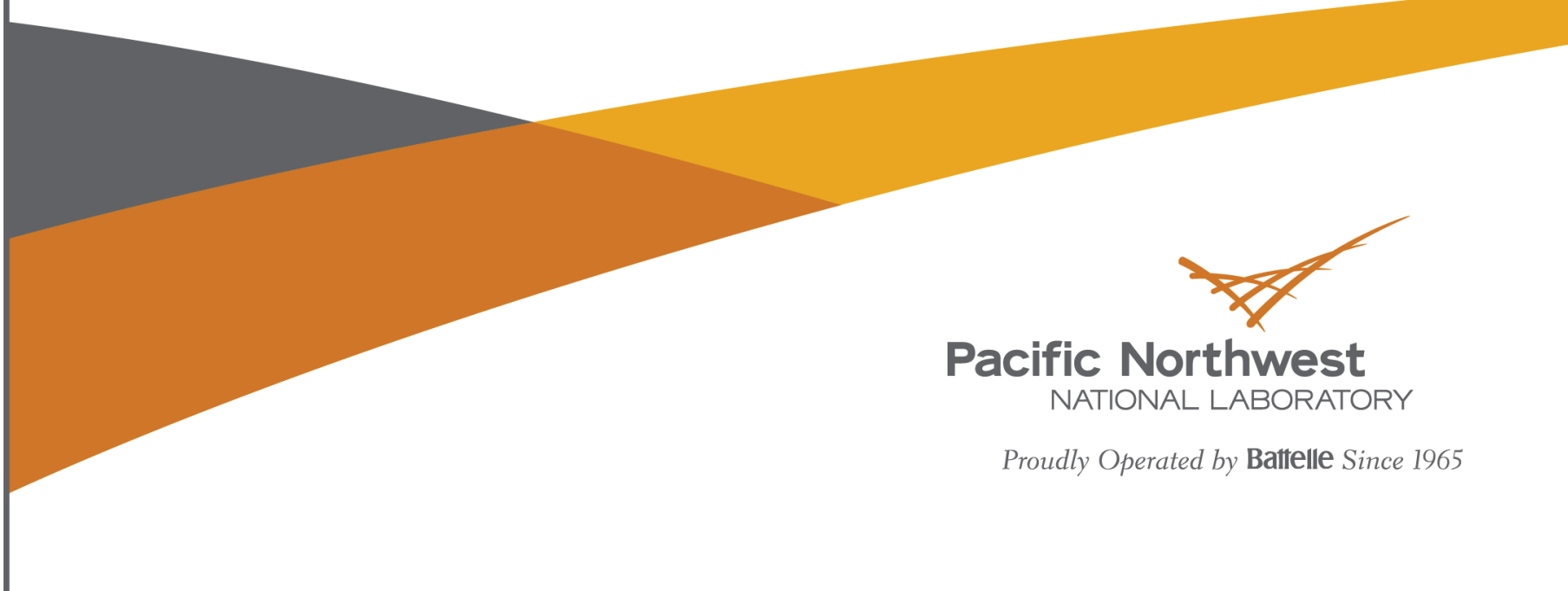




\title{
Lower Columbia River and Estuary Habitat Monitoring Study, 2011
}

\author{
Amy B. Borde \\ Ronald M. Kaufmann \\ Valerie I. Cullinan \\ Shon A. Zimmerman \\ Ronald M. Thom \\ Cynthia L. Wright
}

March 2012

Prepared for

The Lower Columbia River Estuary Partnership

under U.S. Department of Energy Contract DE-AC05-76RL01830

Pacific Northwest National Laboratory

Richland, Washington 99352 


\title{
DISCLAIMER
}

This report was prepared as an account of work sponsored by an agency of the United States Government. Neither the United States Government nor any agency thereof, nor Battelle Memorial Institute, nor any of their employees, makes any warranty, express or implied, or assumes any legal liability or responsibility for the accuracy, completeness, or usefulness of any information, apparatus, product, or process disclosed, or represents that its use would not infringe privately owned rights. Reference herein to any specific commercial product, process, or service by trade name, trademark, manufacturer, or otherwise does not necessarily constitute or imply its endorsement, recommendation, or favoring by the United States Government or any agency thereof, or Battelle Memorial Institute. The views and opinions of authors expressed herein do not necessarily state or reflect those of the United States Government or any agency thereof.

\author{
PACIFIC NORTHWEST NATIONAL LABORATORY \\ operated by \\ BATTELLE \\ for the \\ UNITED STATES DEPARTMENT OF ENERGY \\ under Contract DE-AC05-76RL01830
}

Printed in the United States of America
Available to DOE and DOE contractors from the Office of Scientific and Technical Information,
P.O. Box 62, Oak Ridge, TN 37831-0062;
ph: (865) 576-8401
fax: $(865)$ 576-5728
email: reports@adonis.osti.gov

\begin{abstract}
Available to the public from the National Technical Information Service, U.S. Department of Commerce, 5285 Port Royal Rd., Springfield, VA 22161 ph: (800) 553-6847 fax: $(703) 605-6900$ email: orders@ntis.fedworld.gov online ordering: http://www.ntis.gov/ordering.htm
\end{abstract}

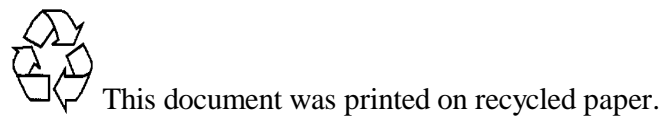





\section{Acronyms and Abbreviations}

$\begin{array}{ll}\text { BPA } & \text { Bonneville Power Administration } \\ \text { CRD } & \text { Columbia River Datum } \\ \text { GIS } & \text { Geographic Information System } \\ \text { GPS } & \text { Global Positioning System } \\ \text { LCRE } & \text { Lower Columbia River and Estuary } \\ \text { LCREP } & \text { Lower Columbia River Estuary Partnership } \\ \text { MLLW } & \text { Mean Lower Low Water } \\ \text { NAVD88 } & \text { North American Vertical Datum of 1988 } \\ \text { NOAA } & \text { National Oceanic and Atmospheric Administration } \\ \text { PNNL } & \text { Pacific Northwest National Lab } \\ \text { RKM } & \text { River Kilometer } \\ \text { RTK } & \text { Real Time Kinematic } \\ \text { SAV } & \text { Submerged Aquatic Vegetation } \\ \text { SEV } & \text { Sum Exceedance Value } \\ \text { TOC } & \text { Total Organic Carbon } \\ \text { USACE } & \text { United States Army Corps of Engineers } \\ \text { USG } & \text { United States Geological Survey } \\ \text { Water Surface Elevation }\end{array}$





\section{Contents}

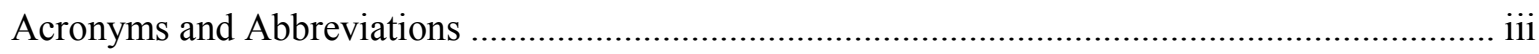

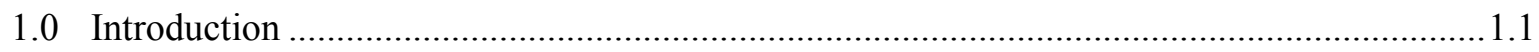

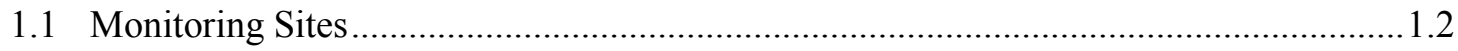

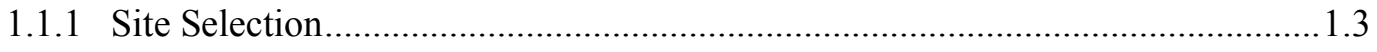

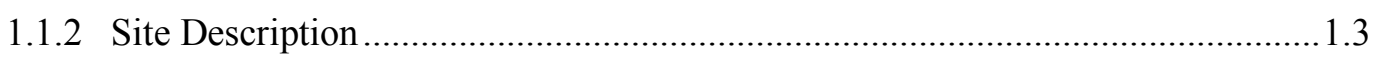

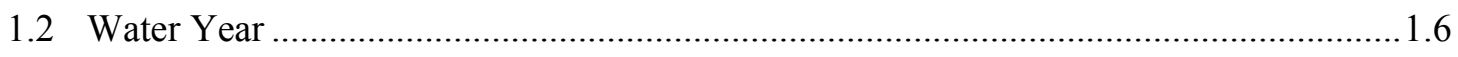

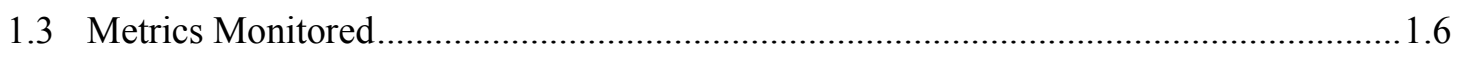

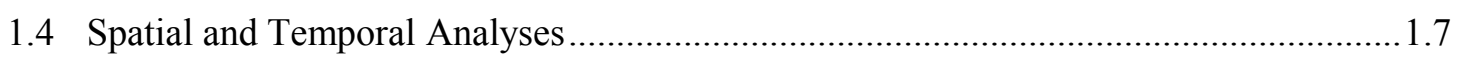

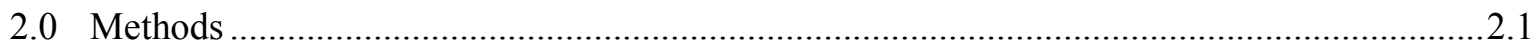

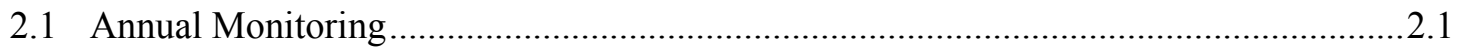

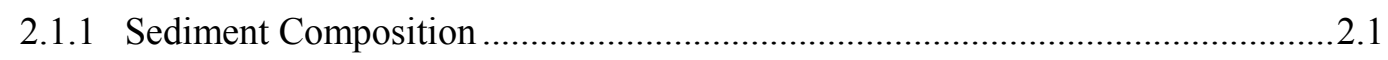

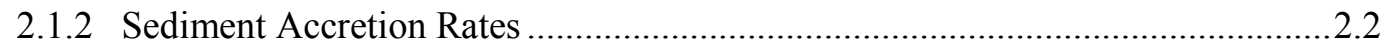

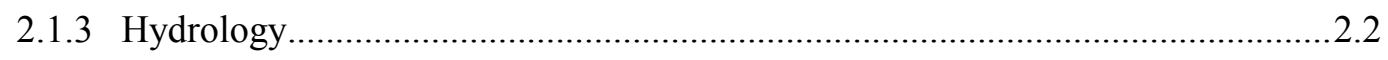

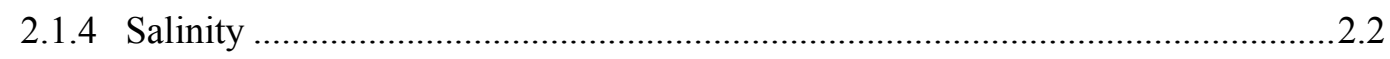

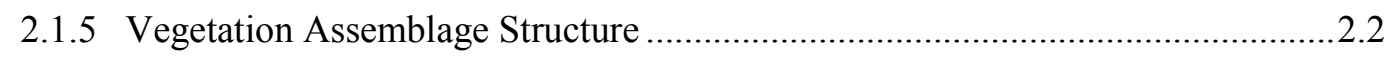

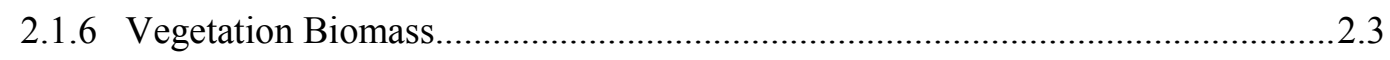

2.1.7 Vegetation Community Mapping ................................................................... 2.3

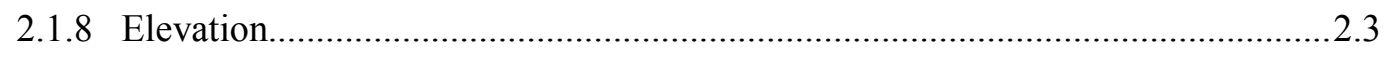

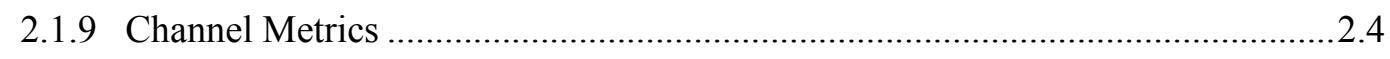

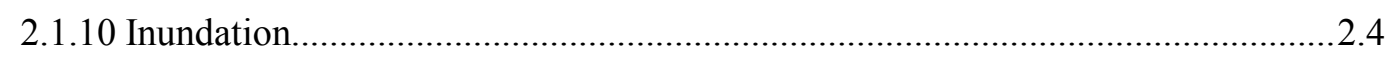

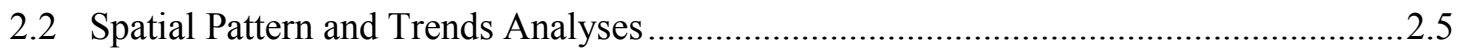

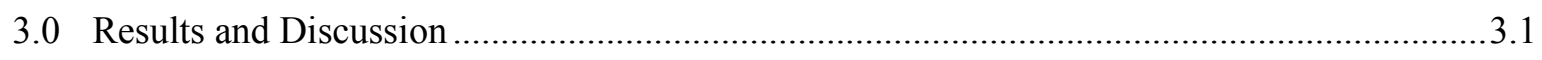

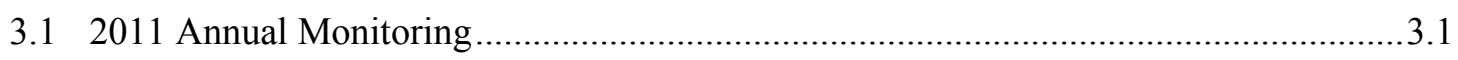

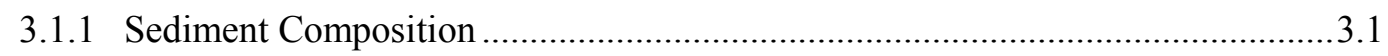

3.1.2 Sediment Accretion Rates ….................................................................. 3.3

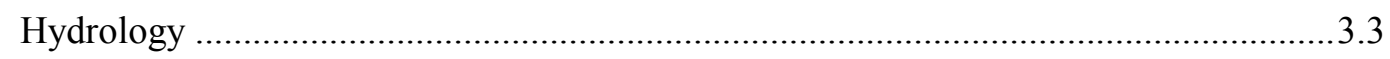

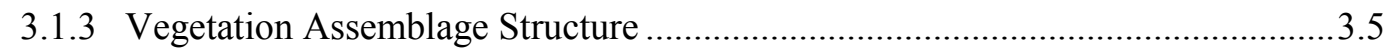

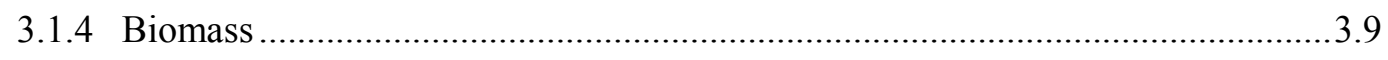

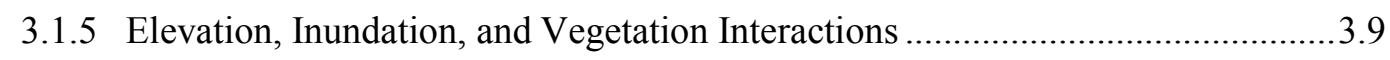

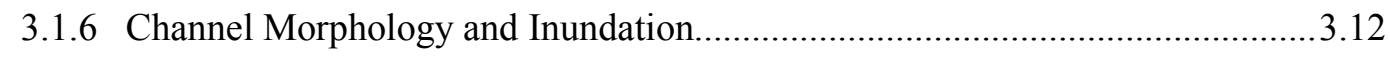

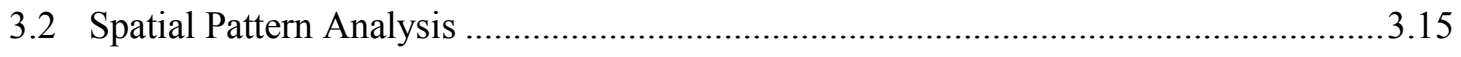

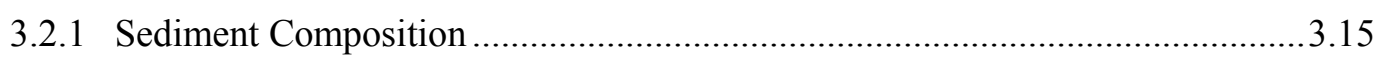

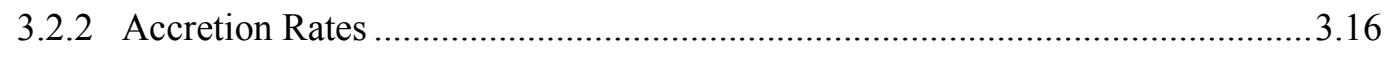

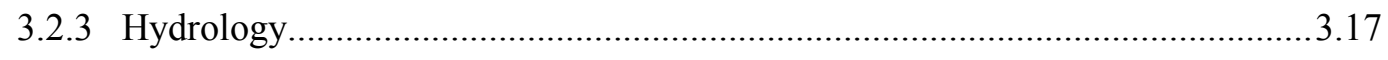

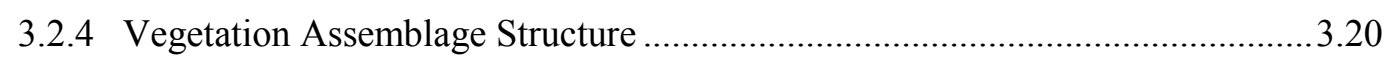

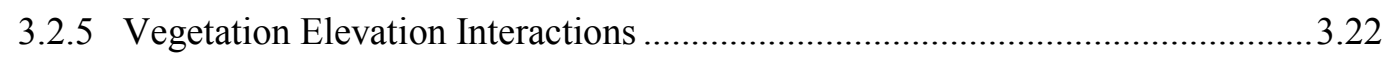


3.2.6 Elevation, Inundation, and Vegetation Interactions ........................................2.25

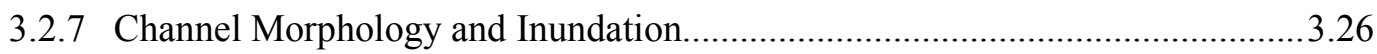

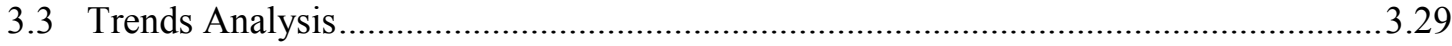

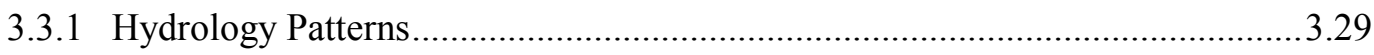

3.3.2 Sediment Accretion Rate.................................................................................2.29

3.3.3 Vegetation and Elevation ...........................................................................

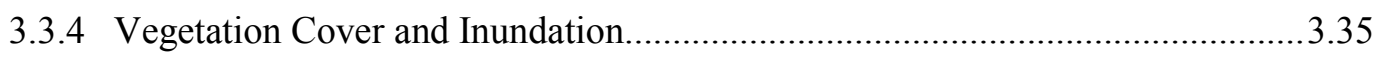

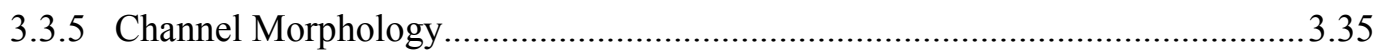

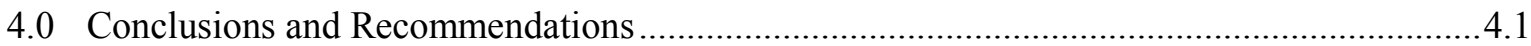

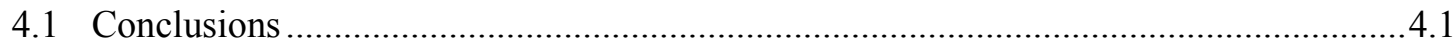

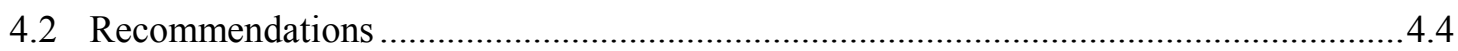

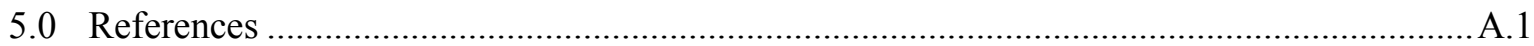

Appendix A - Ecosystem Monitoring Reconnaissance Trip Report ............................................. 1

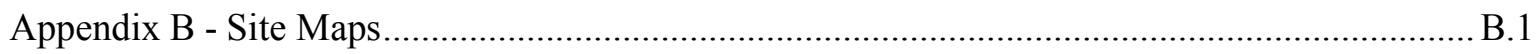

Appendix C - Vegetation Species Cover ….......................................................................... 


\section{Figures}

Figure 1. The Columbia River estuary historical floodplain divided into hydrogeomorphic reaches

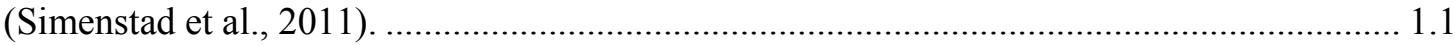

Figure 2. Map of Reaches A to H, showing the location of the 2011 monitoring sites. ................. 1.2

Figure 3. Close-up maps of Reach E depicting historical conditions and the current shoreline......1.4

Figure 4. 2011 Ecosystem Monitoring sites: (a) Baker Bay (near Ilwaco); (b) Whites Island, CutOff Slough; (c) Burke Island slough; (d) Goat Island slough; (e) Deer Island south slough; (f) Cunningham Lake; (g) Campbell Slough; and (e) Franz Lake.......................................... 1.5

Figure 5. Water surface elevation at Bonneville Dam (rkm 233) from August 2010 to August 2011 compared to the 29-year daily average water surface elevation (Data from USGS National Water Information System at: http://waterdata.usgs.gov/nwis/ )............................. 1.6

Figure 6. Grain size (on the left) and total organic carbon (TOC; on the right) at Baker Bay and the Reach E sites.

Figure 7. Water surface elevation data from the study sites where sensors were deployed 20102011. The red line represents the average elevation of the marsh sampling area...................... 3.4

Figure 8. Vegetation species cover and elevations for sites sampled in 2011. Bars represent the minimum and maximum elevations at which the vegetative species occurred within the sample area (See Appendix $\mathrm{C}$ for species names associated with codes along the $\mathrm{x}$-axis). ....3.6

Figure 9. Average elevation of the vegetation survey area (points) with the range of elevations measured in the vegetated survey area (lines).

Figure 10. Percent of time the average marsh elevation was inundated at each site during the deployment period and during the growing season.

Figure 11. Sum Exceedance Values for the 2009-2010 period compared with the 2010-2011 period.

Figure 12. Relative elevations of the channel cross sections for the 2011 sites with multiple cross sections.

Figure 13. Percent total organic carbon (TOC) by strata at historical (top) and created (bottom) marsh sites. Sites are ordered by distance from the LCR mouth, starting at left.

Figure 14. Sediment grain size composition of historical and created marshes, distinguished by strata within the sites. Samples were either taken within the marsh (MA) and channel $(\mathrm{CH})$ strata or separated further into vegetation strata.

Figure 15. Annual sediment accretion and erosion rates for marshes along the river gradient. ....3.17

Figure 16. Inundation frequency and sum exceedence value (SEV) of the average marsh elevation during the total year (TY) and the growing season (GS) at historical sites (top) and created sites (bottom).

Figure 17. Sum exceedance value (SEV) related to elevation for all created and historical marsh sites in the analysis.

Figure 18 Sum exceedance value (SEV) for the growing season related to elevation for created and historical marsh sites within hydrologic zones of the CRE.

Figure 19. Number of species at each site (top) and average percent cover (bottom) of native and non-native species at all marsh sites in the study area.

Figure 20. Frequency of vegetation quadrats at elevations (m, CRD) found in historical and created marshes in this analysis. 
Figure 21. Average and maximum number of species observed at all marsh sites in the study area (top) and maximum number of species at historical and created marsh sites (bottom) by elevation ( $\mathrm{m}, \mathrm{CRD})$

Figure 22. Number of quadrats at each elevation where the common marsh species were observed to have greater than $20 \%$ cover (elevation in meters relative to CRD).

Figure 23. Minimum elevation ( $\mathrm{m}, \mathrm{CRD}$ ) of reed canary grass (Phalaris arundinacea [PHAR]) at sites along the longitudinal gradient of the river. Regression line and 95\% confidence limits (dashed lines) are shown for created and historic marshes above rkm 60 .

Figure 24. Sum exceedance value (SEV) as related to longitudinal gradient of the river (left panel) and total percent vegetation cover related to SEV (right panel).

Figure 25. Average channel depth for the primary marsh channel at historical and created sites included in this analysis.

Figure 26. Inundation frequency at the channel mouth cross-section for the thalweg elevation $(+50 \mathrm{~cm})$ and for the average channel bank elevation $(+10 \mathrm{~cm})$ during the total year $(\mathrm{TY})$ and the peak fish migration period (FW).

Figure 27. Daily mean outflow (red line) at Bonneville dam compared to the 10 -year average (2000-2009; green line) for the years 2005-2011. Note the slightly larger scale for 2011. Data from Columbia River DART website (http://www.cbr.washington.edu/dart/river.html).

Figure 28. Similarity analysis results between years for the four core monitoring sites.

Figure 29. Average percent cover and number of identified species at the core sites for all years monitored.

Figure 30. Lower and upper elevations for the dominant species at the core monitoring sites. Error bars on the 2005-2010 Average bars represent \pm standard deviation.

Figure 31. Annual average percent vegetation cover of the dominant species at a) Cunningham Lake and b) Campbell Slough as related to annual growing season sum exceedance values (SEV) calculated at the average elevation for each species.

Figure 32. Annual average percent vegetation cover of the dominant species at Franz Lake as related to annual growing season sum exceedance values (SEV) calculated at the average elevation for each species.

Figure 33. Elevations of the channel cross sections for the core sites showing multiple years.....3.38 


\section{Tables}

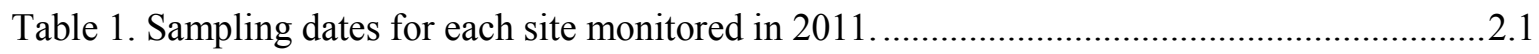

Table 2. Marsh study sites included in spatial patterns analysis..................................................2.7

Table 3. Vegetation strata associated with sediment samples at the 2011 monitoring sites............3.1

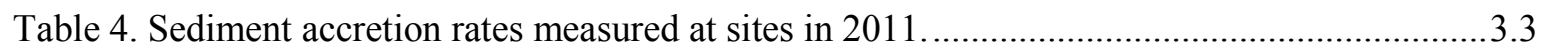

Table 5. Species richness and areal cover of native and non-native species at the 2011 monitoring

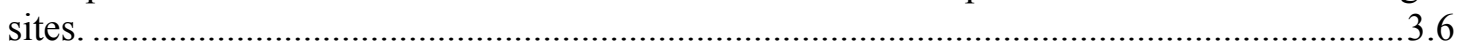

Table 6. Average dry weight per site of emergent and submerged aquatic vegetation biomass for

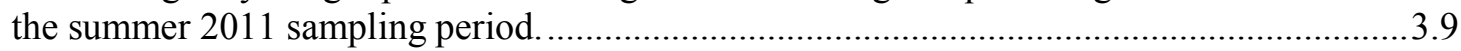

Table 7. Average elevation of vegetation survey areas (relative to CRD) .....................................10

Table 8. Sum exceedance values for the sites where water level data were collected from 2010-

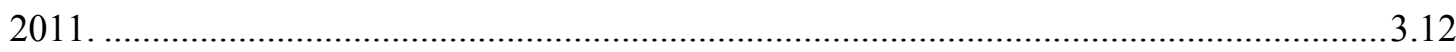

Table 9. Channel metrics and inundation frequencies during the annual deployment period and during the peak juvenile Chinook salmon migration period (March $1^{\text {st }}$ to July $31^{\text {st }}$ ). .*.........14

Table 10. Dominant taxa in terms of percent cover in 37 historical and created marsh sites in the LCRE.

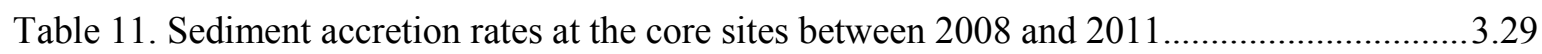





\subsection{Introduction}

The Ecosystem Monitoring Program is a collaborative effort between the Lower Columbia River Estuary Partnership (LCREP), University of Washington, Wetland Ecosystem Team (UW), US Geological Survey, Water Science Center (USGS), National Oceanic and Atmospheric Administration, National Marine Fisheries Service (NOAA-Fisheries, hereafter NOAA), and Pacific Northwest National Laboratory, Marine Sciences Laboratory (PNNL). The goal of the program is to conduct emergent wetland monitoring aimed at characterizing salmonid habitats in the lower Columbia River and estuary (LCRE) from the mouth of the estuary to Bonneville Dam (Figure 1). This is an ecosystem based monitoring program focused on evaluating status and trends in habitat and reducing uncertainties regarding these ecosystems to ultimately improve the survival of juvenile salmonids throughout the LCRE. This project comprehensively assesses habitat, fish, food web, and abiotic conditions in the lower river, focusing on shallow water and vegetated habitats used by juvenile salmonids for feeding, rearing and refugia. The information is intended to be used to guide management actions associated with species recovery, particularly that of threatened and endangered salmonids. PNNL's role in this multi-year study is to monitor the habitat structure (e.g., vegetation, topography, channel morphology, and sediment type) as well as hydrologic patterns.

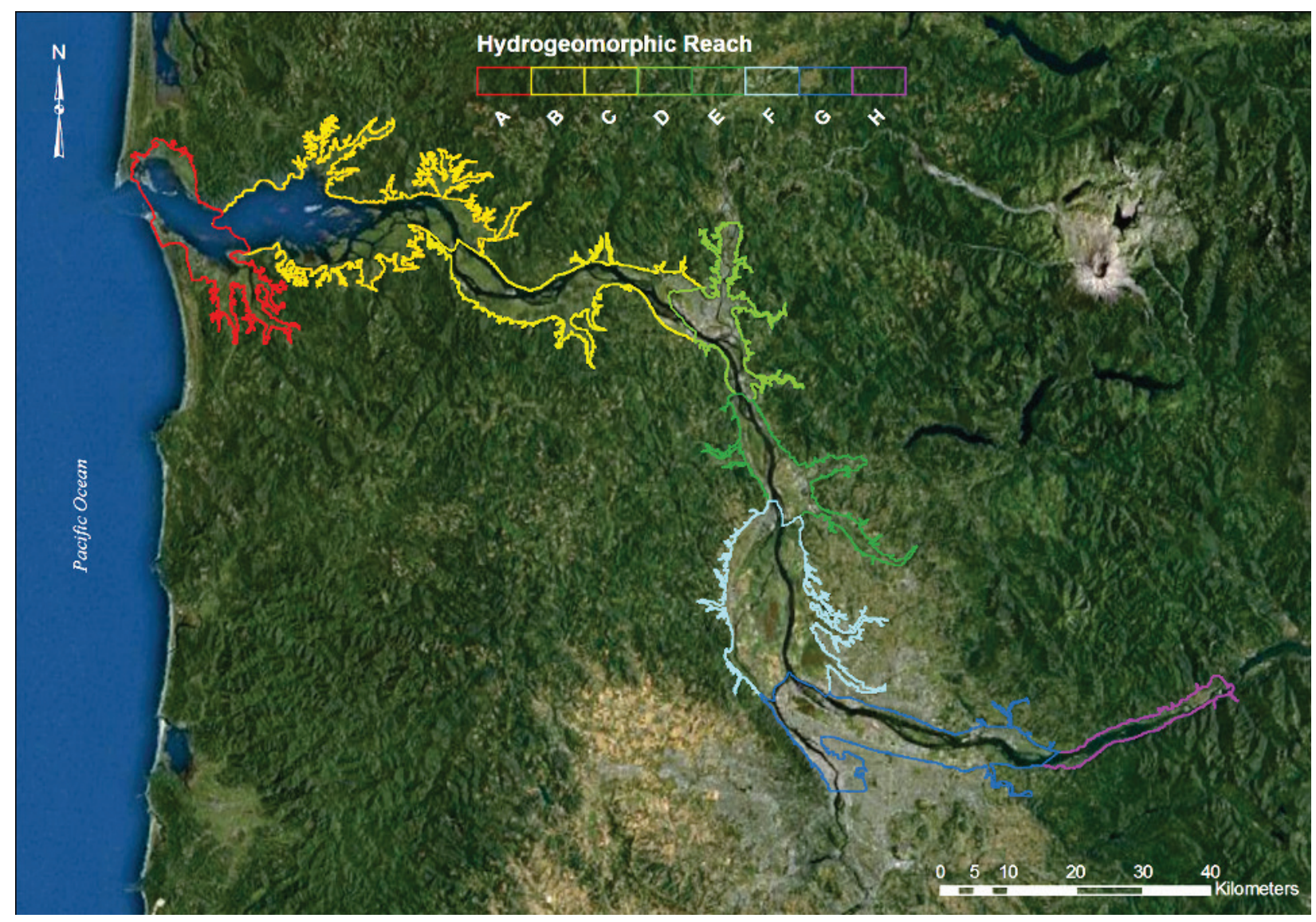

Figure 1. The Columbia River estuary historical floodplain divided into hydrogeomorphic reaches (Simenstad et al., 2011). 
Each year the monitoring program strives to monitor a number of core sites for "trends" analysis and a number of rotating sites for "status" analysis. The number of sites has been limited by available funds in the past, however, the number of core sites has gradually been increasing to allow for a more comprehensive evaluation of the LCRE. To date, 29 sites have been sampled as part of this program. This report summarizes the 2011 field effort and provides the results for multi-site data analysis including data collected at emergent wetland sites from 2005 - 2010 as part of this and other studies in the estuary.

\subsection{Monitoring Sites}

In 2011, PNNL collected field data on vegetation and habitat conditions at a new core site in Reach A, Baker Bay (BBM), near Ilwaco, WA, in addition to previously monitored core sites: one in Reach C (Whites Island, WHC), two in Reach F (Campbell Slough, CS1 and Cunningham Lake, CLM), and one in Reach H (Franz Lake, FLM) (Figure 2). Three new rotating sites in Reach E were also monitored: Burke, Deer and Goat Islands. The sites in Reach F were monitored previously in 2005-2010 and the Reach C site was monitored in 2009 and 2010. The site in Reach H was monitored in 2008 and 2009. Detailed maps of the eight 2011 monitoring sites are presented in Appendix B.

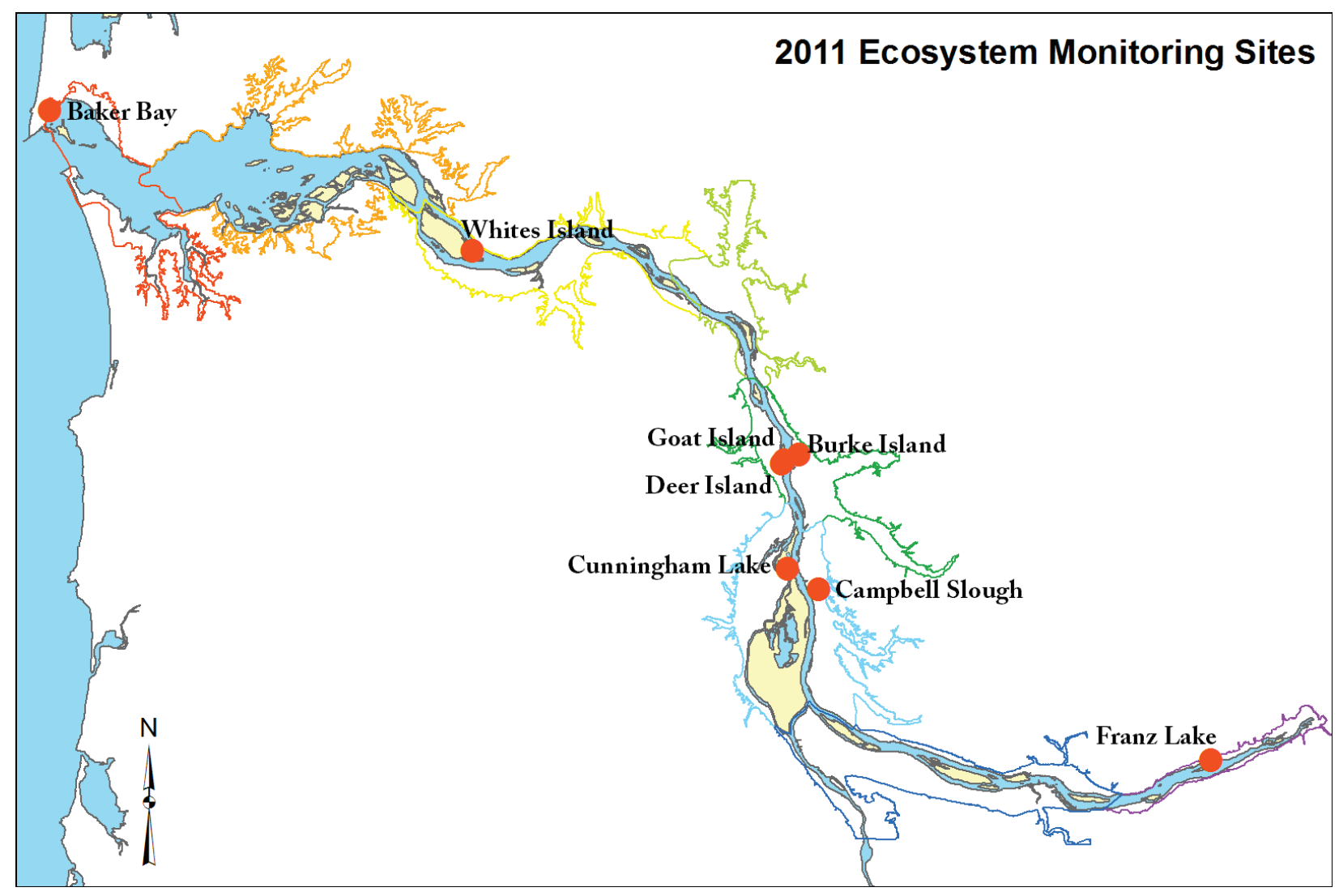

Figure 2. Map of Reaches A to H, showing the location of the 2011 monitoring sites. 


\subsubsection{Site Selection}

A site selection trip took place on November $17-18,2010$ to evaluate the feasibility and appropriateness of potential sites in Reaches D, E, and F and to choose a core site in Reach A (see Appendix A for detailed trip report). Members from each of the monitoring collaborators (PNNL, NOAA, USGS, and LCREP) were present. Prior to the trip, the areas were evaluated using Geographic Information System (GIS) layers including current imagery, LiDAR digital elevation models, and historical maps from the late 1800's. Using these sources of information, the potential sites were narrowed to those that appeared relatively undisturbed and hydrologically connected to the main stem of the Columbia River. Six potential sites were visited in Reaches D and E and all were deemed acceptable for monitoring. Four areas were also visited in Reach A, with two sites accepted in the field assessment.

\subsubsection{Site Description}

Baker Bay. Located in Reach A, southeast of the entrance of Ilwaco harbor, is Baker Bay marsh. The property is currently owned by Washington Department of Natural Resources. Recently selected as a long-term monitoring site, Baker Bay marsh is dominated by lush fields of Lyngby's sedge (Carex lyngbyei) with higher portions occupied by Tufted hairgrass (Deschampsia cespitosa) and cattail (Typha angustifolia). Being so close to the mouth of the river, the slough is regularly inundated with brackish water (Figure 4a).

Whites Island. The Whites Island site is located on Cut-Off Slough at the southern (upstream) end of Puget Island, near Cathlamet, Washington. A portion of the island is owned by Washington Department of Fish and Wildlife (WDFW) and is maintained as Columbia white-tailed deer habitat. Whites Island is not present on the historical maps from the 1880 s and was likely created from dredge material placement. The monitoring site, located at the confluence of a large tidal channel and an extensive slough system, is approximately $0.2 \mathrm{~km}$ from an outlet to Cathlamet Channel; however, according to historic photos, this outlet was not present prior to 2006 and the River connection was approximately $0.7 \mathrm{~km}$ from the monitoring site. The site is characterized by high marsh and a few willows, with numerous small tidal channels.

Burke Island, Goat Island, and Deer Island. Three rotating sites for this sampling year occur in Reach E. Burke Island slough, located furthest downstream at river kilometer 131, is the only historically present marsh of the three (Figure 3). Located on private property, the slough and associated marsh are wedged between agriculturally managed fields. The Burke Island marsh consists mostly of wapato (Sagittaria latifolia) and sparse reed-canary grass (Phalaris arundinacea), with the reed-canary grass becoming more dense in the higher areas. Located across the river on the Oregon side is Goat Island slough, a created site composed of dredge material deposited within the last 50 years. The monitoring site, located at the upstream end of the island, is a fringing emergent marsh surrounded by steep banks populated by cottonwood (Populus balsamifera) and Pacific willow (Salix lucida). Adjacent to the Goat Island slough is Deer Island south slough, which hugs the Oregon bank. The lower portion of the site is dominated by sparse creeping spike-rush (Eleocharis palustris) and sparse reed-canary grass (Phalaris arundinacea), with reed-canary grass becoming more dense in the higher areas. 


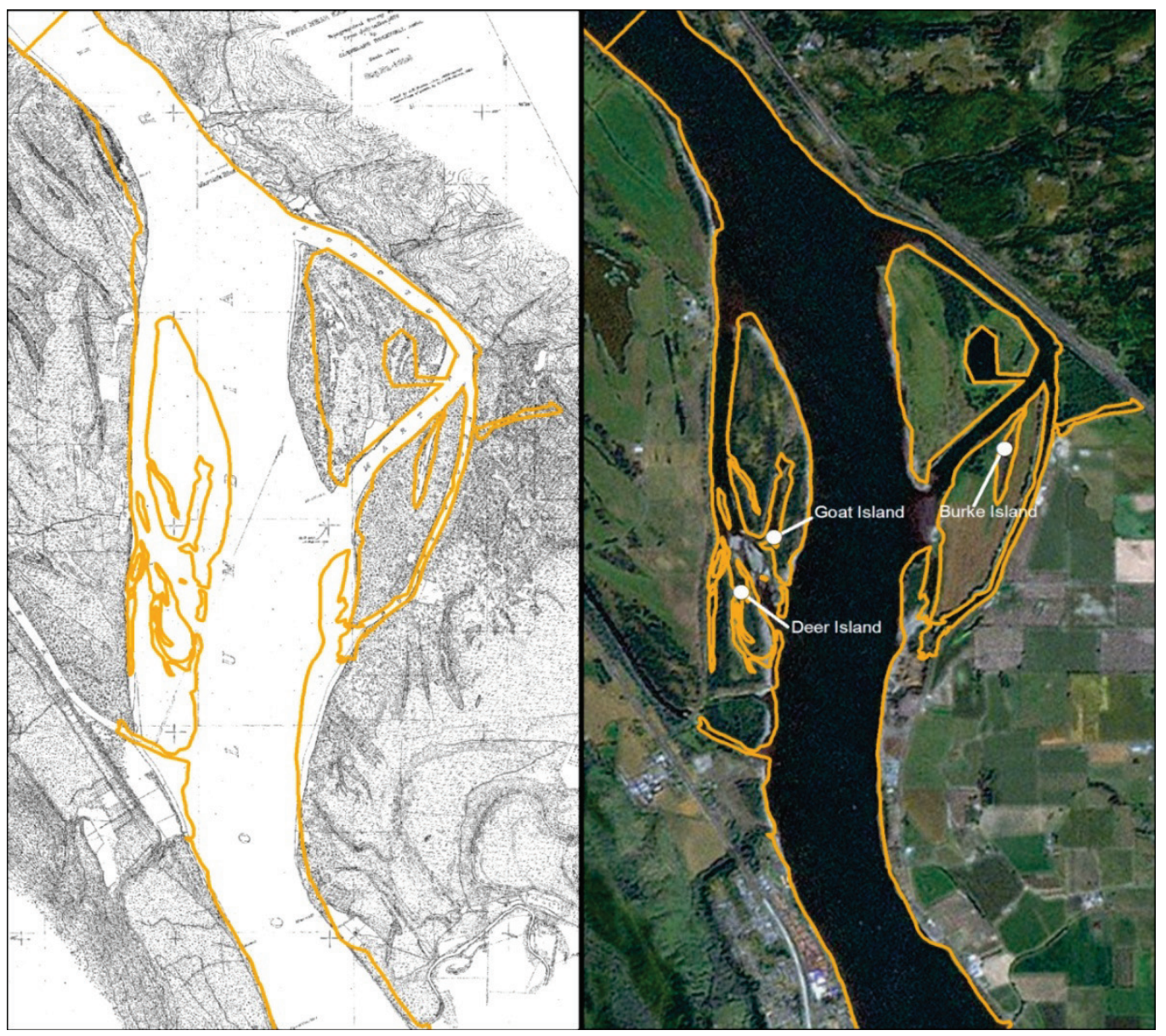

Figure 3. Close-up maps of Reach E depicting historical conditions and the current shoreline.

Cunningham Lake and Campbell Slough. Cunningham Lake and Campbell Slough sites are located in Reach F. These sites have been surveyed annually since 2005. While the 2004 rotational-panel sampling design has never be fully implemented due to program funding levels, these two sites have been included with each annual survey to help better understand inter-annual variability in vegetation patterns. Cunningham Lake is located on Sauvie Island in the Oregon DFW Wildlife Area at the end of Cunningham Slough, approximately $6.4 \mathrm{~km}$ from the mainstem of the Columbia River. The site is a fringing emergent marsh bordering the extremely shallow "lake" (Figure 4f) that in some years is covered with wapato (Sagittaria latifolia). Campbell Slough is located on the Ridgefield National Wildlife Refuge in Washington. The monitoring site is an emergent marsh adjacent to the slough, approximately $1.4 \mathrm{~km}$ from the mainstem of the Columbia River. The site grades from wapato up to reed canary grass and is adjacent to fenced-in pasture land. Extensive grazing occurred at the site in 2007 but vegetation has been recovering since then. In 2010 and 2011, slight evidence of grazing was again observed.

Franz Lake. Located the furthest up river in Reach $\mathrm{H}$ is Franz Lake, which is part of the Pierce National Wildlife Refuge. The site has an expansive area of emergent marsh extending $2 \mathrm{~km}$ from the mouth of the slough to a large, shallow ponded area. The sample site was located approximately $350 \mathrm{~m}$ from the channel mouth. Several beaver dams have created a series of ponds along the length of the channel resulting in large areas of shallow-water wetland with fringing banks gradually sloping to an upland ecosystem. 

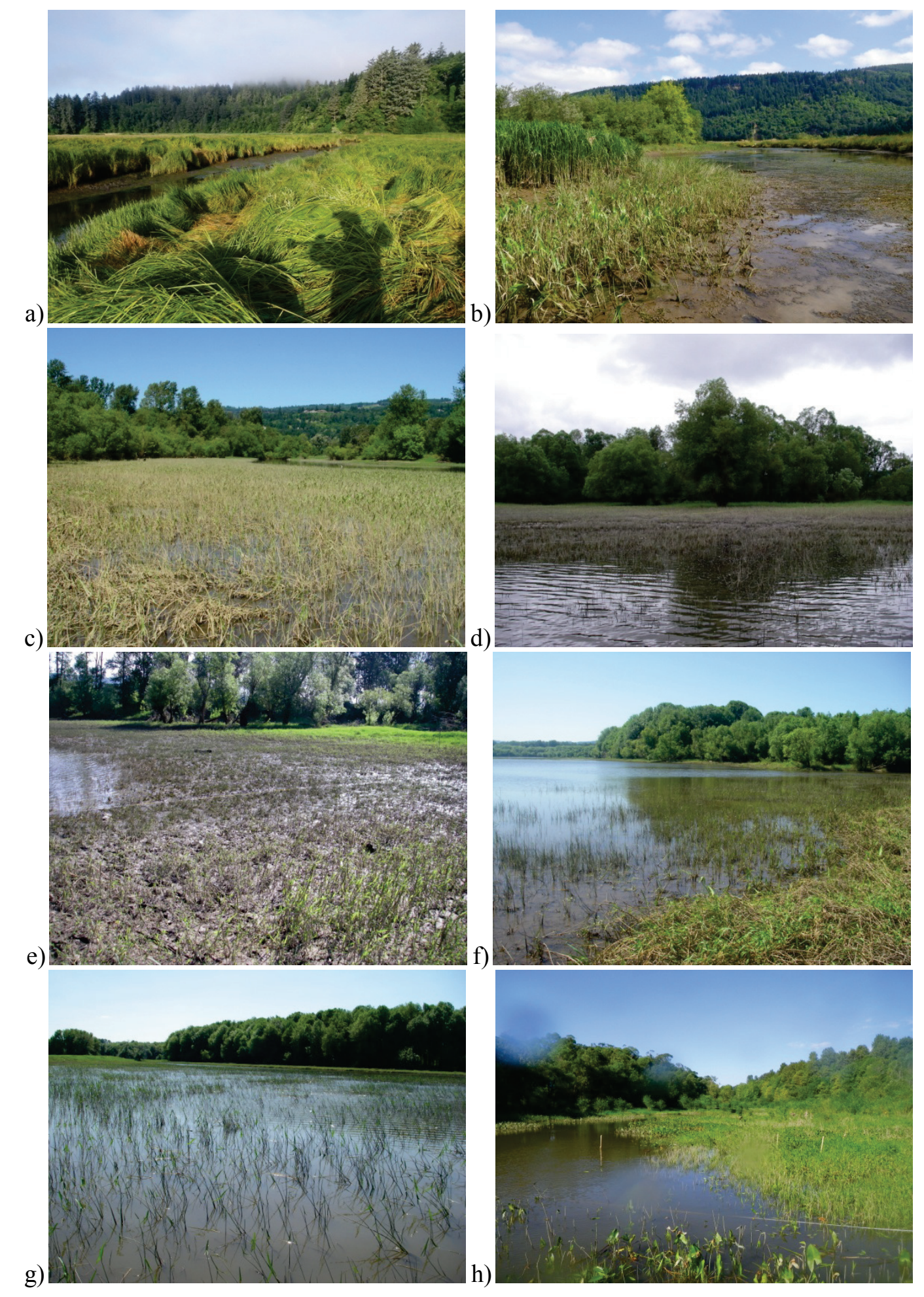

d)

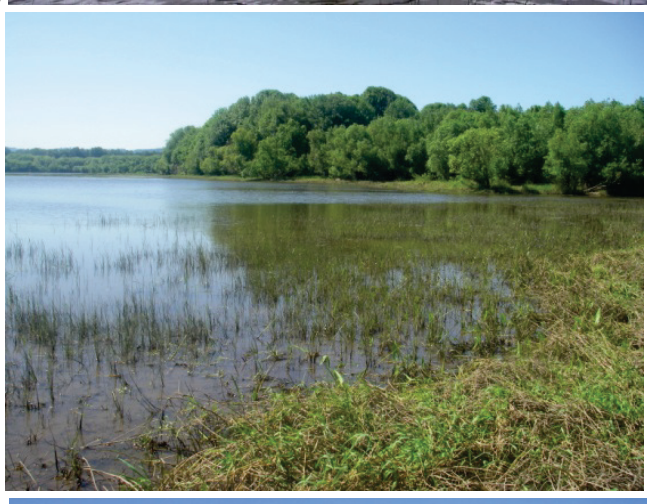

h)

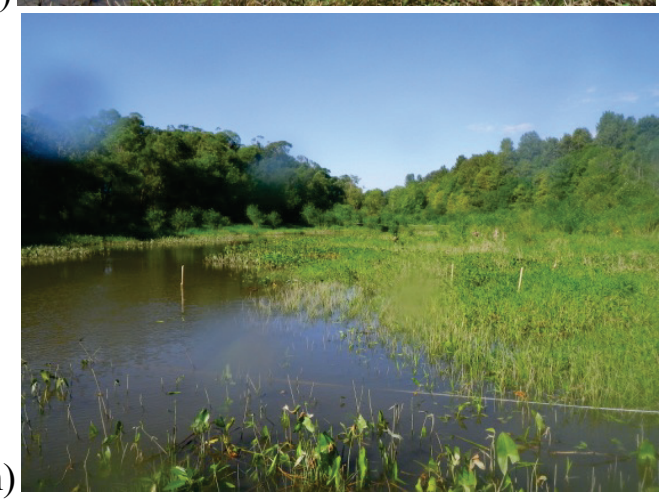

Figure 4. 2011 Ecosystem Monitoring sites: (a) Baker Bay (near Ilwaco); (b) Whites Island, Cut-Off Slough; (c) Burke Island slough; (d) Goat Island slough; (e) Deer Island south slough; (f) Cunningham Lake; (g) Campbell Slough; and (e) Franz Lake. 


\subsection{Water Year}

The water year from 2010 to 2011 began with the water surface elevation (WSE) below average in the fall followed by above average water levels through the spring and summer (Figure 5). The WSE resulting from the spring freshet in 2011 was $2.5 \mathrm{~m}$ higher than the 29 -year average, starting with a peak in early April then sustained at that level or higher from mid-May to mid-July. During our usual sampling period in the last 2 weeks of July, WSE was still higher than average and precluded sampling at any 2011 monitoring sites until late July, and at the Franz Lake site (nearest the dam at river kilometer [rkm] 221) until late August. Even at these late dates, water was present in the vegetation at all sites during sampling, and at some lower elevation areas the water was too deep to see the bottom.

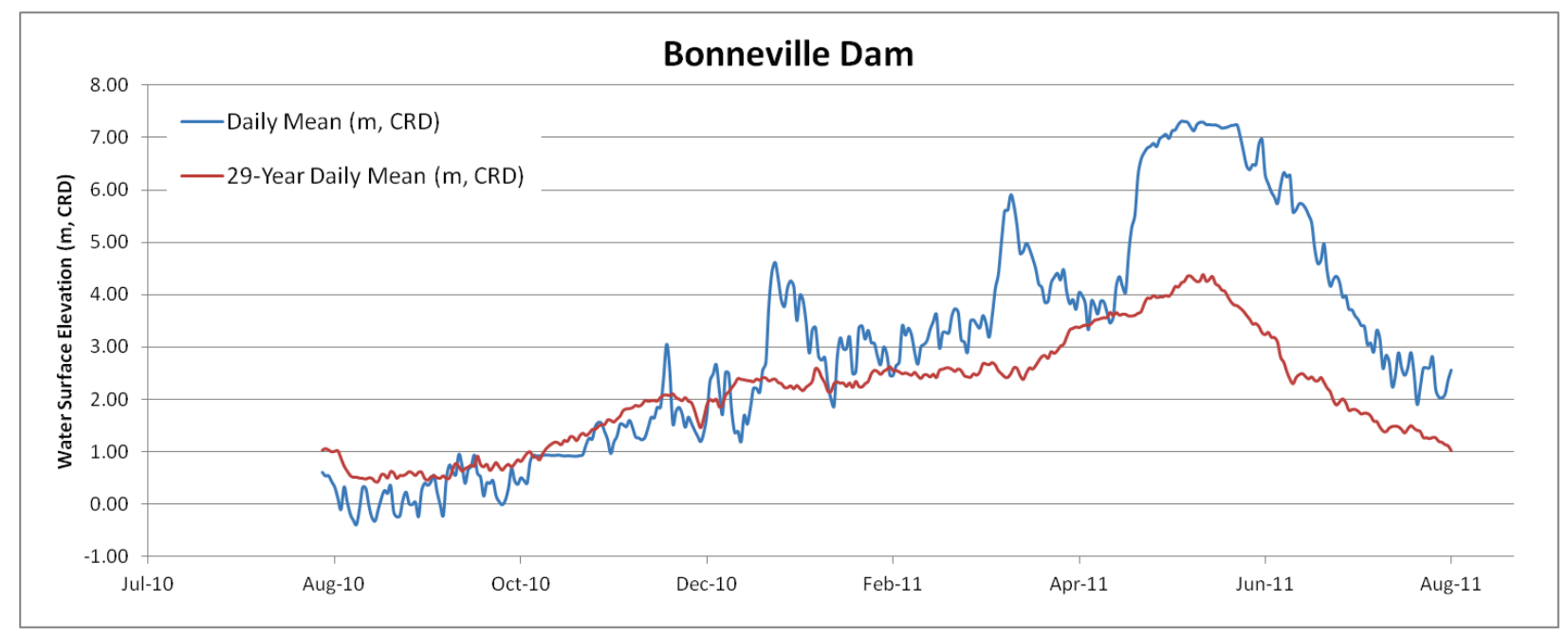

Figure 5. Water surface elevation at Bonneville Dam (rkm 233) from August 2010 to August 2011 compared to the 29-year daily average water surface elevation (Data from USGS National Water Information System at: http://waterdata.usgs.gov/nwis/ ).

\subsection{Metrics Monitored}

This study is using standard monitoring protocols developed for the LCRE (Roegner et al., 2009). Five metrics are included in this part of the monitoring program. These metrics have been determined to represent important structural components, which can be inferred to provide habitat functions. The rationale for choosing these metrics is discussed below.

Elevation, hydrology, and substrate are the primary factors that control wetland vegetation composition, abundance, and cover. Knowing the elevation, soil, and hydrology required by native tidal wetland vegetation is critical to designing and evaluating the effectiveness of restoration projects (Kentula et al., 1992). Sediment accretion is important for maintaining wetland elevation. Accretion rates can vary substantially between natural and restored systems (Diefenderfer et al., 2008); therefore, baseline information on rates is important for understanding potential evolution of a reference or restoration site. Evaluating vegetation composition and species cover provides an indication of the many functions provided by wetland vegetation. These functions include the production of organic matter (macrodetritus), food web support, habitat for many fish and wildlife species including salmon, and contributing to overall biodiversity of the Columbia River estuarine ecosystem. Likewise, collection of vegetation biomass is 
being conducted at the core sites to begin to quantify the contribution of organic matter from these wetlands to the ecosystem.

Assessment of channel cross sections and channel networks provides information on the potential for many important estuarine functions including fish access (Simenstad and Cordell 2000) and export of prey, organic matter, and nutrients. This information is also necessary to develop the relationship between cross-section dimensions and marsh size, which aids in understanding the channel dimensions necessary for a self-maintaining restored area (Diefenderfer et al., 2009). The primary objective associated with the channel data collection effort is to determine how unmodified channels may differ between reaches within the region with regard to habitat opportunity (Bottom et al., 2005).

\subsection{Spatial and Temporal Analyses}

One of the primary goals of the Ecosystem Monitoring program is to evaluate status and trends of wetland ecosystems in the LCRE. Each year we evaluate the status of a number of sites, characterizing their habitat structure, and we have begun to analyze data collected over the past seven years to evaluate trends. We initiated the analysis of trends over time in 2010 (Borde et al 2011b) and continued this year with the addition of a spatial pattern analysis. The primary questions on which the spatial pattern analysis is focused are as follows:

1) Are there differences in the wetland vegetation species assemblages along the estuarine gradient?

2) Are there patterns in the elevation ranges of vegetation communities throughout the estuary?

3) Is there a discernible lower elevation limit of reed canary grass (Phalaris arundinacea) in the estuary?

4) What are the patterns of hydrologic inundation and how do they vary in the estuary?

5) Are the inundation patterns in the estuary related to variations in vegetation communities?

6) How do wetland channels vary along the estuarine gradient?

In order to better analyze these questions, we included all available data from relatively undisturbed emergent wetland sites collected between 2005 and 2010. These data were collected through a variety of programs funded by the Bonneville Power Administration (BPA) and the US Army Corps of Engineers (USACE); in all, 37 sites were analyzed (see Section 2.2 for details). 



\subsection{Methods}

The methods outlined below detail 1) the annual monitoring methods employed at the core and rotational sites; 2) the methods used to synthesize data collected since 2005 at multiple monitoring sites; and 3) the methods used to update the temporal analysis of the core sites that was originally conducted in 2010 (Borde et al., 2011a)

\subsection{Annual Monitoring}

As in previous years (i.e., 2005-2010), we surveyed sites for elevation, determined percent cover of vegetation along transects, and mapped prominent vegetation communities within the marsh. Since 2009, we have also measured channel cross sections, installed sediment accretion stakes at all sites, and collected sediment samples at new sites. New in the 2011 sampling year, biomass collection was performed at all of the core sites, excluding Cunningham Lake. A photo point was also designated at each site from which photographs were taken to document the 360-degree view. Methods generally follow the restoration monitoring protocols developed by Roegner et al. (2009) for the LCRE.

The vegetation monitoring schedule was delayed this year by an extended high water period (see Section 1.2 above). Biomass retrieval was also delayed at Campbell Slough, as was all vegetation monitoring at Franz Lake. The high water also influenced several of the metrics recorded, including vegetation percent cover. At the upper river sites, lower portions of the marshes were inundated during the entire monitoring period. Sampling occurred between 7/26/2011 and 8/26/2011 (Table 1).

Table 1. Sampling dates for each site monitored in 2011.

\begin{tabular}{lc}
\hline Site & Sampling Date \\
\hline Goat Island & $7 / 26 / 2011$ \\
\hline Deer Island & $7 / 27 / 2011$ \\
\hline Burke Island & $7 / 28 / 2011$ \\
\hline Campbell Slough & $7 / 29 / 2011^{*}$ \\
\hline Cunningham Lake & $7 / 30 / 2011$ \\
\hline Baker Bay & $8 / 1 / 2011$ \\
\hline Whites Island & $8 / 2 / 2011$ \\
\hline Franz Lake & $8 / 25 / 2011$ \\
\hline * The biomass samples at Campbell Slough were collected on $8 / 26 / 11$.
\end{tabular}

\subsubsection{Sediment Composition}

Sediment samples were collected within each major vegetation community strata at Baker Bay, Burke Island, Deer Island and Goat Island. Sediment samples were collected in 2008 at Campbell Slough and Cunningham Lake, and at Franz Lake and Whites Island in 2009 and therefore were not recollected this year. Two $10-\mathrm{cm}$ cores were collected within each stratum and homogenized in a large metal bowl, placed in a clean plastic bag, and kept in a cooler until shipment to the analyzing lab. Samples were analyzed by Columbia Analytical Services in Kelso, Washington for total organic carbon (TOC) 
following the ASTM D4129-82M method and grain size following PSEP (1986) methods. Samples were analyzed within 17 days from the time of collection.

\subsubsection{Sediment Accretion Rates}

At each site, PVC stakes separated by one meter were driven into the sediment and leveled. The distance from the plane at the top of the stakes to the sediment surface is measured as accurately as possible every $10 \mathrm{~cm}$ along the one meter distance. The stakes are measured at deployment and again, one year later at recovery. The stakes, termed sedimentation stakes, are used to determine gross annual rates of sediment accretion or erosion (Roegner et al., 2009). Sedimentation stakes are measured annually at each of the core sites and were installed and measured at the Burke, Deer and Goat Islands sites this year, where they will be measured and retrieved in 2012. The accretion or erosion rate is calculated by averaging the 11 measurements from each year and comparing the difference.

\subsubsection{Hydrology}

In 2010, pressure transducers (HOBO Water Level Data Loggers, Onset Computer Corporation) were deployed at each of the core sites as a means of logging in situ water level data for one year. Sensors were redeployed at Whites Island, Cunningham Lake, Campbell Slough and Franz Lake in the summer of 2010. During the fall of 2010, a sensor was deployed at Baker Bay that turned out to be faulty, and was replaced in April 2011. For the Reach E sites, sensors were deployed at Burke and Goat Islands in July 2011 and will be retrieved during the summer of 2012. The sensor at Goat Island will also be used for Deer Island.

\subsubsection{Salinity}

In order to better assess the influence of salinity on habitat, a conductivity data logger (Onset Computer Corporation) was deployed at the Baker Bay site in August of 2011. The data logger will be recording conductivity and temperature within the slough and deriving salinity on-the-fly from those two measurements, based on the Practical Salinity Scale of 1978 (see Dauphinee 1980 for description of conversion).

\subsubsection{Vegetation Assemblage Structure}

The vegetation sample areas at each site were selected to be near a tidal channel and to be representative of the elevations and vegetation communities present at the site. This was easier in the upper portions of the estuary, where the sites were generally narrower and the entire elevation range could be easily covered in the sample area. In the lower estuary, the sites were broad and covered a larger area, so in some cases multiple sample areas were surveyed if possible to cover different vegetation communities (e.g., low marsh and high marsh).

Along each transect, vegetative percent cover was evaluated at 2-5 meter intervals. Interval length was based on the transect length and/or the vegetation homogeneity. At each interval on the transect tape, a $1-\mathrm{m}^{2}$ quadrat was placed on the substrate and percent cover was estimated by observers in $5 \%$ increments. If two observers were collecting data then they worked together initially to ensure their observations were "calibrated." Species were recorded by four letter codes (1st two letters of genus and 
1st two letters of species, with a number added if the code had already been used, e.g., LYAM is Lysichiton americanus and LYAM2 is Lycopus americanus). In addition to vegetative cover, features such as bare ground, open water, wood, and drift wrack were also recorded. When plant identification could not be determined in the field, a specimen was collected for later identification using taxonomic keys or manuals at the laboratory. If an accurate identification was not resolved, the plant remained "unidentified" within the database. Where visibility through the water column allowed, the degree of submerged aquatic vegetation coverage was estimated to the extent possible by the observers.

\subsubsection{Vegetation Biomass}

Beginning this year, above ground biomass was sampled to estimate the primary productivity at the core sites. For the emergent marsh biomass sampling, a 1-m square plot was randomly placed along the established vegetation transect, making sure that the biomass plots did not intersect the vegetation percent cover plots, with two biomass plots evenly spaced per transect. Within the 1-m square biomass plot, a 0.1 $\mathrm{m}^{2}$ quadrat was placed in a randomly selected corner and all rooted vegetation, live or dead, was removed using shears. Each sample was placed in a uniquely numbered bag, and held in a cooler for the remainder of the sampling trip. For the submerged aquatic vegetation (SAV) plots, similar methods were employed with the exception of the placement of the plots. Either existing transects were extended past the baseline or new transects were created to reach the main slough. In some instances, an existing transect intersected the slough and an SAV plot was randomly placed along it. Depending on the width of the channel, either one or two SAV plots were randomly placed along each transect. Vegetation species were recorded in field notebooks along with the corresponding biomass sample number. In the laboratory, the biomass samples were stored in a cold room until processing could begin. The samples were then individually rinsed of all non-organic material, and obvious root material was removed. Pre-weighed pieces of tinfoil were used to secure the individual biomass samples, a wet weight was then measured, and the samples were placed in an oven set at $90^{\circ} \mathrm{C}$ for three to four days. When the samples were deemed completely dry, a second weight was then measured for each sample, and entered either into a datasheet or directly into a spreadsheet software program.

\subsubsection{Vegetation Community Mapping}

Using Trimble GeoXT and GeoXH handheld global positioning system (GPS) units, a representative portion of each site (using reasonable natural boundaries) was mapped and major vegetation communities were delineated within the site. Additionally, features of importance to the field survey (e.g., transect start/end points, depth sensor location, and photo points) were also mapped. All data were input to a GIS, and maps of each site showing major communities and features were created (Appendix B).

\subsubsection{Elevation}

At all sites, elevation was measured at each of the following locations: vegetation quadrats, the water level sensor, sediment accretion stakes, vegetation community boundaries, and in the channels. Elevation was surveyed using a Trimble real time kinematic (RTK) GPS with survey-grade accuracy. All surveying was referenced to the NAVD88 vertical datum; horizontal position was referenced to NAD83. Data collected from the base receiver were processed using the automated Online Positioning User Service (OPUS) provided by the National Geodetic Survey. OPUS provides a Root Mean Squared (RMS) value for each set of static data collected by the base receiver, which is an estimate of error. A local surveyed 
benchmark was located whenever possible and measured with the RTK to provide a comparison between the local benchmark and OPUS derived elevations.

Trimble Geomatics Office (TGO) software was used to process the data. Each survey was imported and overviewed by a scientist. Benchmark information was entered into TGO and rover antenna heights were corrected for disc sink (measured at each survey point to the nearest centimeter) at each point. The survey was then recomputed within TGO and exported in a GIS shapefile format. Surveys were visually checked within TGO and GIS software for validity. Elevations were then converted from NAVD88 to the Columbia River Datum (CRD) based on conversions developed by the USACE (unpublished). Using the CRD alleviates elevation differences associated with the increasing elevation of the river bed in the landward direction. Sites below RKM 37, the lower limit of the CRD, were converted to mean lower low water (MLLW).

All survey notes were recorded on data sheets during site visits, and subsequently transferred into Microsoft Excel at the laboratory. Quality assurance checks were performed on $100 \%$ of the data entered. Elevations from the RTK survey were entered into the Excel spreadsheet to correspond to the appropriate transect and quadrat location. All elevations in this report are referenced to CRD unless noted otherwise.

\subsubsection{Channel Metrics}

Elevation surveys were conducted for channel cross-sections at all sites. Five channel cross-sections were surveyed at most sites starting near the mouth of the channel and continuing past the marsh vegetation survey area. The mouth of the channel is described as the point where the vegetated banks start. Channel cross-sections were distributed evenly along the channel. Exceptions were made where a major side-channel met with the main channel. In these cases, the cross-section was moved above the confluence. Site maps identify the locations of all cross-sections (Appendix B). Additional notes were made for features of interest located at the cross-section: top and bottom of bank, vegetation edges, and thalweg. Data from the elevation surveys were used to calculated channel depth. The elevation data were also combined with hydrology data to calculate inundation times for the channel and bank edge (see Section 2.5).

\subsubsection{Inundation}

The data from the water level sensors were used to calculate inundation metrics from the marsh and channel elevations collected at those sites. Inundations were calculated for only the core sites, with the exception of Franz Lake, where the sensor could not be found at the time of retrieval because of beaver activity. Due to the faulty sensor at Baker Bay, inundation metrics were only calculated from April 2011 to August 2011.

The percent of time each marsh was inundated was calculated for the entire period of record (approximately one year) and for the growing season, April 22-October 12. The growing season is based on the number of frost-free days for the region, as determined by the Natural Resource Conservation Service (NRCS) in the wetland determination (WETS) table for Clark County, WA (NRCS 2002). The Clark County growing season is used for all the sites in the estuary so that the inundation calculations are standardized to one period. The inundation frequency during the growing season was only calculated during daylight hours (between 0900 and 1700). This limitation was employed primarily for tidal areas 
where the timing of the daily high tide can be a factor in the amount of time available for plants to photosynthesize.

The percent of time each channel was inundated was calculated for the thalweg and top-of-bank elevations and for two time periods. In order to estimate habitat opportunity for juvenile salmonids, water depth of $50 \mathrm{~cm}$ was added to the thalweg elevation of each cross-section as an indicator of the amount of water adequate for fish use of the channel (Nicole Sather, personal communication). Likewise, a 10cm water depth was added to the top of bank elevation at each cross-section to represent a minimum amount of water needed for fish to access the vegetation at the edge of the bank (Bottom et al., 2005; Kurt Fresh personal communication). The periods assessed were 1) the deployment period (generally July to July) and 2) the period from March 1 through July 31, which represented the peak juvenile Chinook migration period as determined from data collected as part of this Ecosystem Monitoring Program and other studies (Bottom et al., 2005; Sather et al., 2011).

In order to better assess hydrologic patterns and to make sites comparable over time and space, we needed a single measurement that would incorporate magnitude, timing, and duration of surface water flooding. Following work conducted in the US and in Europe (Gowing et al., 2002; Simon et al., 1997; Araya et al., 2010) we calculated the sum exceedance value (SEV) using the following equation:

$$
\mathrm{SEV}=\sum_{i=1}^{n}\left(d_{\text {elev }}\right)
$$

where $n$ is the number of hours present in the time period evaluated, and $d_{\text {elev }}$ is the hourly water surface elevation above the average marsh elevation. This differs from previous LCRE studies (Borde et al., 2011a and Borde et al., 2011b) in which the daily mean water surface elevation was used in the calculation rather than the hourly water level elevation used here. The latter was chosen to ensure we captured daily inundation fluctuations that occur in the more tidally dominated sites. The time periods evaluated were the annual deployment period and the growing season. Both periods were standardized to include the same days in each year, as follows:

Growing season: April 22 to June 21 and August 20 to October 12 (115 days)

Annual deployment period: August 20 to June 21 (of the next year; 306 days)

This standardization was necessary because in the past, the deployment and retrieval dates for sensors varied between June 21 and August 20 and to compare calculations from past and present data required that the same time periods be used.

\subsection{Spatial Pattern and Trends Analyses}

In order to compare marsh habitats throughout the estuary, we combined the datasets on the structural habitat metrics from multiple programs. Structural habitat data from relatively undisturbed emergent marshes between Reaches $\mathrm{C}$ and $\mathrm{H}$ have been collected as part of this study since 2005. Additionally, similar data from multiple undisturbed habitat types, including marshes, were collected throughout the LCRE as part of the Reference Site Study (Borde et al., 2011a) and the Cumulative Ecosystem Response to Restoration Study (Johnson et al., 2011 between 2005 and 2010. Finally, data from three marsh sites in Reach $G$ that were part of the Tidal Freshwater Monitoring program (Johnson et al., 2011) were also included in the analysis, bringing the total number of sites analyzed to 39 (Table 2). 
The term "historical class" (Table 2) refers to two categories that can be applied to the marsh sites to provide context for their ages and disturbance histories, defined as follows:

Historical: $\quad$ Sites present on the historical maps from the late 1800's.

Created: $\quad$ Sites that were not present on the historical maps and have been created from modified sediment and hydrologic processes and placement of dredge material.

All data included in this analysis was collected according to the LCRE Restoration Monitoring Protocols (Reogner et al., 2009). Below are brief descriptions of the methods used to analyze temporal and spatial trends in the data.

A multi-year analysis was conducted as part of this program in 2010 and included data from two sites (CLM and CS1) that had been monitored from 2005-2009 and one site (FLM) from 2008-2009 (Borde et al., 2011b). This analysis included the calculation of inundation (SEV) and vegetation cover. We updated these calculations using data from 2010 and 2011 and adding an additional site (WHC) that had been monitored from 2009-2011. The SEV was calculated using the method established in the previous analysis where data from the nearest long-term water level station (in the main stem of the River) was modified using regression analysis with the onsite data. In the updated analysis we also evaluated interannual changes channel morphology in locations where channel cross sections had been measured in multiple years and sediment accretion rates where available.

In this year's trend analysis, we also included a similarity analysis of the vegetation species assemblage and cover. Similarity analyses, using the Bray-Curtis similarity coefficient (S') as a measure of distance between years (described in Clarke and Warwick, 2001), were performed on percent cover data from each site by using Primer ${ }^{\mathrm{TM}}$. Percent cover data were arc-sin, square-root transformed, but were not standardized, prior to analyses. The similarity matrix was converted to a dendrogram by using the hierarchical, unweighted pair-group mean-averaging method of clustering. Clusters combined at greater linkage distance are more dissimilar than those combined at smaller linkage distances. 
Table 2. Marsh study sites included in spatial patterns analysis.

\begin{tabular}{|c|c|c|c|c|c|}
\hline Site Name & $\begin{array}{l}\text { Site } \\
\text { Code }\end{array}$ & $\begin{array}{l}\text { Distance from } \\
\text { Col. River } \\
\text { mouth (rkm) }\end{array}$ & Reach & $\begin{array}{l}\text { Monitoring } \\
\text { Year }\end{array}$ & $\begin{array}{l}\text { Historical } \\
\text { Class }\end{array}$ \\
\hline Chinook River, mouth* & $\mathrm{CHM}$ & 12 & A & 2009 & historical \\
\hline Lewis \& Clark River, mouth & LCM & 20 & A & 2009 & historical \\
\hline Cooperage Slough & CSM & tributary & A & 2007 & historical \\
\hline Grant Island & GIM & tributary & A & 2009 & historical \\
\hline Secret River* & SRM & 37 & B & 2008 & historical \\
\hline Miller Sands & MSC & 39 & B & 2009 & created \\
\hline Welch Island & WIM & 53 & B & 2008 & historical \\
\hline Ryan Island & RIM & 61 & C & 2009 & historical \\
\hline Jackson Island & JIC & 71 & C & 2009 & created \\
\hline Whites Island, Cut-off Slough & WHC & 72 & C & $2009 / 10$ & created \\
\hline Wallace Island West & WAC & 77 & C & 2010 & created \\
\hline Clatskanie River (near Anunde Island) & CRM & 80 & C & 2009 & historical \\
\hline Gull Island & GUC & 89 & C & 2009 & created \\
\hline Lord-Walker Island & LI1 & 99 & C & 2009 & created \\
\hline Lord Island & LI2 & 100 & C & 2009 & created \\
\hline Dibblee Slough & DSC & 104 & C & 2005 & created \\
\hline Cottonwood Island, large slough & $\mathrm{Cl} 1$ & 113 & $\mathrm{D}$ & $2005 / 10$ & created \\
\hline Cottonwood Island, small slough & $\mathrm{Cl} 2$ & 114 & D & $2005 / 10$ & created \\
\hline Sandy Island, north slough & SI1 & 121 & $\mathrm{E}$ & 2007 & created \\
\hline Sandy Island, south slough & $\mathrm{S} 12$ & 123 & $\mathrm{E}$ & 2007 & created \\
\hline Martin Island & MIM & 129 & $\mathrm{E}$ & 2007 & historical \\
\hline Goat Island Slough & GIC & 131 & $\mathrm{E}$ & 2009 & created \\
\hline $\begin{array}{l}\text { No-name Island ( } 7.5 \mathrm{rkm} \text { downstream } \\
\text { of the Lewis River mouth) }\end{array}$ & DMI & 136 & $\mathrm{E}$ & 2007 & created \\
\hline Scappoose Bay, mouth of McNulty Cr. & SBM & 143 & $\mathrm{~F}$ & 2010 & historical \\
\hline Cunningham Lake & CLM & 145 & $\mathrm{~F}$ & $2005-10$ & historical \\
\hline Campbell Slough & CS1 & 149 & $\mathrm{~F}$ & 2005-10 & historical \\
\hline $\begin{array}{l}\text { Sauvie Island, east slough (inside } \\
\text { Willow Bar) }\end{array}$ & SSC & 154 & $\mathrm{~F}$ & 2005 & created \\
\hline Water Resources Center & WRC & 175 & G & 2006 & historical \\
\hline McGuire Is. & MIC & 190 & G & 2006 & created \\
\hline Washougal River mouth & WRM & 195 & G & 2010 & historical \\
\hline Sandy River, historical channel & OSR & 196 & G & 2006 & historical \\
\hline Sandy River, historical mouth & OSM & 198 & G & 2007 & historical \\
\hline Gary Island & GAM & 200 & G & & historical \\
\hline Chattham Island & $\mathrm{ClC}$ & 201 & G & 2006 & created \\
\hline Reed Island & RIC & 201 & G & & created \\
\hline $\begin{array}{l}\text { Sand Island (near Rooster Rock State } \\
\text { Park) }\end{array}$ & SIM & 211 & $\mathrm{H}$ & 2008 & historical \\
\hline Franz Lake (near mouth) & FLM & 221 & $\mathrm{H}$ & 2008 & historical \\
\hline Pierce Island & PIM & 228 & $\mathrm{H}$ & 2008 & historical \\
\hline Hardy Creek & $\mathrm{HCM}$ & 230 & $\mathrm{H}$ & 2008 & historical \\
\hline
\end{tabular}

CHM and SRM had two vegetation sample plots at each site to capture high and low marsh vegetation communities; they are referred to as CHM-L, CHM-H, SRM-L, and SRM-H. 



\subsection{Results and Discussion}

\subsection{Annual Monitoring}

\subsubsection{Sediment Composition}

Total organic carbon (TOC) content shows little variation between strata at any of the sites sampled. TOC values at Baker Bay were higher than the other sites, with the Typha angustifolia (TYAN) stratum showing the highest TOC value of all data presented here. Burke Island has the next highest set of values for the site followed by Goat and Deer Islands. Differences in TOC can be caused by numerous controlling factors including the extent of tidal hydrology (greater tidal inundation resulting in greater TOC), marsh age (the older the marsh the greater the TOC), sediment composition, and the species of vegetation present (Thom et al., 2001). Goat, Deer, and Burke Islands are located in the tidal, fluvial portion of the LCRE with less tidal inundation than at Baker Bay. In addition, Goat and Deer Islands are relatively young ( $\sim 50-80 \mathrm{yrs})$, created marshes, while Burke Island was present on historical maps from 130 yrs ago. The age of the Baker Bay marsh is uncertain, as it was not present on the historical maps and likely developed due to changes in hydrology and sediment deposition in Baker Bay caused by the construction of the CR north jetty and creation of islands on the perimeter of the Bay. Vegetation species differed between some of the sites (Table 3), which could potentially affect the TOC content. The highest TOC was from areas with Typha angustifolia (TYAN) and Carex lyngbyei (CALY) and the lowest from areas with Phalaris arundinacea (PHAR) and Eleocharis palustris (ELPA). In general, sediments with greater than 12 percent TOC are considered organic sediments (Mitsch and Gosslink 2000), whereas all results presented here have less than 12 percent TOC. The differences in TOC between multiple sites are discussed further in Section 3.2.1 below.

Table 3. Vegetation strata associated with sediment samples at the 2011 monitoring sites.

\begin{tabular}{lll}
\hline Site & Sample & Vegetation Strata \\
\hline \multirow{3}{*}{ Baker Bay } & CALY & Carex lyngbyei \\
& Channel & Bare mud within channel \\
& DECE & Deschampsia cespitosa \\
& TYAN & Typha angustifolia \\
\multirow{3}{*}{ Burke Island } & PHAR & Phalaris arundinacea \\
& SALA & Sagittaria latifolia \\
& SALA/PHAR & Sagittaria latifolia/Phalaris arundinacea \\
\multirow{3}{*}{ Deer Island } & Sparse ELPA & Sparse Eleocharis palustris \\
& Dense PHAR & Dense Phalaris arundinacea \\
& Sparse PHAR & Sparse Phalaris arundinacea \\
\hline \multirow{3}{*}{ Goat Island } & Sparse ELPA & Sparse Eleocharis palustris \\
& Dense PHAR & Dense Phalaris arundinacea \\
& Sparse PHAR & Sparse Phalaris arundinacea \\
\hline
\end{tabular}

Sediment data for grain size show a similar trend in variation as the TOC data. There is little variation between strata at each site. Baker Bay has the highest variation of grain sizes with a higher clay and coarse sediment content than the other sites. Burke Island has the highest percent of silt throughout the strata. Deer Island has the highest percent of very fine sand. Sediment composition at Deer and Goat 
Islands is very similar. As with the TOC data, this could be related to their age, but also their proximity to each other.

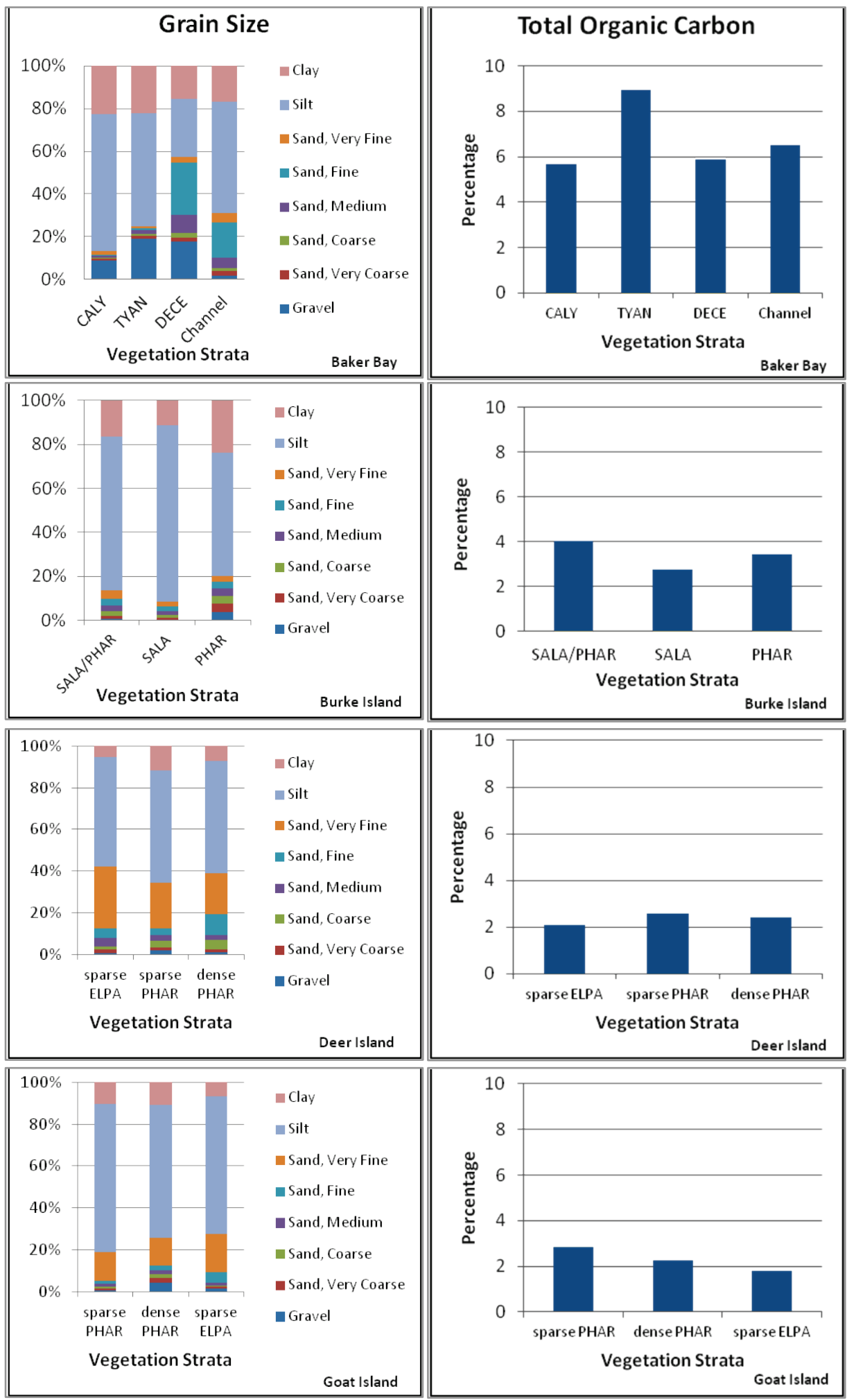

Figure 6. Grain size (on the left) and total organic carbon (TOC; on the right) at Baker Bay and the Reach E sites. 


\subsubsection{Sediment Accretion Rates}

Sediment accretion rates were generally greater than $1.0 \mathrm{~cm} /$ year at the sites measured in 2011 . A higher than average rate would be expected in this year due to the high inundation levels during the spring freshet. The highest levels of sediment accretion are often associated with flood events (Hensel et al., 1999). Observations at the sites in Reaches $\mathrm{E}, \mathrm{F}$, and $\mathrm{H}$, where mud was noted covering up to $20 \%$ of the vegetation, also corroborate these findings. In the lower, tidally dominated part of the estuary, river flooding is not likely a cause of increased accretion rates, and in fact, Whites Island had a very low accretion rate. This could be explained by the higher elevation of the site or the position of the site in the landscape (i.e., an island in the lower part of the floodplain). Conversely, the Baker Bay site appears to be a depositional area based on an assessment of historical maps and imagery, potentially explaining the higher accretion rate at this site. Stakes were installed in the Reach E sites (BIM, DIC, and GIC) in 2011 and will be measured again in 2012 to calculate the annual rates.

Table 4. Sediment accretion rates measured at sites in 2011.

\begin{tabular}{clcccc}
\hline Reach & Site & Rkm & $\begin{array}{c}\text { Sediment Stake } \\
\text { Elevation } \\
\text { (m, CRD) }\end{array}$ & Year & $\begin{array}{c}\text { Accretion/Erosion } \\
\text { Rate (cm/year) }\end{array}$ \\
\hline A & Baker Bay & 6 & 1.81 & $10-11$ & 1.7 \\
\hline C & Whites Island & 72 & 2.05 & $10-11$ & 0.1 \\
\hline F & Cunningham Lake & 145 & 1.49 & $10-11$ & 1.6 \\
& Campbell Slough & 149 & 1.54 & $10-11$ & 1.7 \\
\hline H & Franz Lake & 221 & 1.87 & $10-11$ & 3.0 \\
\hline
\end{tabular}

\section{Hydrology}

Hydrographs from the sites where WSE was collected during the 2010 to 2011 water year indicate that high WSE resulting from the spring freshet was detectable in shallow water wetland habitats at least as far downriver as Whites Island (rkm72); however, this pattern was not observed at the outermost estuary site, Baker Bay (rkm 6) (Figure 7). Also of interest, is that the amount of time the marshes were exposed at each site during the growing season varied considerably. By comparing the average marsh elevation at each site (as denoted by the red line on the hydrographs) to the WSE we can see the variability. For example, the Baker Bay site is exposed consistently every day due to the tidal regime and is likely exposed for more of the day than it is inundated. Similarly, Whites Island follows a consistent tidally driven pattern of inundation and exposure except that there are periodic events where the WSE does not reach a level low enough to expose the marsh. This inundation event occurred for over a month in May and June of 2011 during the spring freshet. Farther upriver at the Campbell Slough and Cunningham Lake sites the pattern is very different, with the marsh exposed during the end of growing season, typically from July through October, and inundated for the early growing season to varying degrees. In 2011, these upriver sites were inundated with greater than a meter of water for most of April and from mid-May through mid-June (see analysis in Section 3.1.5). 

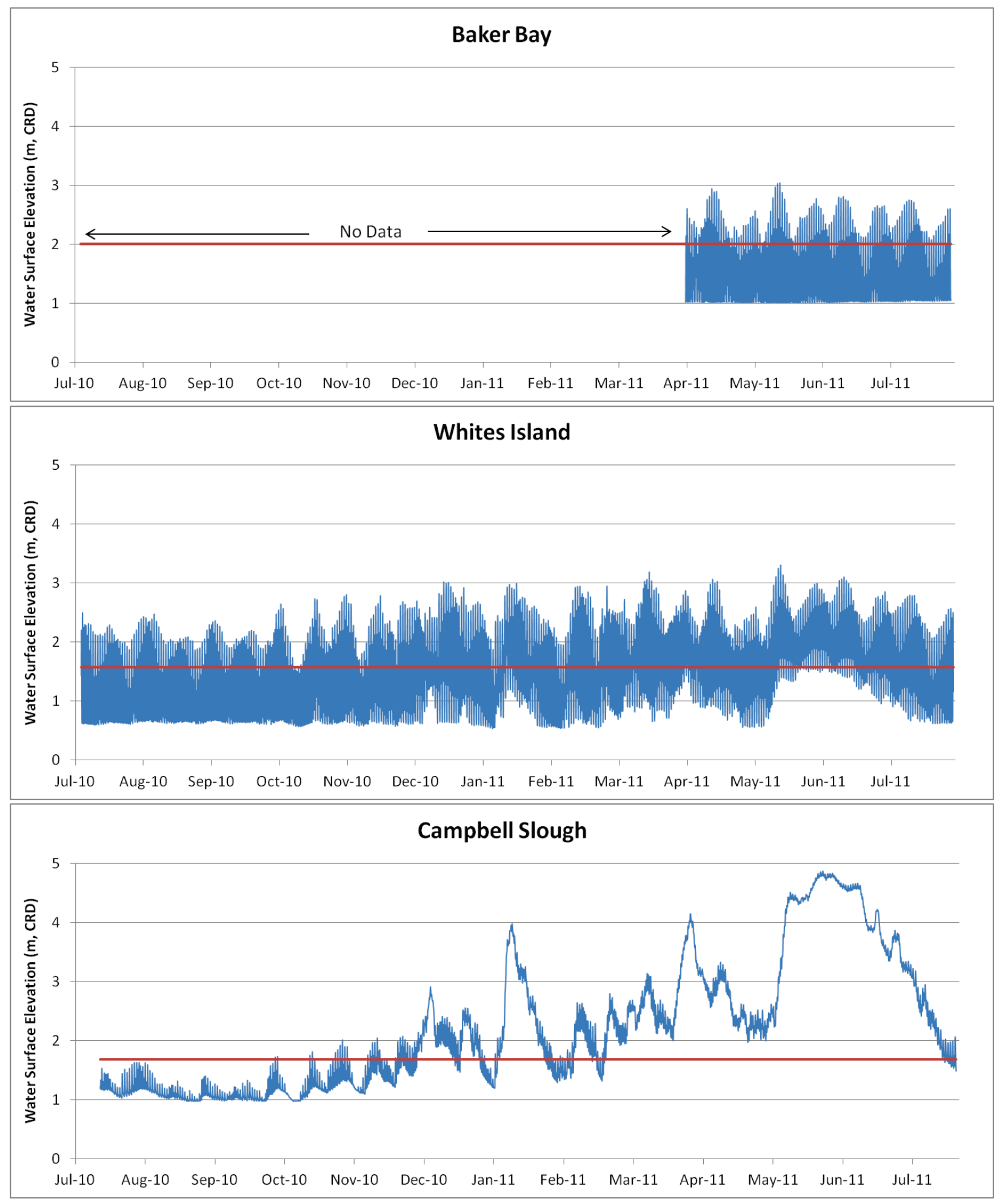

Figure 7. Water surface elevation data from the study sites where sensors were deployed 2010-2011. The red line represents the average elevation of the marsh sampling area. 


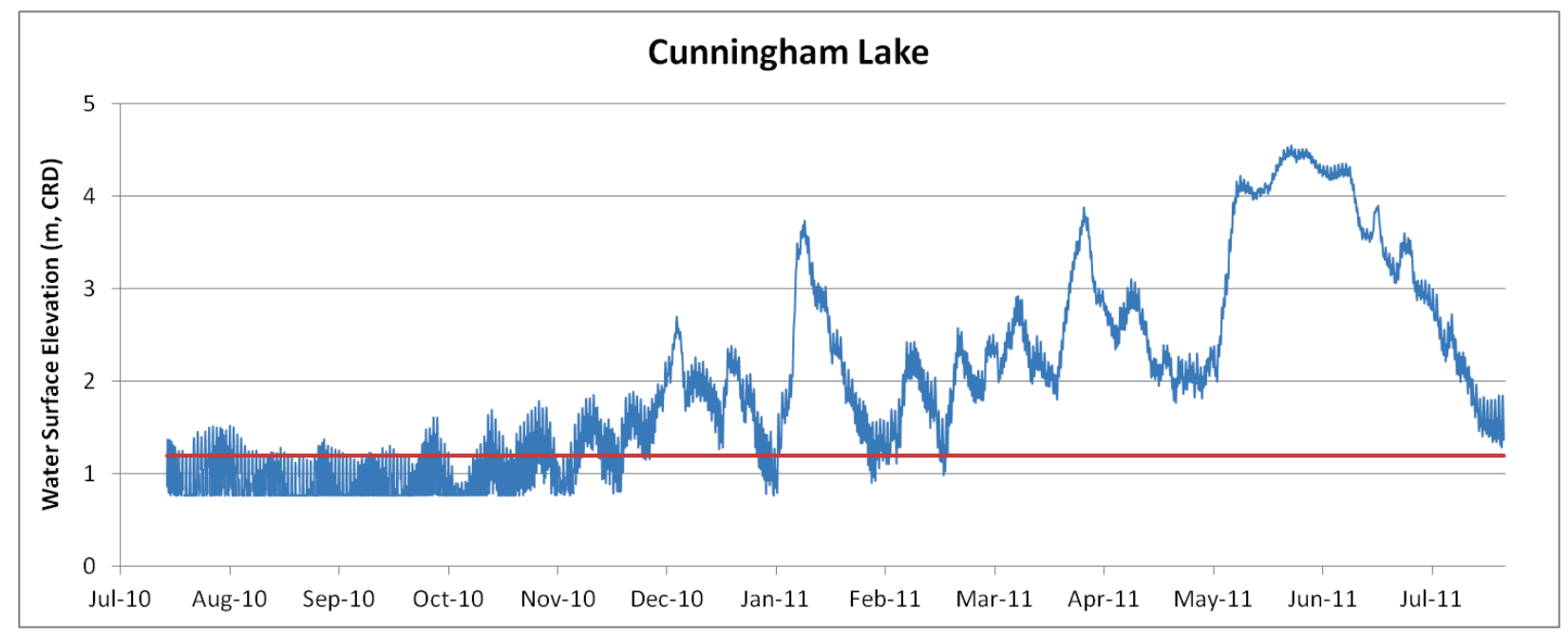

Figure 7. Continued.

\subsubsection{Vegetation Assemblage Structure}

Vegetation cover and biomass was affected in 2011 by the higher than average water year. The prolonged high water coupled with mild fall temperatures resulted in a very late growing season, particularly in the upper portions of the estuary. All sites in Reaches E and F had stunted and sparse vegetation. We were unable to conduct our monitoring during the period established in prior years at the Reach H site (Franz Lake) because the vegetation was underwater. When we were able to monitor the site one month later the vegetation was recovering, however, peak biomass had not yet been reached. A site visit was made in late October at which time much denser vegetation was observed at the site.

In general, species diversity was higher at the Reach $\mathrm{C}$ site than sites sampled in the remaining reaches. Elevation and percent cover of species observed during 2011 sampling are shown in Figure 8. The Baker Bay site had very high cover of native vegetation, with only one non-native species comprising one percent of the cover (Table 5). The marsh was dominated by Carex lyngbyei (CALY) and was the only site where Phalaris arundinacea (PHAR) was not observed. In contrast, Whites Island had $<25 \%$ native cover and was dominated by PHAR ( $>55 \%$ cover). Whites Island had the highest species richness of any of the sites at 38 species. The upland border at all upriver sites, which was not part of the sample area, was comprised of willows (Salix spp.), cottonwood (Populus balsamifera), and ash (Fraxinus latifolia). At Baker Bay, the upland area was dominated by conifers. Maps of vegetation distributions at each site illustrate vegetation patterns and the spatial distribution of each major species communities relative to tidal channels at each site (Appendix B).

The upriver sites all shared some common vegetation traits in this high-water year. The upriver sites had higher cover in the categories of open water $(>40 \%)$ and bare ground $(>20 \%)$ and generally lower vegetative cover than previous years (Borde et al., 2011b). PHAR cover is in the top 5 species at all of the upriver sites. Eleocharis palustris (ELPA), Sagittaria latifolia (SALA), and Salix lucida (SALU) are the primary native species at all of the upriver sites. Campbell Slough and Cunningham Lake showed decreased species diversity cover from previous years, again probably due the high water. 
Table 5. Species richness and areal cover of native and non-native species at the 2011 monitoring sites.

\begin{tabular}{lcccc}
\hline Site & \# Native species & $\begin{array}{c}\text { Native species } \\
\text { percent cover }\end{array}$ & $\begin{array}{c}\text { \# Non-native } \\
\text { species }\end{array}$ & $\begin{array}{c}\text { Non-native species } \\
\text { percent cover }\end{array}$ \\
\hline Baker Bay & 17 & 107.6 & 1 & 1.1 \\
\hline Whites Island & 25 & 24.6 & 13 & 68.6 \\
\hline Burke Island & 13 & 25.8 & 7 & 8.5 \\
\hline Goat Island & 9 & 16.1 & 3 & 15.5 \\
\hline Deer Island & 14 & 15.9 & 6 & 19.3 \\
\hline Campbell Slough & 12 & 21.6 & 3 & 34.9 \\
\hline Cunningham Lake & 9 & 13.0 & 4 & 40.6 \\
\hline Franz Lake & 16 & 33.8 & 3 & 32.2 \\
\hline
\end{tabular}
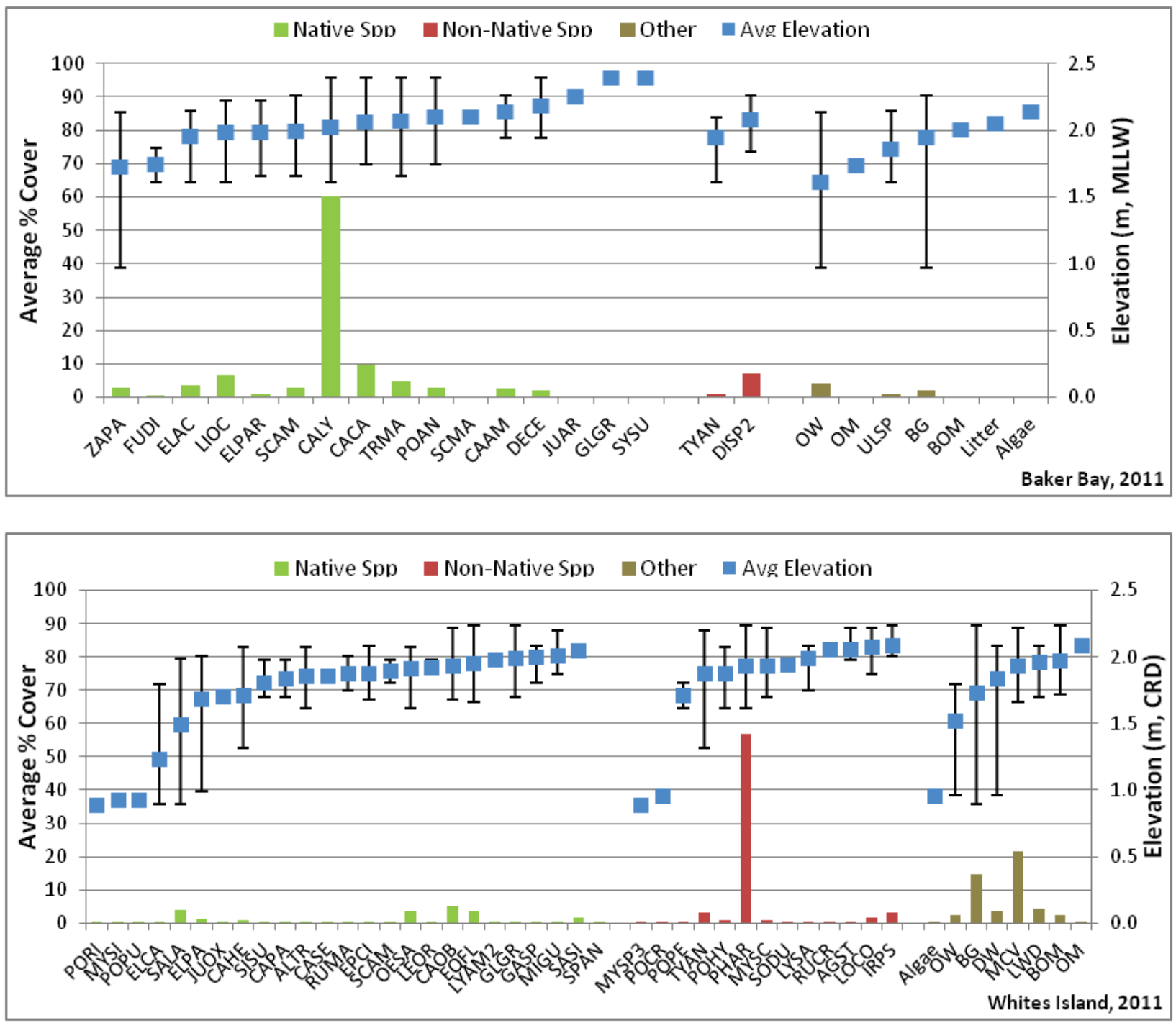

Figure 8. Vegetation species cover and elevations for sites sampled in 2011. Bars represent the minimum and maximum elevations at which the vegetative species occurred within the sample area (See Appendix $\mathrm{C}$ for species names associated with codes along the $\mathrm{x}$-axis). 


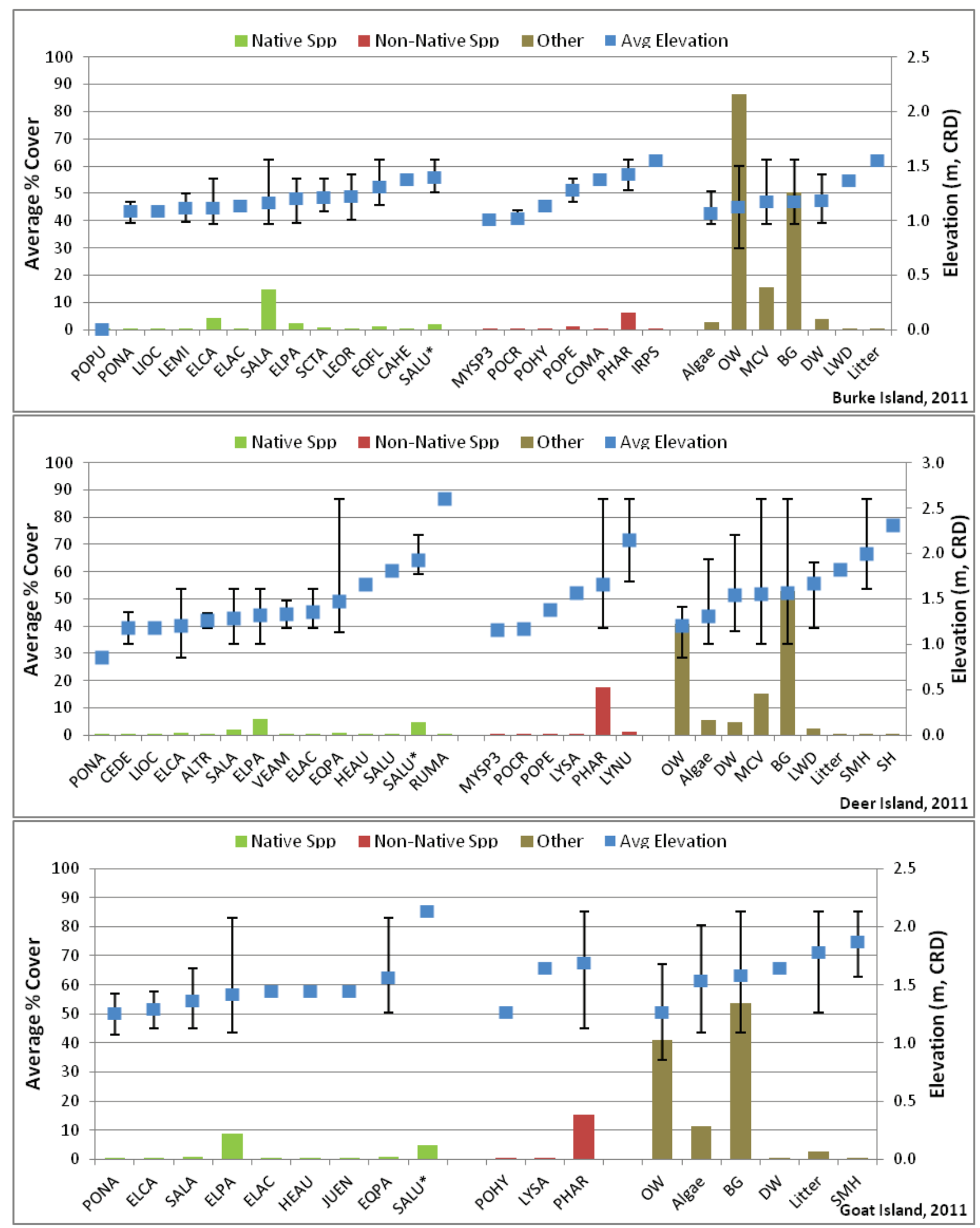

Figure 8. Continued (note slightly higher elevation scale for Deer Island plot). 


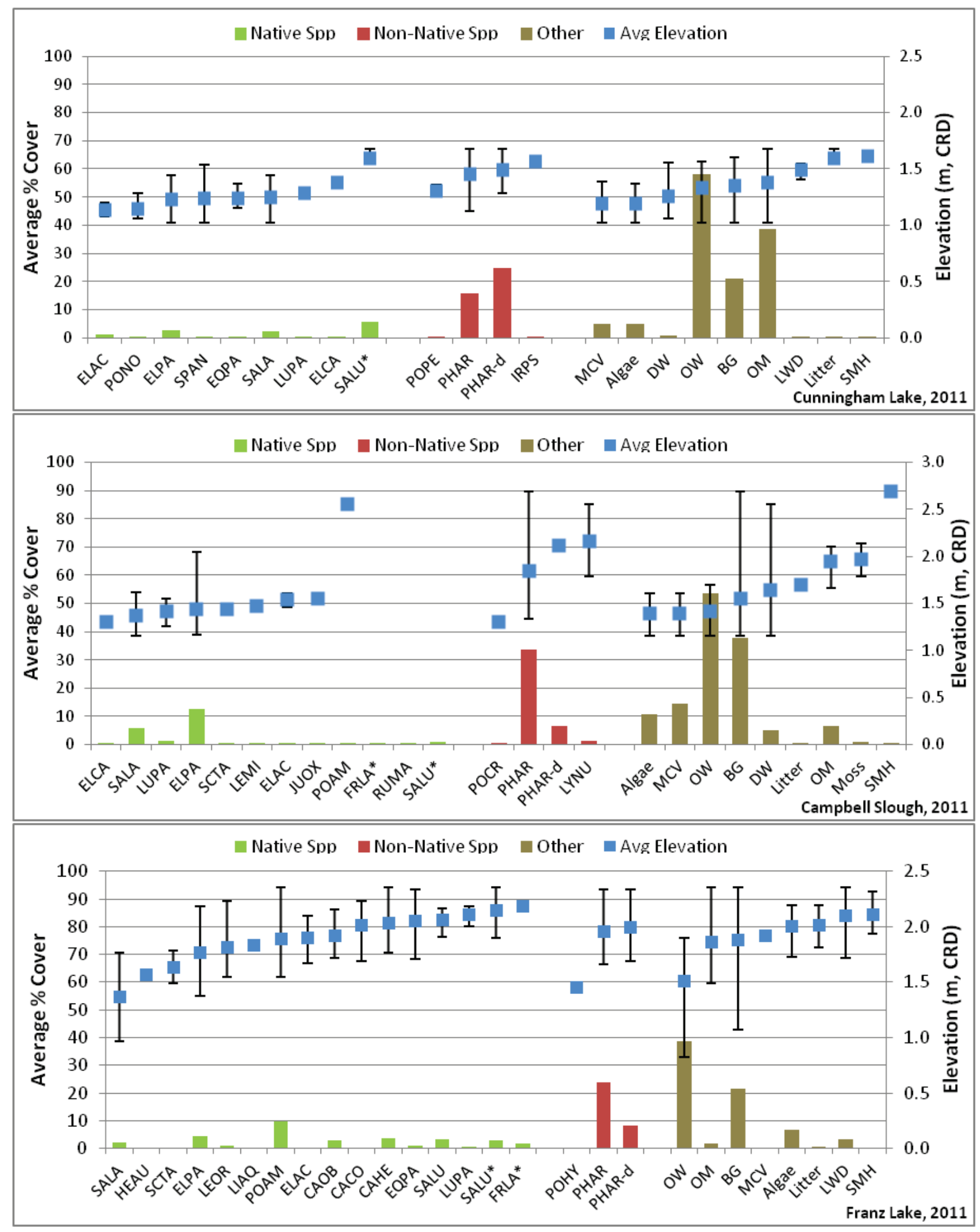

Figure 8. Continued (note slightly higher elevation scale for Campbell Slough plot). 


\subsubsection{Biomass}

The biomass sample design is such that samples are collected in the summer at peak biomass and then again in winter, just prior to the initiation of primary production in the next growing season. In this way, the annual primary production can be estimated as well as the potential amount of biomass exported from the wetland. The four core sites were sampled for summer biomass in 2011 (Table 6) and the winter biomass will be collected at the same sites in early 2012. Due to high water in the two upriver sites the timing of peak biomass was delayed. Sampling of the biomass was delayed until late August, however, the mild fall weather likely delayed the peak season until late fall. Therefore, the results shown in Table 6 portray the effect of the high water on biomass production, however they are perhaps not indicative of potential or realized biomass production at all the sites. The two lower estuary sites (BBM and WHC) have the highest emergent and submerged aquatic vegetation (SAV) biomass. These results are likely representative of peak biomass at the BBM site and possibly at $\mathrm{WHC}$, however, the total vegetation cover was slightly lower at the time of sampling in 2011 than it had been in the previous two years: 107, 101, and 93 percent in 2009, 2010, and 2011 respectively (numbers greater than 100 occur when multiple layers of vegetation are present).

Table 6. Average dry weight per site of emergent and submerged aquatic vegetation biomass for the summer 2011 sampling period.

\begin{tabular}{lcc}
\hline Site & Vegetation Strata & $\begin{array}{c}\text { Average } \\
\text { (Dry Wt., g/m }\end{array}$ \\
\hline Baker Bay (BBM) & Emergent & 864.5 \\
Whites Island & Submerged & 81.8 \\
(WHC) & Emergent & 802.6 \\
Campbell Slough & Submerged & 51.8 \\
(CS1) & Emergent & 256.8 \\
\hline Franz Lake (FLM) & Submerged & 1.8 \\
\hline
\end{tabular}

*No SAV was observed or collected at the site due to high water.

\subsubsection{Elevation, Inundation, and Vegetation Interactions}

Average elevations of each vegetation sampling area and their location in the River are provided in Table 7 and Figure 9. The elevations of the sites monitored in 2011 cover a narrow range between $0.85 \mathrm{~m}$ and $2.69 \mathrm{~m}$ with the average site elevations between 1.0 and $2.0 \mathrm{~m}$. Although the elevations are similar, the inundation patterns are very different. The percent of time the average marsh elevations were inundated varied from 20 percent at BBM to 65 percent at CLM during the deployment periods and between 14 and 54 percent at WHC and CLM, respectively, during the growing season (see Figure 7 for hydrographs from the sites). Similarly, the sum exceedance value (SEV), representing the amount of water over a site in a given time period, was much higher at the upper estuary sites (Figure 11 and Table 8 ) than at WHC. The difference between years is also very noticeable at the two upper estuary sites, whereas the SEV at WHC was only slightly elevated in 2011 (278 versus 230 in 2010). 
Table 7. Average elevation of vegetation survey areas (relative to CRD).

\begin{tabular}{|c|c|c|c|c|}
\hline Reach & Site & Site Code & $\mathbf{R k m}$ & $\begin{array}{l}\text { Average } \\
\text { Elevation } \\
\text { (m, CRD) }\end{array}$ \\
\hline A & Baker Bay & BBM & 6 & 2.00 \\
\hline C & Whites Island & WHC & 72 & 1.95 \\
\hline \multirow{3}{*}{ E } & Burke Island & BIM & 131 & 1.18 \\
\hline & Goat Island & GIC & 131 & 1.57 \\
\hline & Deer Island & DIC & 132 & 1.51 \\
\hline \multirow{2}{*}{$\mathbf{F}$} & Cunningham Lake & CLM & 145 & 1.37 \\
\hline & Campbell Slough & $\mathrm{CS} 1$ & 149 & 1.66 \\
\hline $\mathbf{H}$ & Franz Lake & FLM & 221 & 1.85 \\
\hline
\end{tabular}

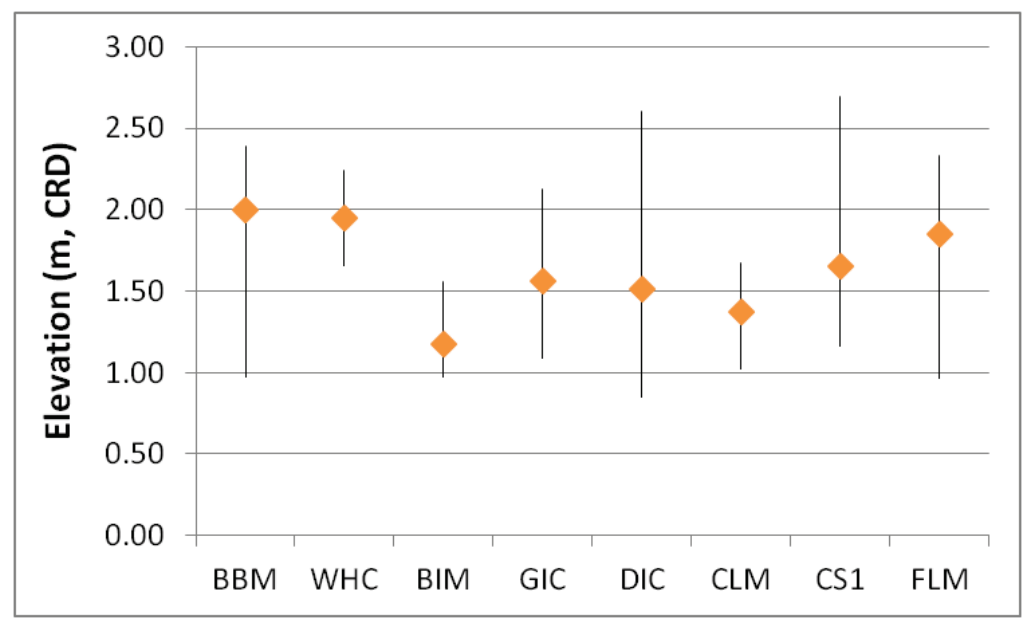

Figure 9. Average elevation of the vegetation survey area (points) with the range of elevations measured in the vegetated survey area (lines).

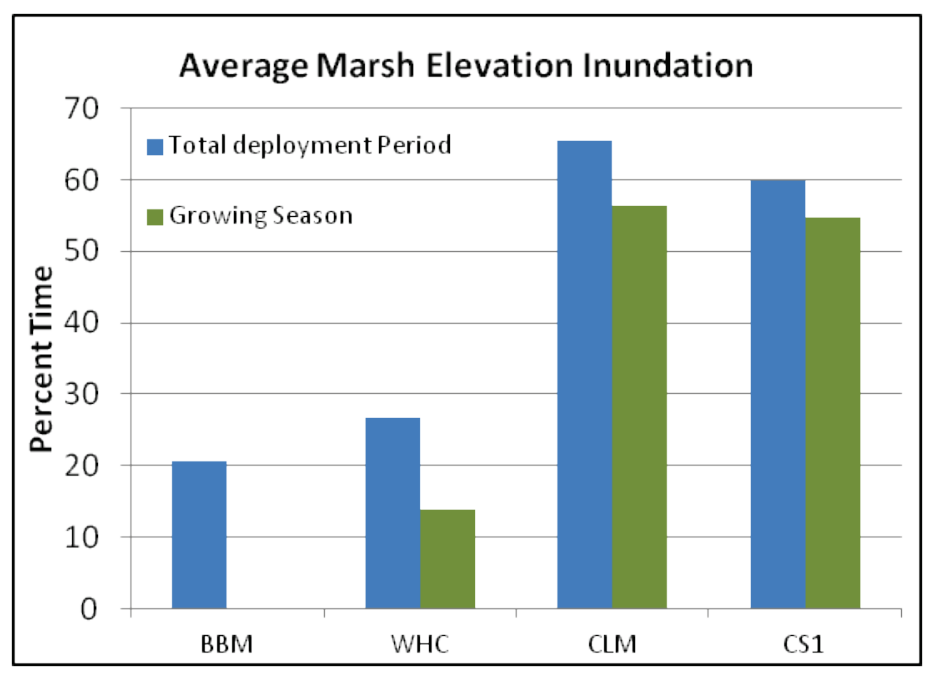

Figure 10. Percent of time the average marsh elevation was inundated at each site during the deployment period and during the growing season. 


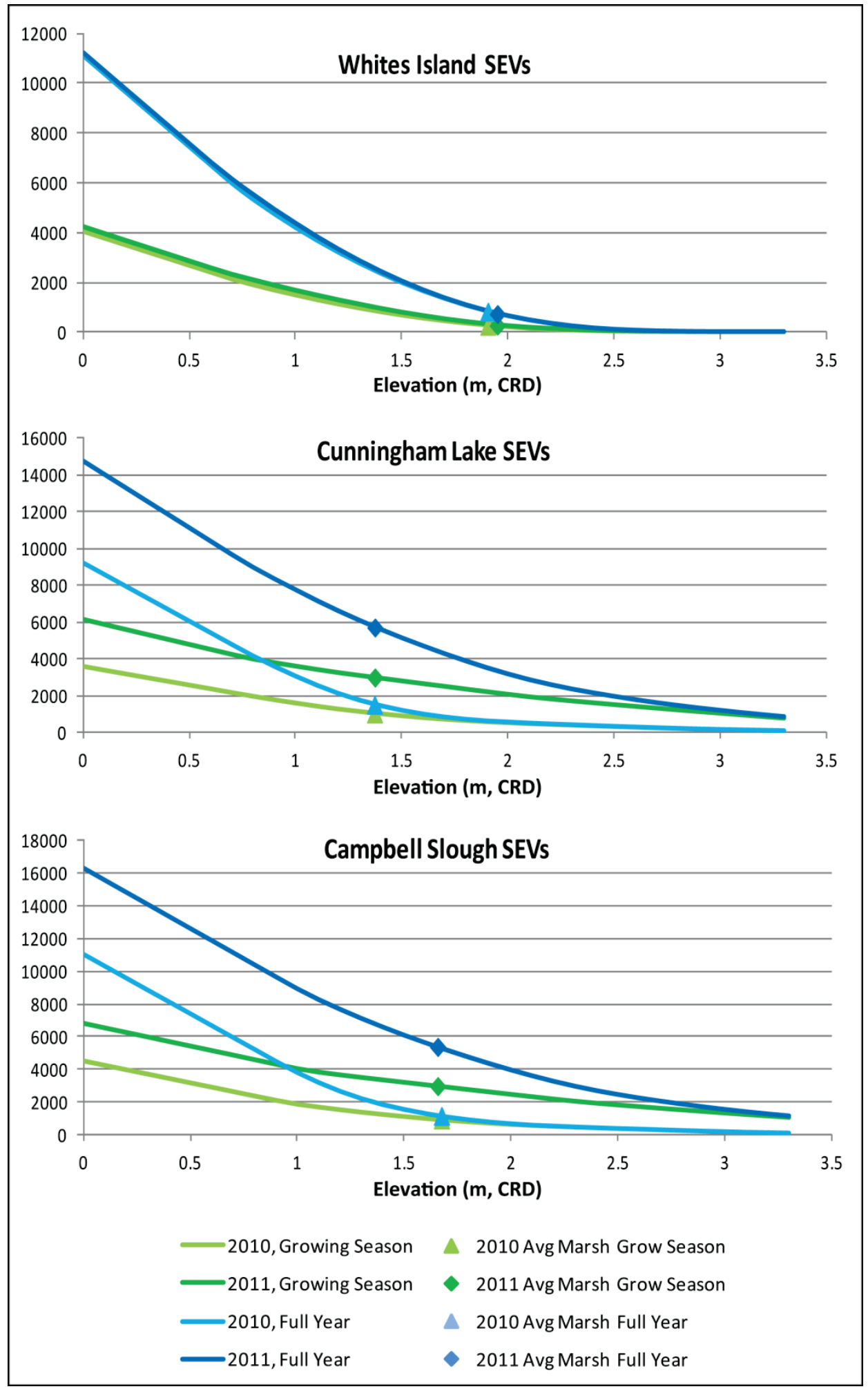

Figure 11. Sum Exceedance Values for the 2009-2010 period compared with the 2010-2011 period. 
The lower vegetation cover in the upper estuary sites noted in Section 3.1.3 is undoubtedly a result of the higher inundation at these sites during the growing season. The difference in inundation as measured by the SEV is an order of magnitude greater at the upper estuary sites as shown in Table 8 . The duration of the effect of higher growing season inundation is uncertain. Observations at sites later in the 2011 growing season indicate that the vegetation may have eventually reached biomass production levels equivalent to lower-water years, however we currently have no data to determine the timing or extent to which this happens.

Table 8. Sum exceedance values for the sites where water level data were collected from 2010-2011.

\begin{tabular}{lcc}
\hline Site & $\begin{array}{c}\text { Average Marsh } \\
\text { Elevation (m, CRD) }\end{array}$ & $\begin{array}{c}\text { Growing Season } \\
\text { SEV (m-hours) }\end{array}$ \\
\hline Whites Island & 1.95 & 278.3 \\
\hline Cunningham Lake & 1.37 & 2997.6 \\
\hline Campbell Slough & 1.66 & 2994.8 \\
\hline
\end{tabular}

\subsubsection{Channel Morphology and Inundation}

Channel cross-section morphologies are shown in Figure 12 and channel morphometrics and inundation times are provided in Table 9. For the purposes of the Ecosystem Monitoring program, the channel mouth is generally defined as the location where vegetation begins along the channel bank, and this location is usually designated as channel cross section 1 (XS1). Exceptions based on site configuration necessarily occur. For example, Whites Island and Goat Island do not have a cross-section at channel mouth noted because the channel at the site is a secondary channel to a main channel where vegetation is growing along then entire bank. The site at Cunningham Lake is approximately $6.5 \mathrm{~km}$ from Multnomah Channel and the mouth has not been surveyed as part of this program. At Deer Island and Franz Lake, the cross-section designated as "XS0" is the XS that would typically be designated as XS1, but because the initial survey did not include a XS at the outer edge of the bank vegetation, XS0 was added later to ensure the mouth was surveyed.

In some cases, the channel mouth cross-section is shallower than the next cross-section upstream (e.g., BBM and DIC). This sill effect controls hydrologic connectivity during low water. Campbell Slough has a rip rap weir across the mouth which restricts access once the WSE of the Columbia River is below $0.89 \mathrm{~m}$ (Table 9; this was surveyed in 2010 and is discussed in Borde et al 2011b). The sill effect is observable in the frequency of inundation; at BBM and CS1, inundation of the $1^{\text {st }}$ channel is noticeably less than the inundation period of the next cross-section up-channel. Channel inundation for Reach $\mathrm{E}$ will be discussed in detail in the following year when the hydrology data has been collected. 

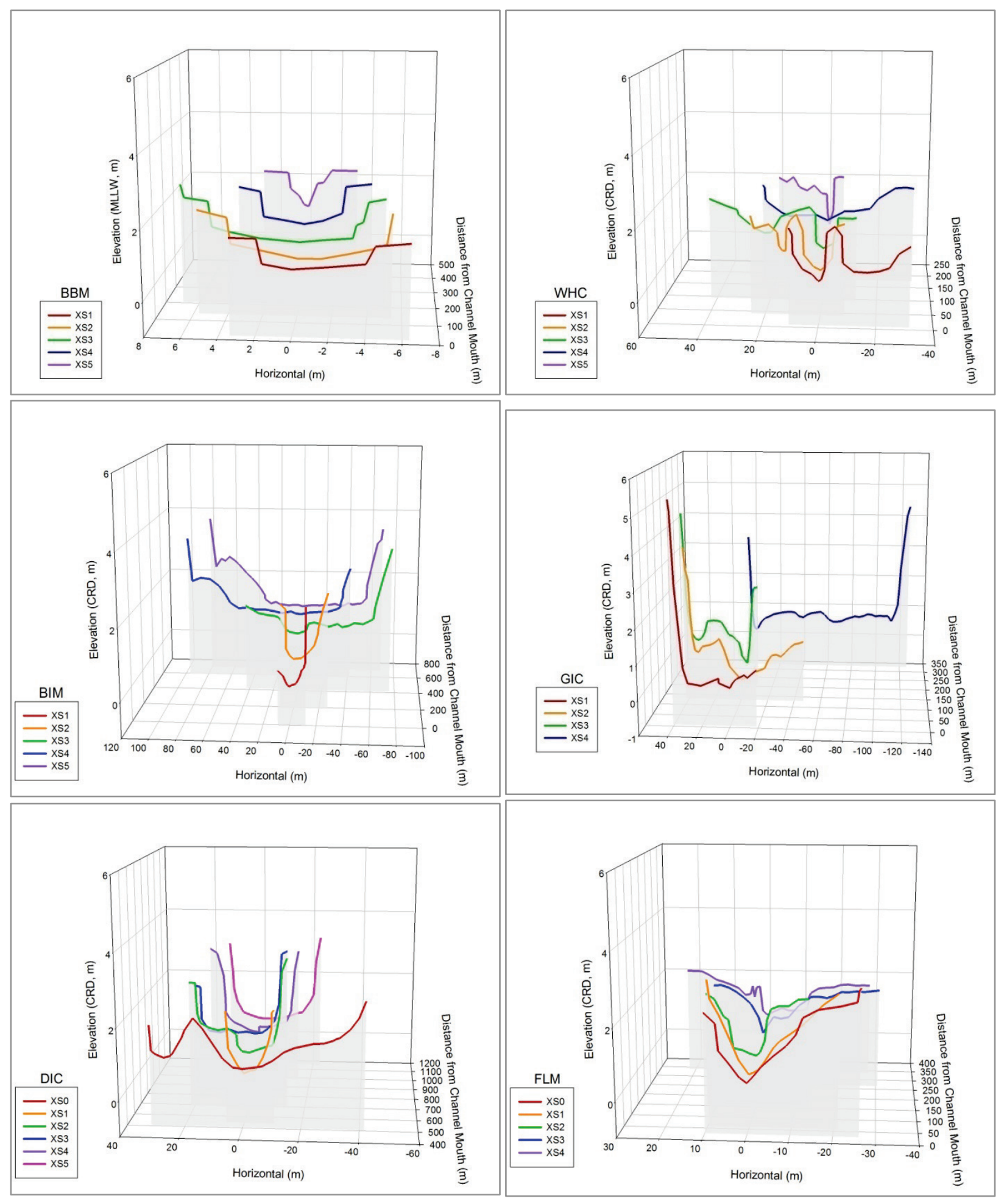

Figure 12. Relative elevations of the channel cross sections for the 2011 sites with multiple cross sections. 
Table 9. Channel metrics and inundation frequencies during the annual deployment period and during the peak juvenile Chinook salmon migration period (March $1^{\text {st }}$ to July $31^{\text {st }}$ ). .*

\begin{tabular}{|c|c|c|c|c|c|c|c|c|}
\hline \multirow[b]{2}{*}{$\begin{array}{l}\text { Site } \\
\text { (sensor } \\
\text { elevation } \\
\text { m, CRD) }\end{array}$} & \multirow[b]{2}{*}{$\begin{array}{c}\text { Cross } \\
\text { Section } \\
\text { Location } \\
\end{array}$} & \multirow[b]{2}{*}{$\begin{array}{c}\text { Bank } \\
\text { Elevation } \\
\text { (m, CRD) }\end{array}$} & \multirow[b]{2}{*}{$\begin{array}{l}\text { Thalweg } \\
\text { Elevation } \\
\text { (m, CRD) }\end{array}$} & \multirow[b]{2}{*}{$\begin{array}{c}\text { Channel } \\
\text { Depth } \\
\text { (m) }\end{array}$} & \multicolumn{2}{|c|}{$\begin{array}{c}\text { Annual Deployment } \\
\text { Period }\end{array}$} & \multicolumn{2}{|c|}{$\begin{array}{c}\text { Peak Salmon Migration } \\
\text { Period }\end{array}$} \\
\hline & & & & & $\begin{array}{c}\text { Frequency } \\
\text { WSE } \\
>\text { thalweg } \\
+50 \mathrm{~cm} \\
\end{array}$ & $\begin{array}{c}\text { Frequency } \\
\text { WSE }>\text { top } \\
\text { channel } \\
\text { bank }+10 \\
\text { cm } \\
\end{array}$ & $\begin{array}{c}\text { Frequency } \\
\text { WSE > } \\
\text { thalweg } \\
+50 \mathrm{~cm}\end{array}$ & $\begin{array}{c}\text { Frequency } \\
\text { WSE }>\text { top } \\
\text { channel } \\
\text { bank }+10 \\
\text { cm }\end{array}$ \\
\hline \multirow{5}{*}{$\begin{array}{l}\text { Baker Bay } \\
(0.83)\end{array}$} & 1 (mouth) & 1.59 & 0.90 & 0.68 & 48 & 35 & 48 & 35 \\
\hline & 2 & 1.86 & 0.70 & 1.16 & 56 & 22 & 57 & 22 \\
\hline & 3 & 2.12 & 0.90 & 1.22 & 48 & 10 & 48 & 10 \\
\hline & 4 & 2.00 & 1.01 & 0.99 & 43 & 16 & 43 & 16 \\
\hline & 5 & 2.26 & 1.17 & 1.09 & 36 & 7 & 36 & 6 \\
\hline \multirow{5}{*}{$\begin{array}{l}\text { Whites } \\
\text { Island } \\
(0.65)\end{array}$} & 1 & 1.10 & 0.28 & 0.82 & 83 & 65 & 94 & 80 \\
\hline & 2 & 1.41 & 0.34 & 1.07 & 81 & 49 & 93 & 64 \\
\hline & 3 & 1.53 & 0.61 & 0.92 & 69 & 43 & 83 & 57 \\
\hline & 4 & 1.93 & 0.92 & 1.00 & 54 & 23 & 69 & 32 \\
\hline & 5 & 1.45 & 0.44 & 1.01 & 76 & 47 & 89 & 61 \\
\hline \multirow{5}{*}{$\begin{array}{l}\text { Burke Island } \\
(0.83)\end{array}$} & 1 (mouth) & 0.53 & 0.09 & 0.44 & & & & \\
\hline & 2 & 1.89 & 0.46 & 1.43 & & & & \\
\hline & 3 & 1.22 & 0.74 & 0.48 & & & & \\
\hline & 4 & 1.78 & 0.98 & 0.80 & & & & \\
\hline & 5 & 1.75 & 1.05 & 0.70 & & & & \\
\hline \multirow{4}{*}{$\begin{array}{l}\text { Goat Island } \\
(0.67)\end{array}$} & 1 & 0.64 & 0.11 & 0.53 & & & & \\
\hline & 2 & 0.84 & -0.37 & 1.21 & & & & \\
\hline & 3 & 2.11 & -0.31 & 2.42 & & & & \\
\hline & 4 & 2.29 & 0.20 & 2.09 & & & & \\
\hline \multirow{6}{*}{$\begin{array}{l}\text { Deer Island } \\
(0.67)\end{array}$} & 0 (mouth) & 1.84 & 0.66 & 1.18 & & & & \\
\hline & 1 & 2.15 & 0.43 & 1.72 & & & & \\
\hline & 2 & 2.64 & 0.63 & 2.01 & & & & \\
\hline & 3 & 2.18 & 0.79 & 1.39 & & & & \\
\hline & 4 & 2.28 & 0.48 & 1.80 & & & & \\
\hline & 5 & 2.43 & 0.51 & 1.92 & & & & \\
\hline Cunningham & & & & & & & & \\
\hline $\begin{array}{l}\text { Lake } \\
(0.75)\end{array}$ & 1 & 1.02 & 0.75 & 0.27 & 70 & 77 & 98 & 99 \\
\hline \multirow{3}{*}{$\begin{array}{l}\text { Campbell } \\
\text { Slough } \\
(0.97)\end{array}$} & 1 (mouth)* & 2.009 & 0.891 & 1.118 & 69 & 47 & 97 & 90 \\
\hline & 2 (mouth)* & 1.854 & -0.308 & 2.162 & 100 & 52 & 100 & 94 \\
\hline & 3 & 1.30 & 0.79 & 0.51 & 73 & 68 & 97 & 97 \\
\hline \multirow{5}{*}{$\begin{array}{l}\text { Franz Lake } \\
(0.81)\end{array}$} & 0 (mouth) & 2.03 & 0.42 & 1.61 & & & & \\
\hline & 1 & 1.24 & 0.48 & 0.75 & & & & \\
\hline & 2 & 1.53 & 0.48 & 1.05 & & & & \\
\hline & 3 & 1.47 & 0.60 & 0.87 & & & & \\
\hline & 4 & 1.42 & 0.82 & 0.59 & & & & \\
\hline
\end{tabular}

* Inundation frequency is only calculated for the sites where on-site water surface elevation (WSE) data was collected for the 2010-2011 monitoring period. 


\subsection{Spatial Pattern Analysis}

The results presented here describe patterns observed in habitat structure along the longitudinal gradient of the LCRE. The data are from the 39 sites listed in Section 2.2, which were sampled under multiple research studies, including the Ecosystem Monitoring program, as described in Section 1.4. Site codes used in the analysis are defined in Table 2.

\subsubsection{Sediment Composition}

Total organic carbon (TOC) content of the sediment samples does not seem to vary longitudinally along the estuarine gradient; however, signatures of vegetation strata and habitat types are evident in some cases (Figure 13). Typically, TOC was higher in the marsh (MA or specific vegetation code) samples than in the channel $(\mathrm{CH})$ samples, with the highest TOC in areas dominated by grass (PHAR, DISP). One exception is the $\mathrm{CH}$ sample from JIC, which may be due to high amounts of submerged aquatic vegetation (SAV) at this site. Also notable is that TOC levels were generally higher at historical sites than created sites.

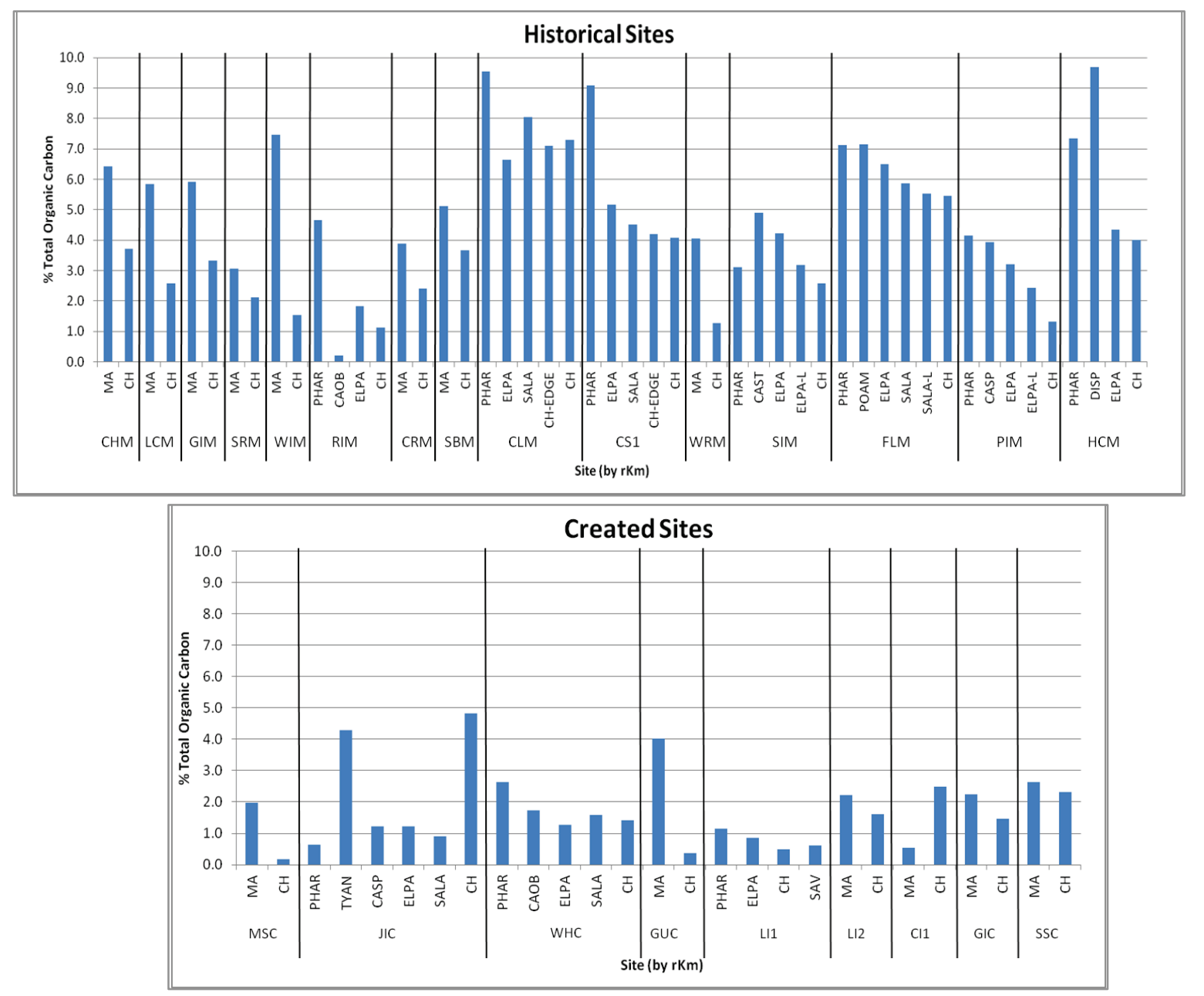

Figure 13. Percent total organic carbon (TOC) by strata at historical (top) and created (bottom) marsh sites. Sites are ordered by distance from the LCR mouth, starting at left. 
The sediment grain size at the marsh sites analyzed in this study is predominantly silt, very fine, and fine sand (Figure 14). This pattern was true for both historical and created marsh sites, with a few exceptions. Three sites had more sand than silt (SIM, PIM, and LI1) and one site (HCM) was dominated by coarse sand and gravel. Historical sites had a greater percentage of clay (10-20\%) than the created sites $(<10 \%)$. Differences between strata within sites were generally not distinctive, except for a few cases where the channel $(\mathrm{CH})$ had more coarse sediment than the marsh (MA) and one case where CAOB (Carex obnupta) had more coarse sediments in an area near the outer boundary of the site.
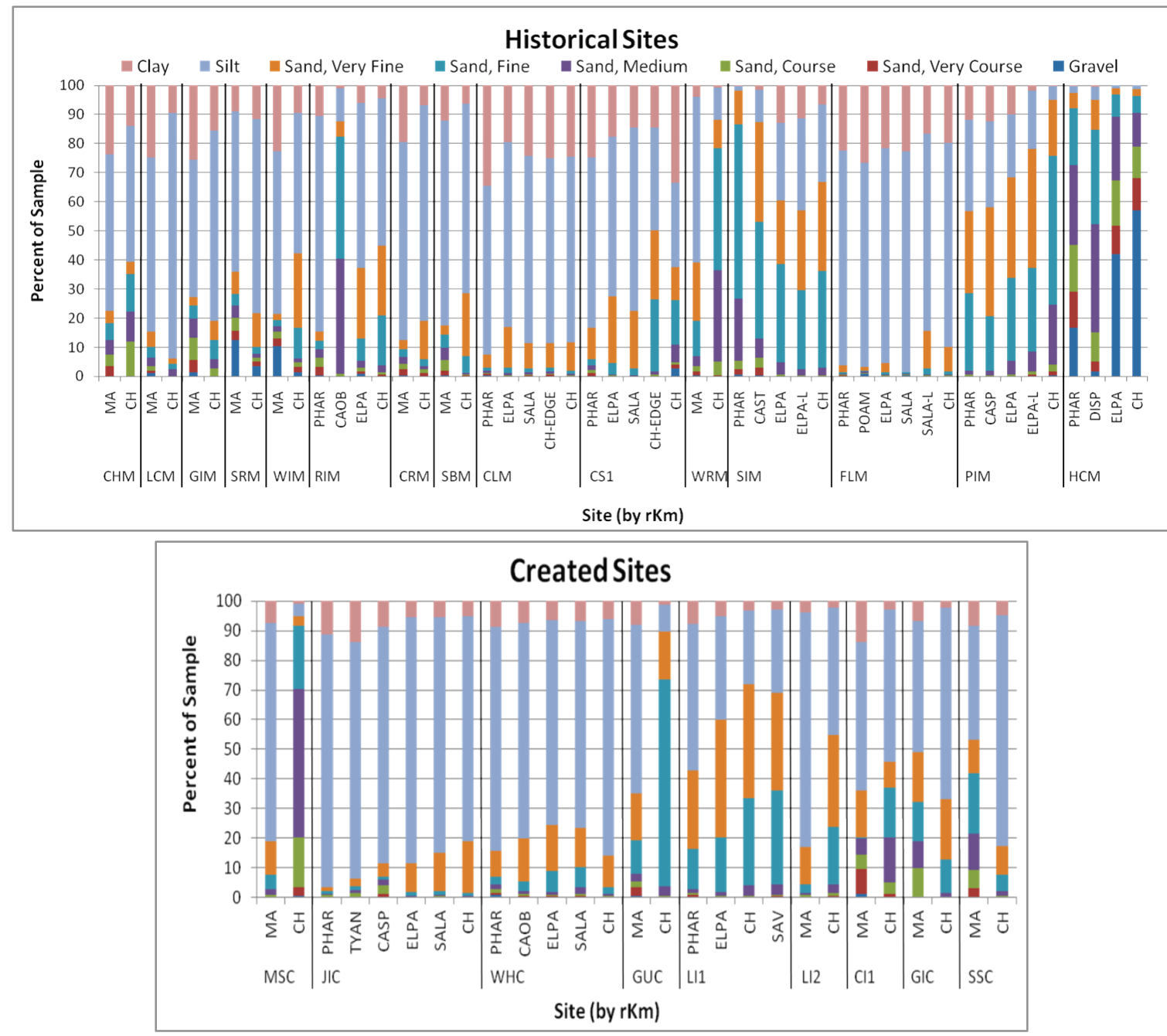

Figure 14. Sediment grain size composition of historical and created marshes, distinguished by strata within the sites. Samples were either taken within the marsh (MA) and channel (CH) strata or separated further into vegetation strata.

\subsubsection{Accretion Rates}

Annual accretion rates for 22 marshes are shown in Figure 15. Generally, sediment either accreted (positive values) or eroded (negative values) at rates between 2.0 and $-2.0 \mathrm{~cm} /$ year (yr). The average accretion rates for the created marshes is $0.78 \mathrm{~cm} / \mathrm{yr}$ and the rate for historical marshes is $-0.44 \mathrm{~cm} / \mathrm{yr}$, including the $-7.8 \mathrm{~cm} / \mathrm{yr}$ extreme measured at Sand Island Marsh, SIM. Without SIM, the rate for 
historical marshes is $0.22 \mathrm{~cm} / \mathrm{yr}$. In either case, the difference between rates at historical and created sites is not statistically significant.

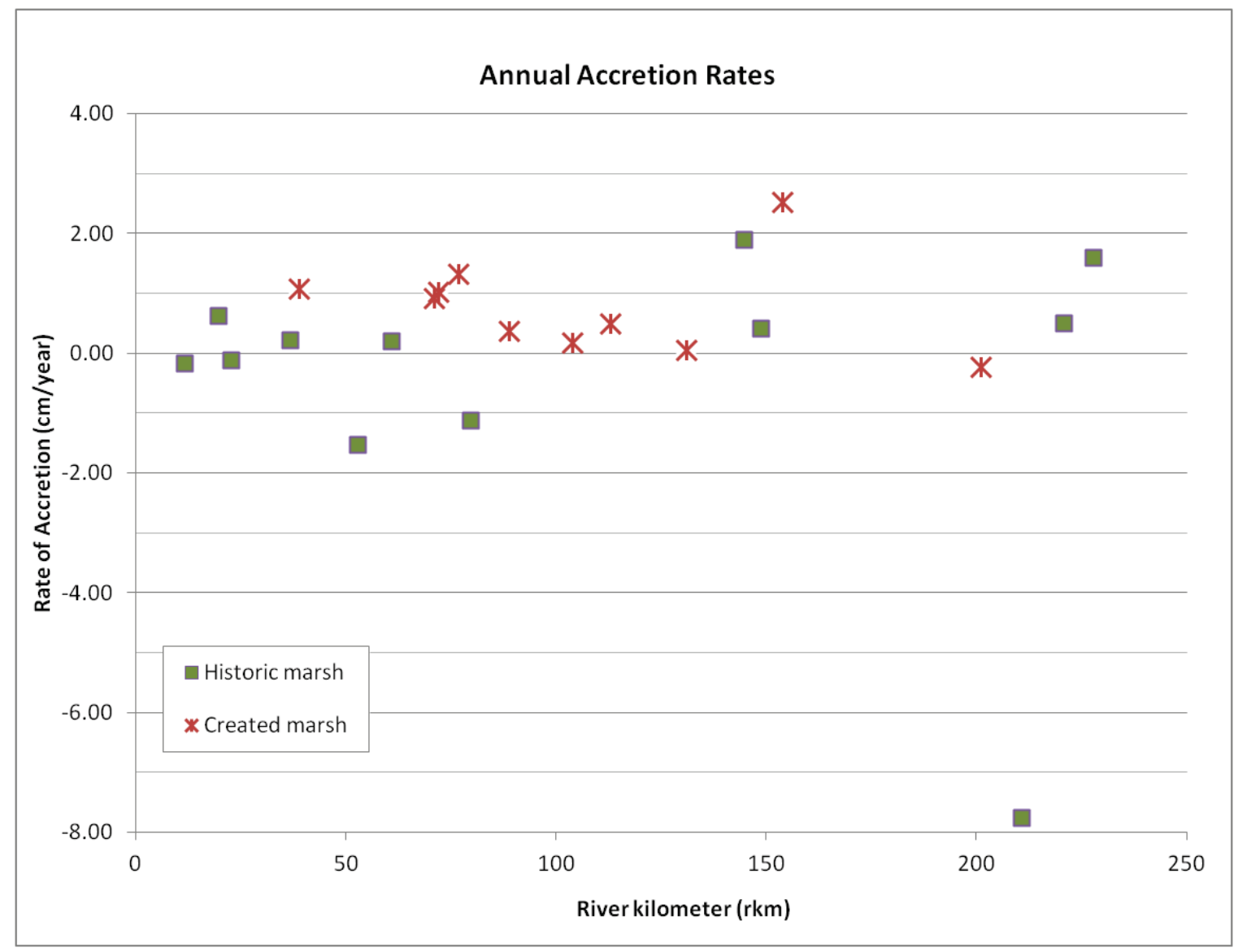

Figure 15. Annual sediment accretion and erosion rates for marshes along the river gradient.

\subsubsection{Hydrology}

Using the hydrology data and elevation data collected at the sites, inundation times and sum exceedance values (SEVs) were calculated for average marsh elevations. These were separated into historic and created sites and graphed along the estuarine gradient (Figure 16; the site names and rkm can be determined from Table 2). Most of the data is from the years 2009 and 2010, years that were neither anomalously high nor low. The most notable trend in this data is the general increase in inundation time and magnitude in the upper portions of the river. Exceptions include a very low elevation site at rkm 37 (SRM-L; the low marsh portion of the Secret River marsh) and higher elevation sites at rkm 99 and 195 (LI1 and WRM, respectively). Also notable is the switch from a higher percent inundation in the total year (TY) below approximately rkm 130 - 145 to a higher percent inundation during the growing season. Also, above rkm 190, the SEV, an indication of the magnitude of inundation, was considerably higher than the percent of time inundated. The SEV for the growing season graphed against elevation shows little relationship when the entire estuary is graphed together (Figure 17), however when the estuary is divided into hydrologic zones the relationship is more apparent (Figure 18). The zones used for this analysis are based on Jay et al (in review) and Borde et al (2012). 

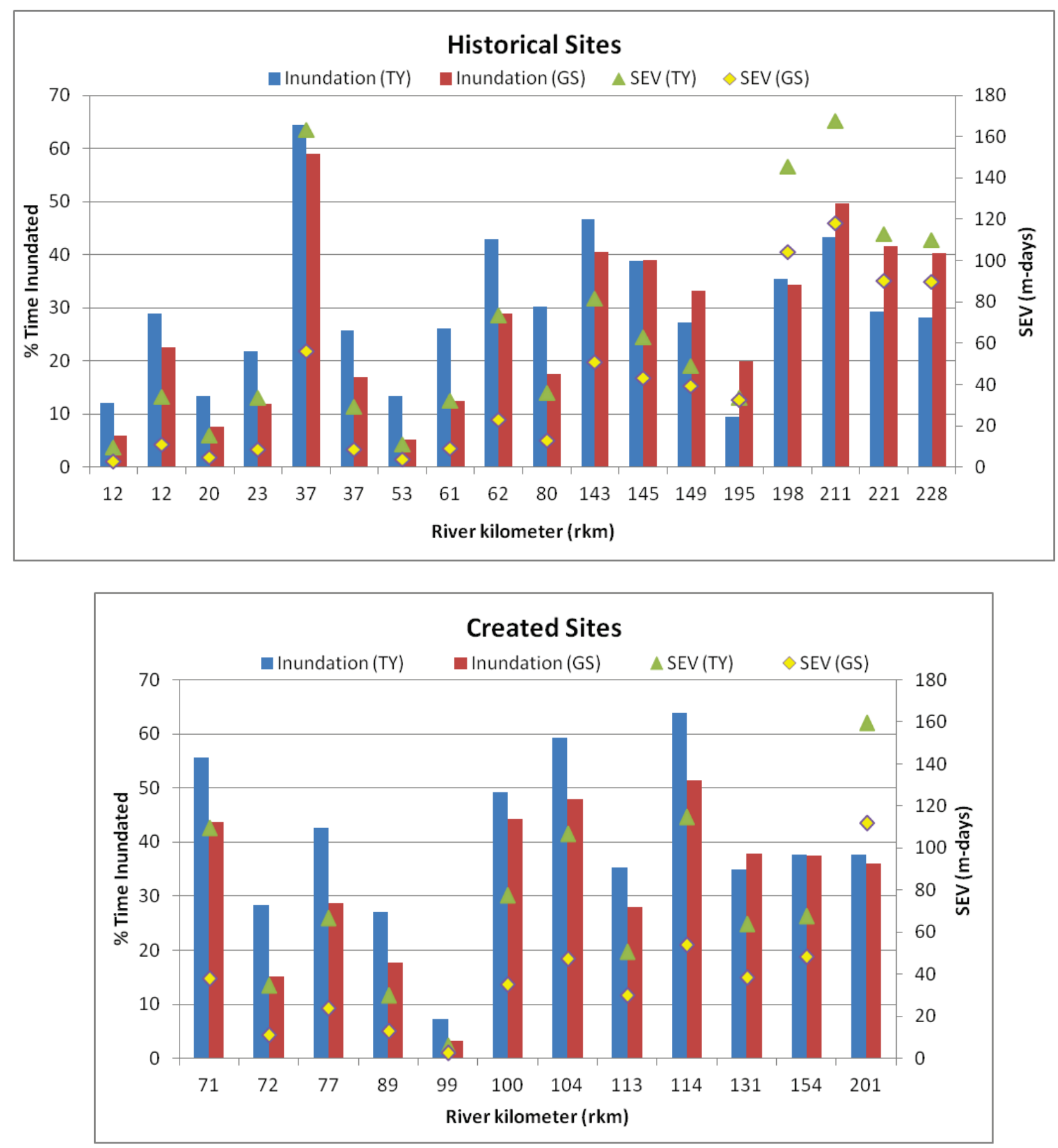

Figure 16. Inundation frequency and sum exceedence value (SEV) of the average marsh elevation during the total year (TY) and the growing season (GS) at historical sites (top) and created sites (bottom). 


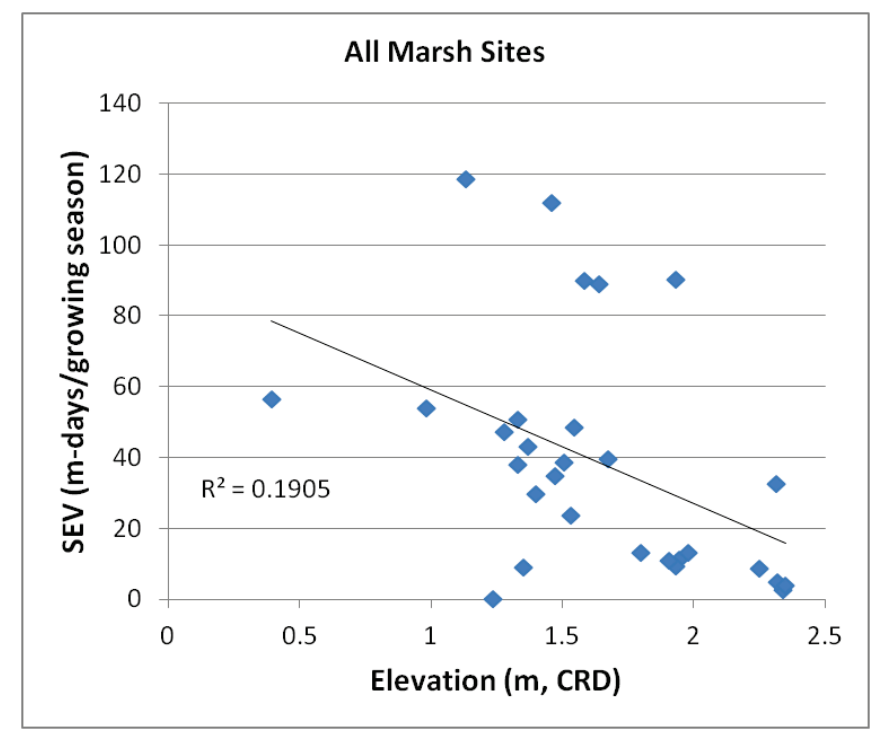

Figure 17. Sum exceedance value (SEV) related to elevation for all created and historical marsh sites in the analysis.
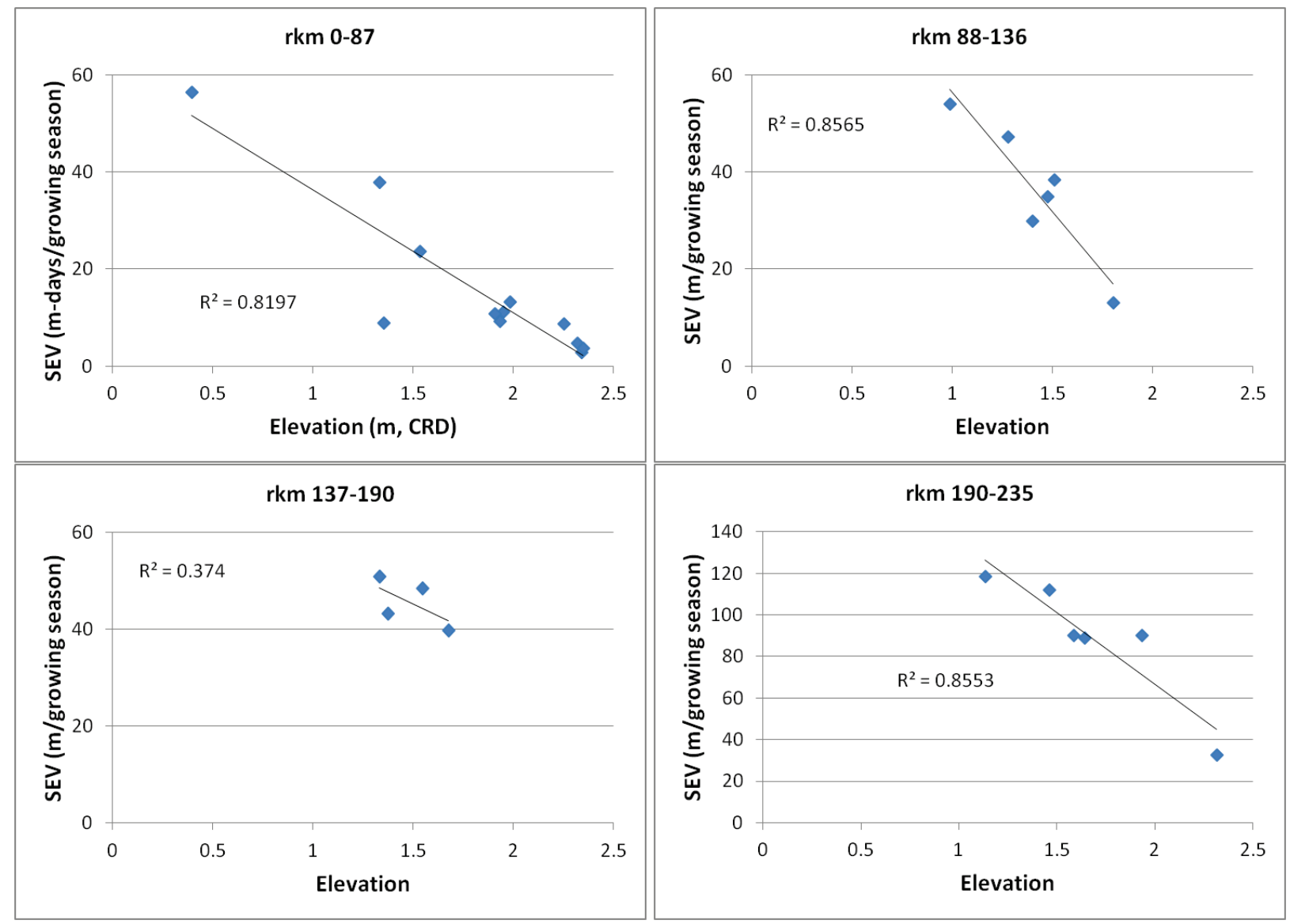

Figure 18 Sum exceedance value (SEV) for the growing season related to elevation for created and historical marsh sites within hydrologic zones of the CRE. 


\subsubsection{Vegetation Assemblage Structure}

This analysis focused on broad patterns of vegetation distribution along the estuarine gradient and the relationship of those patterns to elevation. We focus much of our analysis on reed canary grass (Phalaris arundinacea), a highly invasive species, to increase understanding regarding the spatial extent and prevalence of the species and to provided information that may ultimately help improve management of the species. In this analysis, 172 taxa were observed: 115 in created marshes and 139 in historic marshes. Seven taxa made up $68 \%$ of the cumulative cover as shown in Table 10. Reed canary grass occurred in 52 percent of the quadrats and accounted for 28 percent of the cover at all emergent marsh sites.

Table 10. Dominant taxa in terms of percent cover in 37 historical and created marsh sites in the LCRE.

\begin{tabular}{llccc}
\hline Scientific Name & Common Name & $\begin{array}{c}\text { Species } \\
\text { Code }\end{array}$ & $\begin{array}{c}\text { Percent } \\
\text { Cover }\end{array}$ & Cumulative Cover \\
\hline Phalaris arundinacea & Reed canary grass & PHAR & $28 \%$ & $28 \%$ \\
\hline Eleocharis palustris & Common spikerush & ELPA & $21 \%$ & $49 \%$ \\
\hline Sagittaria latifolia & Wapato & SALA & $10 \%$ & $59 \%$ \\
\hline Carex lyngbyei & Lyngby sedge & CALY & $3 \%$ & $62 \%$ \\
\hline Elodea canadensis & Canada waterweed & ELCA & $2 \%$ & $64 \%$ \\
\hline Ludwigia palustris & False loosestrife & LUPA & $2 \%$ & $66 \%$ \\
\hline Carex obnupta & Slough sedge & CAOB & $2 \%$ & $68 \%$ \\
\hline
\end{tabular}

Along the estuarine gradient from the mouth to the dam, the number of species present at a site is generally greatest in the lower-middle portion of the LCRE (rkm 53 - 89; Figure 19). Likewise, the greatest number and percent cover of non-native species were generally found in this portion of the estuary, although percent cover was high up to rkm 154. High non-native cover is primarily $P$. arundinacea. Lower species diversity at the lower and upper reaches of the LCRE is likely due to the effects of higher physical disturbance at these extremes. In the lower portions, a limited number of species can tolerate the hydrologic patterns resulting from daily tidal fluctuations. Likewise, at the upper end of the estuary, high fluvial dominance results in high inundation for part of the growing season, limiting the species that can tolerate this extreme condition. 

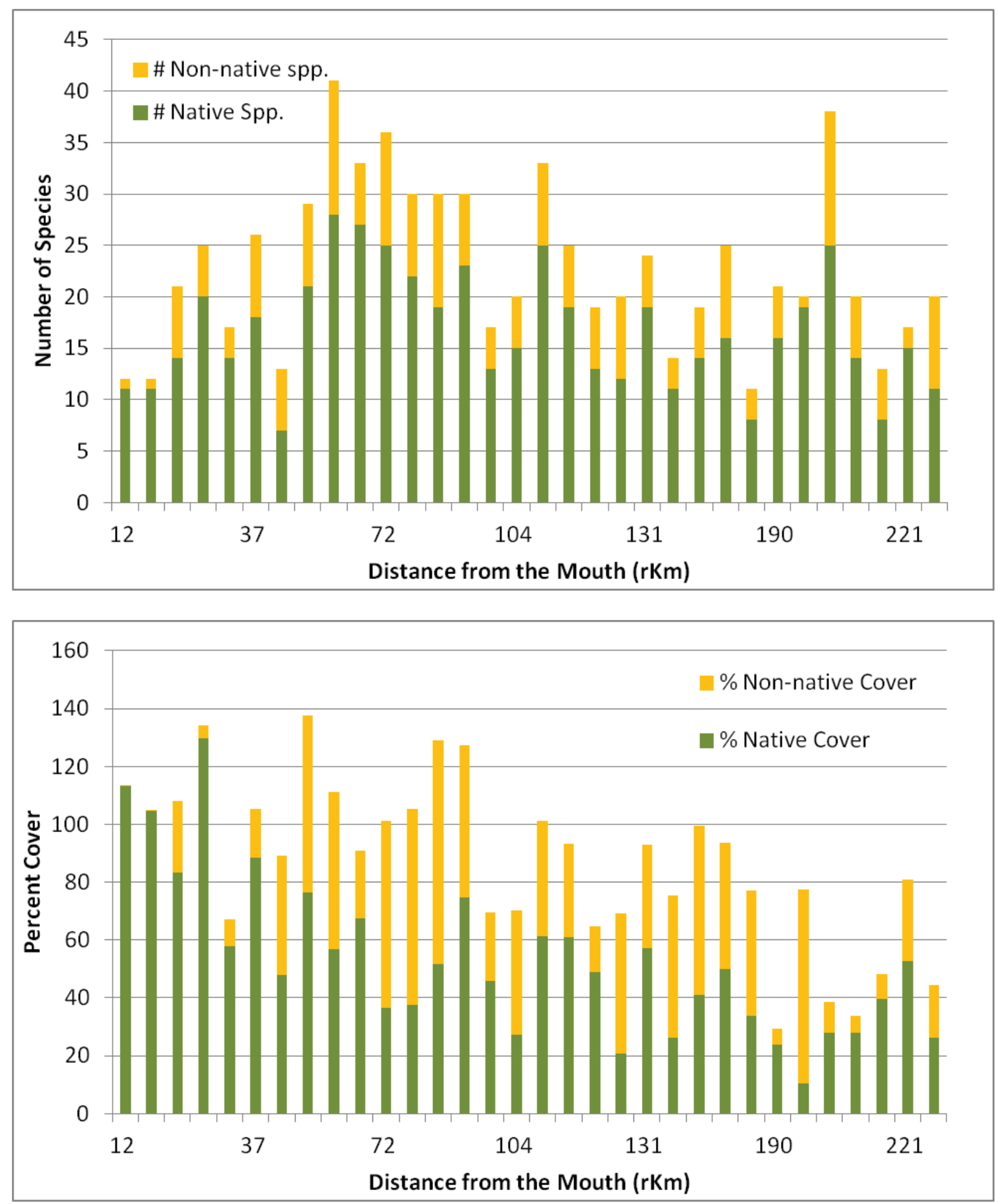

Figure 19. Number of species at each site (top) and average percent cover (bottom) of native and nonnative species at all marsh sites in the study area. 


\subsubsection{Vegetation Elevation Interactions}

The elevations of emergent marshes in the LCRE cover a narrow range. The sample areas at our sites were generally representative of this range, with $90 \%$ of the quadrats between $0.8 \mathrm{~m}$ and $2.6 \mathrm{~m}$ at historical sites and between $0.8 \mathrm{~m}$ and $2.0 \mathrm{~m}$ at created sites (Figure 20). Within this elevation range, the number of wetland species varies with the greatest number observed between $1.5 \mathrm{~m}$ and $2.5 \mathrm{~m}$ (Figure 21). The elevation of the maximum number of species was slightly higher in historical sites than in created sites.
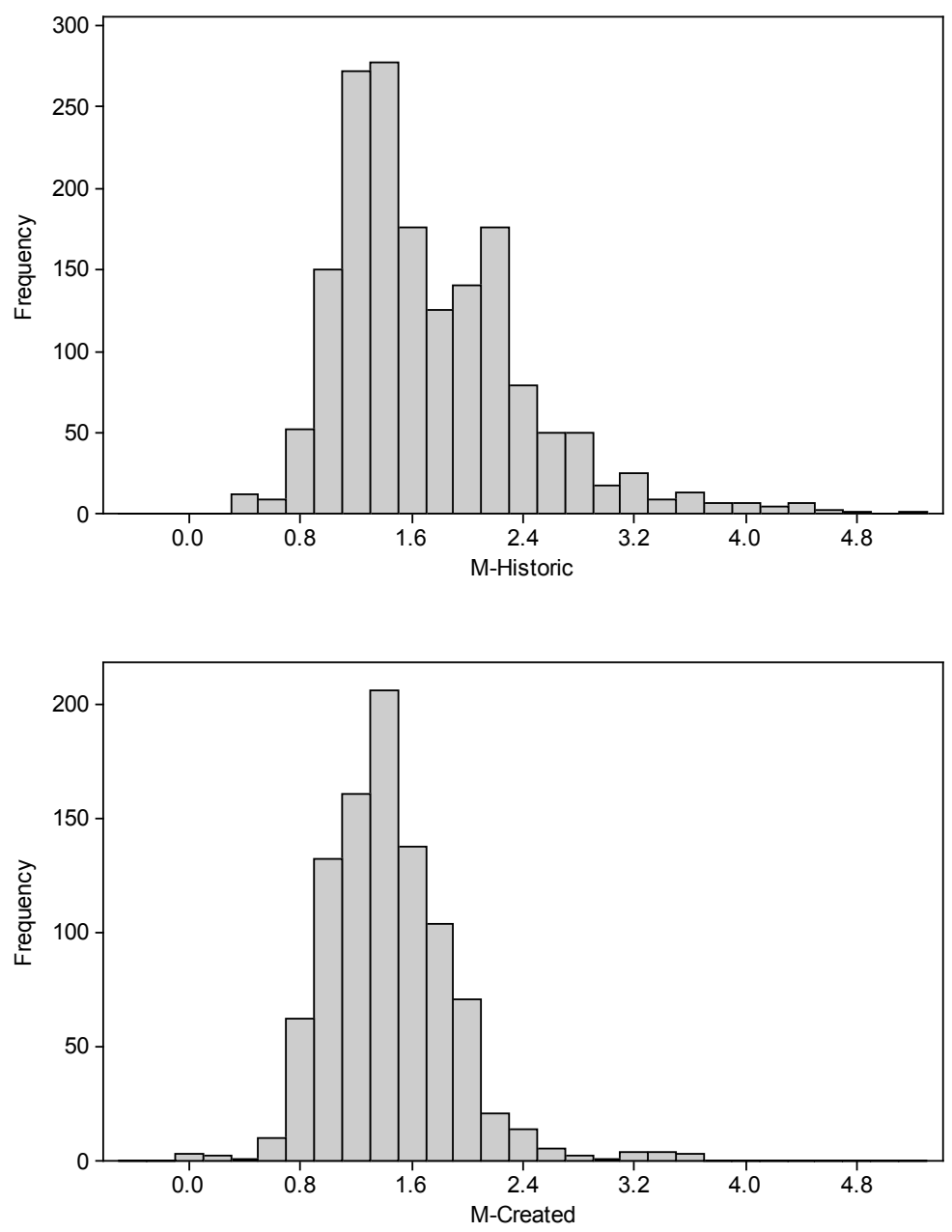

Figure 20. Frequency of vegetation quadrats at elevations (m, CRD) found in historical and created marshes in this analysis. 

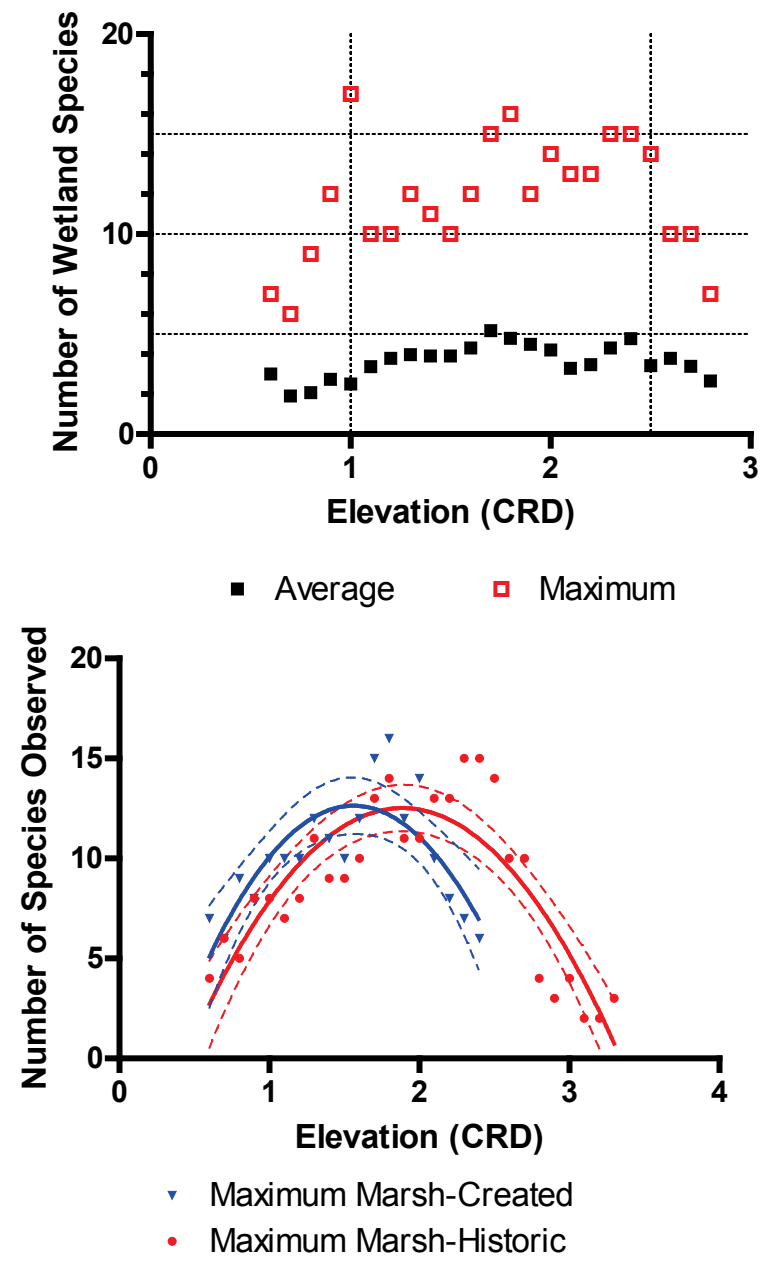

Figure 21. Average and maximum number of species observed at all marsh sites in the study area (top) and maximum number of species at historical and created marsh sites (bottom) by elevation (m, CRD).

The distribution of the common emergent marsh species within the elevation gradient is shown in Figure 22. The three most common species, Sagittaria latifolia (SALA), Eleocharis palustris (ELPA), and $P$. arundinacea (PHAR) cover distinct elevation ranges. The minimum elevation for PHAR was evaluated more closely in an effort to identify areas where other species may be able to out-compete this invasive species. Figure 23 indicates that in historical sites the lowest elevation where PHAR has the maximum cover in a quadrat is approximately $1.6 \mathrm{~m}$. At created sites, this elevation varies more along the estuarine gradient, from approximately 1.4 to $1.8 \mathrm{~m}$. 


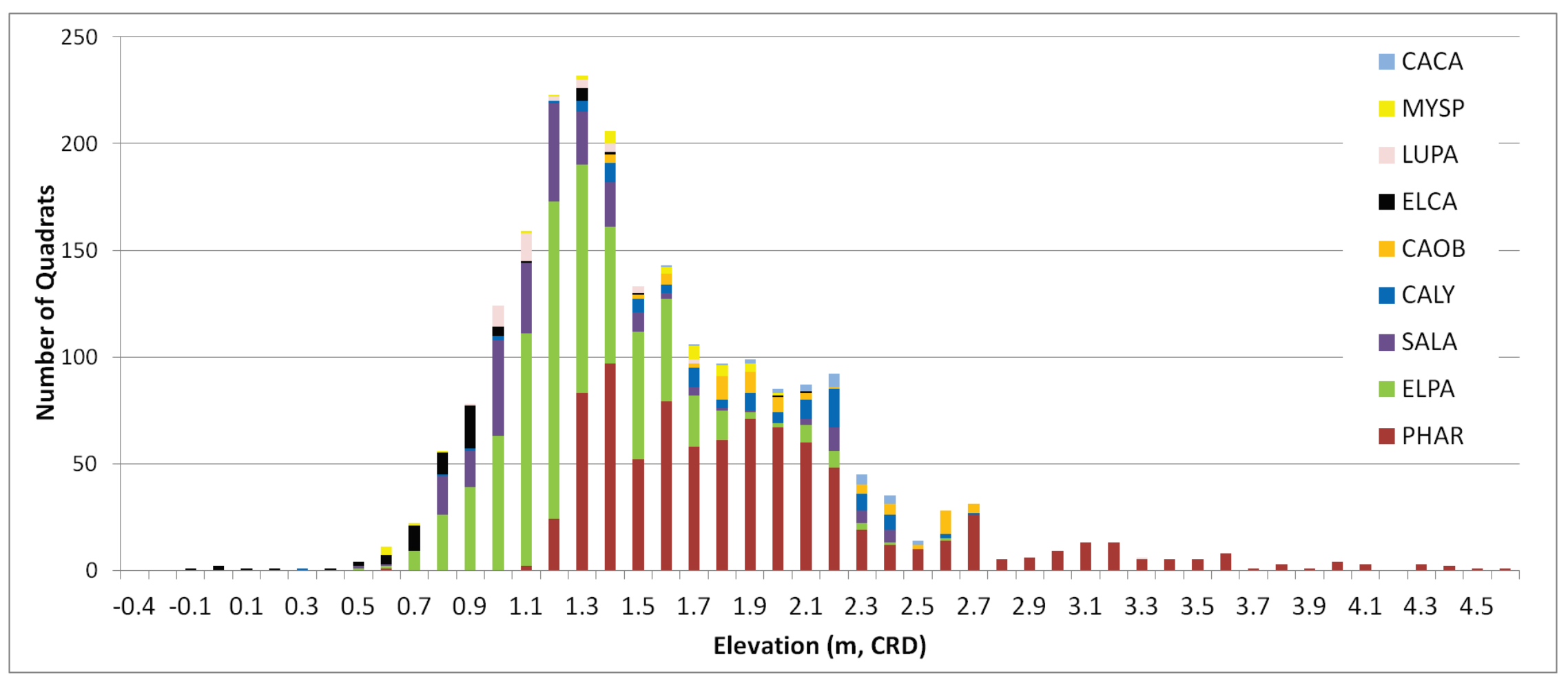

Figure 22. Number of quadrats at each elevation where the common marsh species were observed to have greater than $20 \%$ cover (elevation in meters relative to $\mathrm{CRD}$ ). 


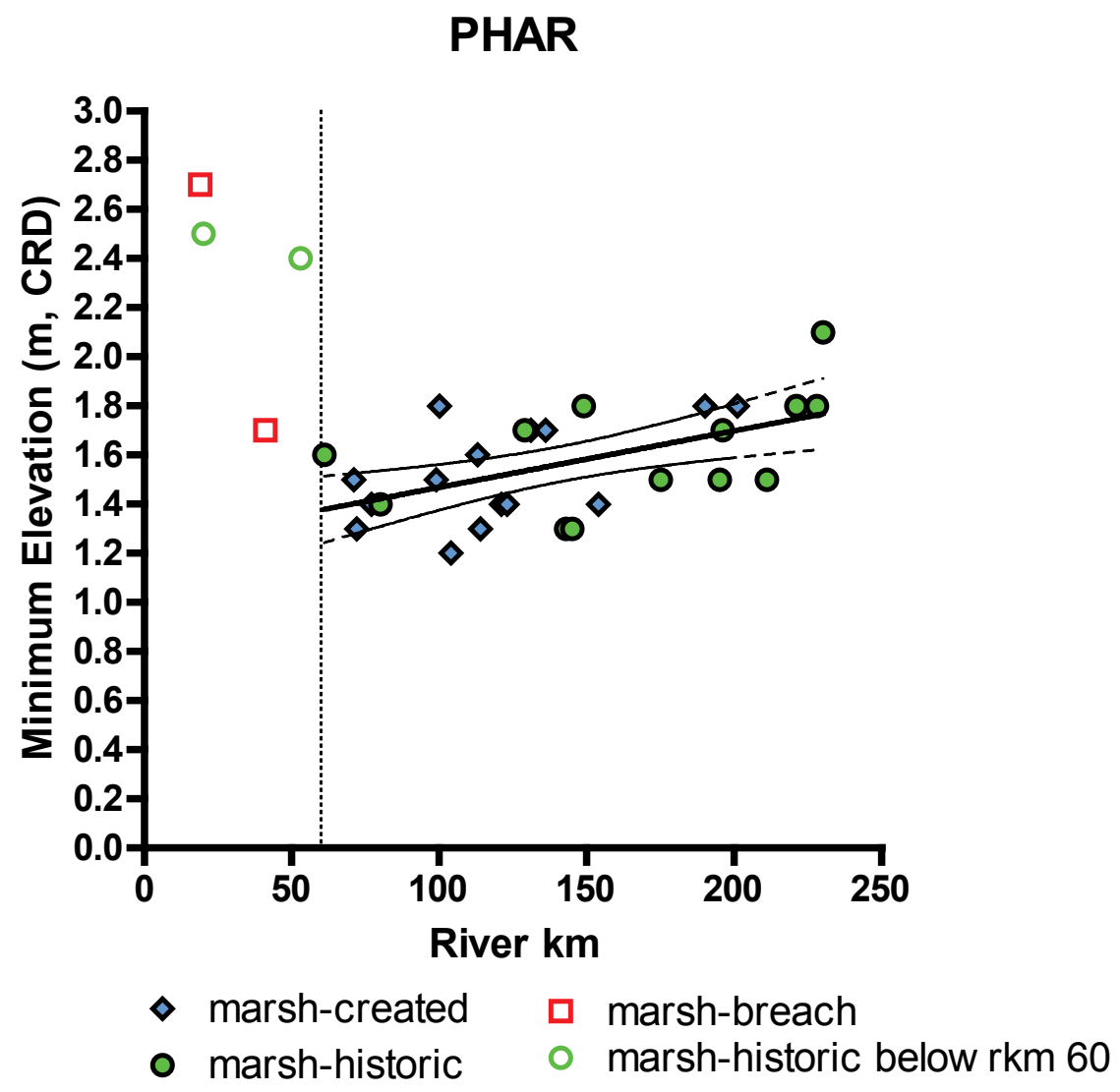

Figure 23. Minimum elevation ( $\mathrm{m}, \mathrm{CRD}$ ) of reed canary grass (Phalaris arundinacea [PHAR]) at sites along the longitudinal gradient of the river. Regression line and $95 \%$ confidence limits (dashed lines) are shown for created and historic marshes above rkm 60.

\subsubsection{Elevation, Inundation, and Vegetation Interactions}

Hydrology is one of the primary factors controlling the presence and distribution of wetland vegetation (Mitsch and Gosslink 2000). The variation in inundation patterns observed throughout the LCRE is directly related to patterns in total wetland vegetation cover (Figure 24). The SEV during the growing season varies from low values in the tidally dominated portion of the estuary to high values in the fluvial dominated portion. During the time at which we sample (late July - early August), the vegetation cover is high in the tidal portion and low in the fluvial portion. This relationship is caused by the high inundation from the spring freshet stressing the plants and reducing their productivity. The timing, duration, and magnitude of the freshet likely determine the extent of the stress and the timing of recovery. Perhaps the plants in the fluvial dominated regions have higher cover later in the growing season but whether the cover is comparable to that seen in the more tidally dominated areas has not been determined due to the limit of our sampling period (late July to early August). Interannual variability in the cover related to inundation variations is discussed in Section 3.3.3 below. 

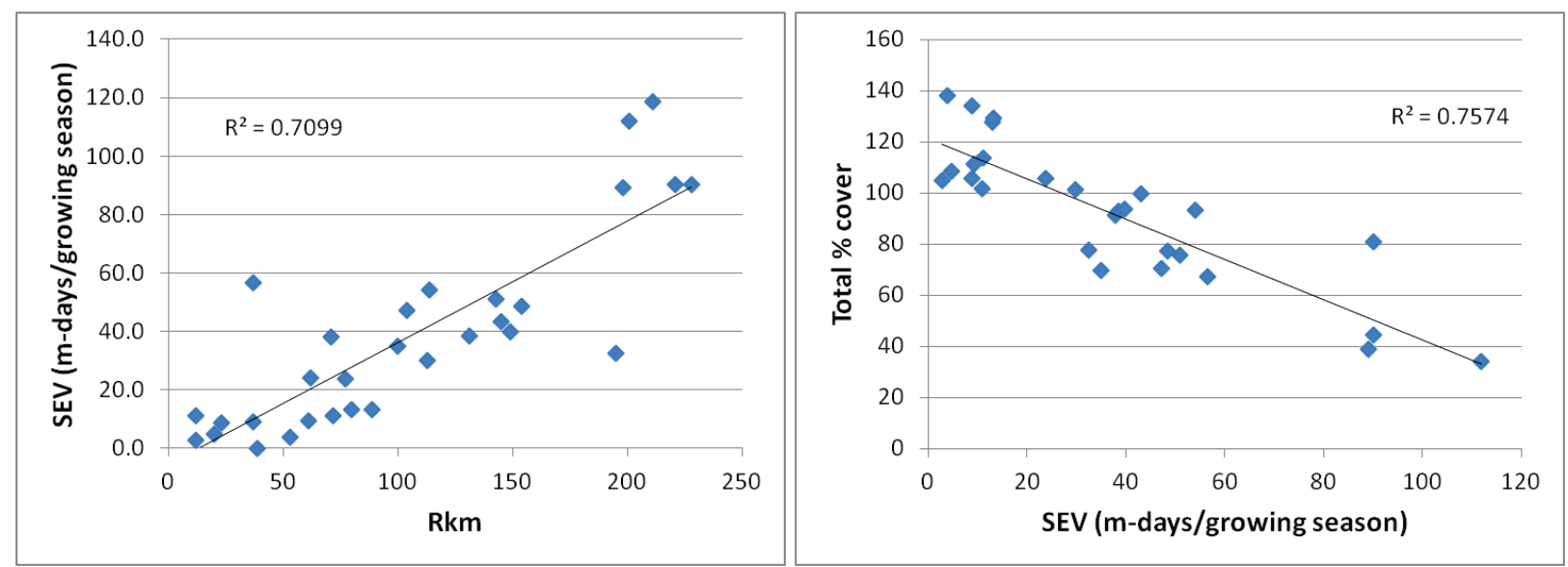

Figure 24. Sum exceedance value (SEV) as related to longitudinal gradient of the river (left panel) and total percent vegetation cover related to SEV (right panel).

\subsubsection{Channel Morphology and Inundation}

Channel morphology and inundation are important factors in the evaluation of potential for fish to access tidal wetlands areas for feeding, rearing, and cover. We have seen that inundation patterns vary along the estuarine gradient (Figure 24), likewise the channel morphology changes as well. Figure 25 shows a general change in average channel depth with deeper channels in the lower estuary becoming shallower in the upper estuary. Exceptions to this trend are found at the created sites, where most of the created sites tend to be shallower than the historical sites. However, two of the created sites (LI1 and GIC) have some of the deepest channels. These conditions can be explained by considering the history of the sites. The generally shallow nature of the channels at created sites could be due to the limited time the sites have been exposed to the channel-forming processes compared to the historically present sites. Alternatively, lower bank elevations of the created sites could also explain the shallower depth. At the created sites with greater depth, the explanation is perhaps that the method of dredge material placement produced higher channel banks. 


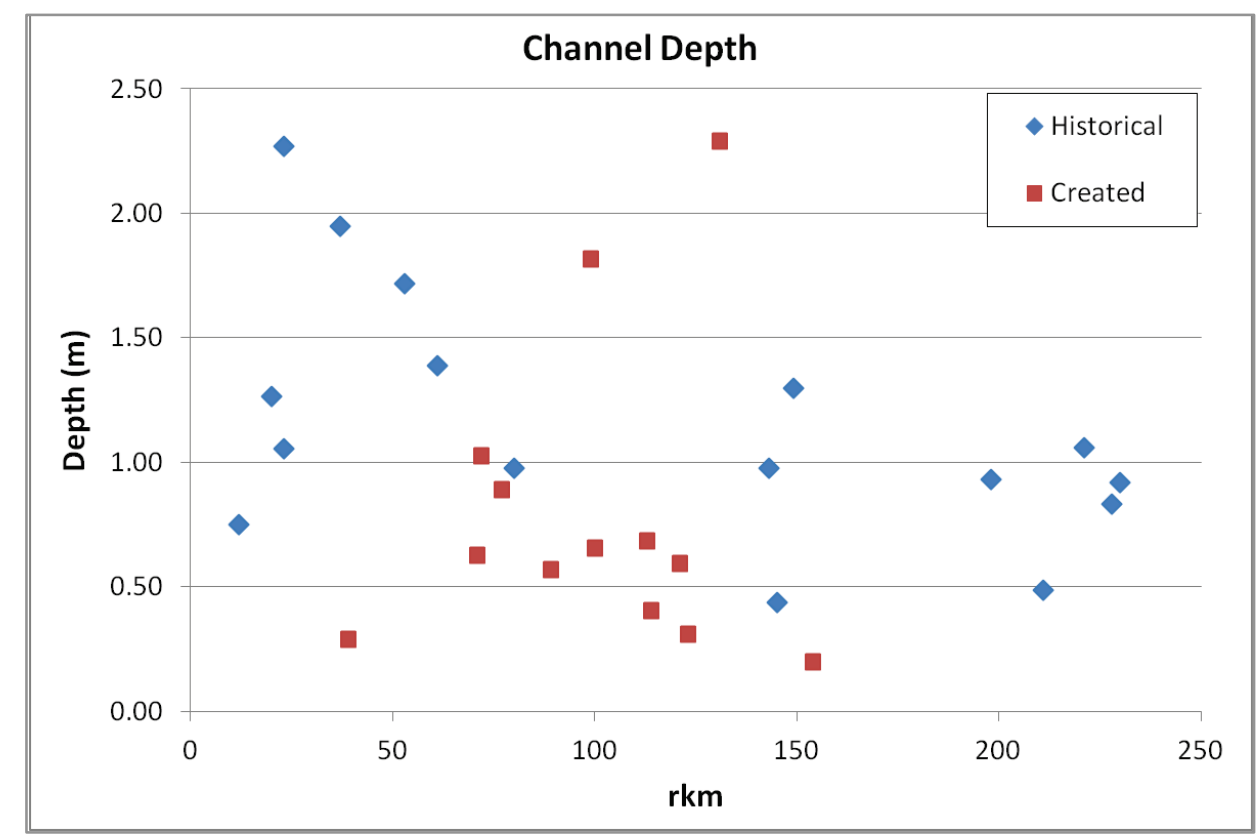

Figure 25. Average channel depth for the primary marsh channel at historical and created sites included in this analysis.

Frequency of inundation at the channel mouth is an indication of the opportunity for juvenile fish access to the tidal channel and the marsh. The frequency was calculated using the thalweg elevation with $50 \mathrm{~cm}$ of water as an estimate of the amount of water needed for fish to enter the channel. In general, the frequency of inundation provides access to the channel between 50 and 80 percent of the time in most areas of the LCRE (Figure 26). In the lower, tidally dominated part of the estuary, this frequency is consistent during the peak salmon migration period (FW) and the whole year (TY). In contrast, in the upper estuary the amount of time the channel is accessible decreases during the TY due to the low water period that occurs in the fall. A few sites are inundated greater than 90 percent of the time, caused either by deep channels at the mouth (WIM, LI1, CI1) or the presence of perennial streams (SBM, HCM). CLM is not included because no data were collected at the channel mouth for that site and FLM is not included because beaver dams affected the water level at the sensor so the data was not representative of conditions at the mouth. In the latter case, a sensor would need to be placed below the beaver dam in order to accurately determine the inundation frequency at this location.

Frequency of inundation at the channel bank is a useful metric for evaluating amount of time juvenile salmon would have access the marsh interface for feeding and cover. In the lower estuary (below rkm 60), the channel bank (with $10 \mathrm{~cm}$ of water) was accessible 20 to 30 percent of the time during the TY and the FW periods. Above RIM (61 rkm) the frequency increased to about 30 to 60 percent of the time.

Inundation frequencies in the middle reaches of the estuary ( rkm $61-140)$ were calculated primarily at the created sites which had greater inundation frequencies in part due to lower bank elevations. The greater inundation above SBM (rkm 143) during the FW was primarily due to the influence of higher water levels during the spring freshet. The lowest inundation frequencies were observed at GIC and HCM, both of which have high channel bank elevations. Greatest overall frequency of inundation during the FW period was at 3 created sites (i.e., CI1, CI2, and SSC) providing frequent access to the channel $(100,79$, and 78 percent, respectively) and to the bank (71, 86, 68 percent, respectively). 

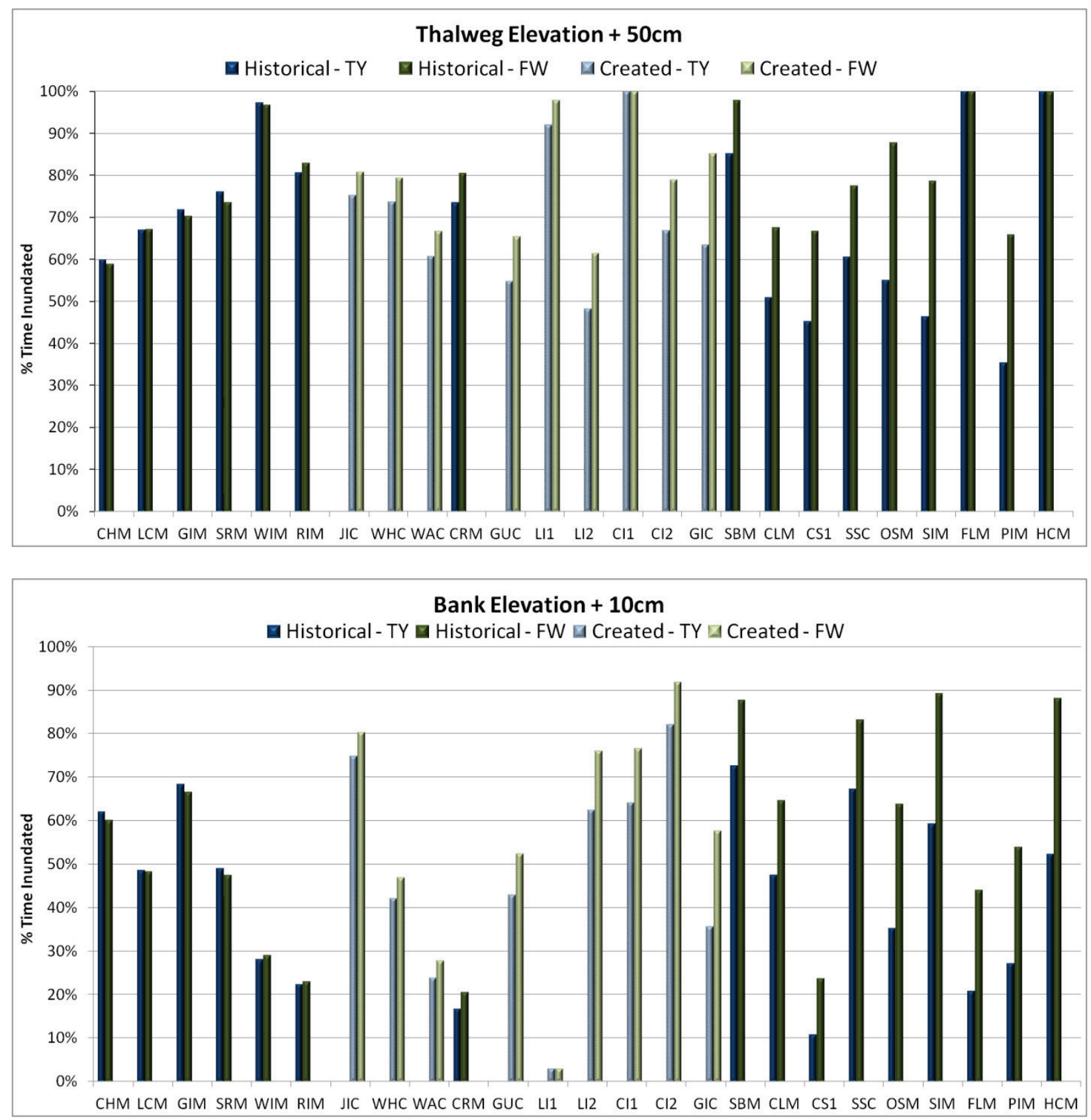

Figure 26. Inundation frequency at the channel mouth cross-section for the thalweg elevation $(+50 \mathrm{~cm})$ and for the average channel bank elevation $(+10 \mathrm{~cm})$ during the total year $(\mathrm{TY})$ and the peak fish migration period (FW). 


\subsection{Trends Analysis}

A temporal analysis of vegetation species composition, vegetation cover, and inundation patterns was previously conducted at three of the core sites: Cunningham Lake (CLM, rkm 145) and Campbell Slough (CS1, rkm 149) for the years 2005-2009 and Franz Lake (FLM, rkm 221) for 2008-2009 (Borde et al., $2011 \mathrm{~b}$ ). Herein, this analysis is extended to include data from the most recent monitoring years of 2010 and 2011 and to include the relevant data from an additional core site, Whites Island (WHC, rkm 72) from 2009-2011. In addition, we compared the accretion rates and channel morphology at the four sites for the years monitored between 2008 and 2011.

\subsubsection{Hydrology Patterns}

The Columbia River basin is primarily a snow-melt runoff watershed and as such is subject to interannual hydrologic variability. Figure 27 shows the variation in the timing and magnitude of outflow at Cascade Island, just below Bonneville dam for the years 2005-2011 and is provided here to give an overview of the hydrological patterns for the estuary during this study. In general, 2006, 2008, and 2011 were high flow years, 2005 and 2007 were lower flow years, and 2009 and 2010 average flow years as compared to the 10-year average flow (2000-2009).

\subsubsection{Sediment Accretion Rate}

Sediment accretion rates at the four core sites vary between $-1.2 \mathrm{~cm} /$ year (erosion) and $3.0 \mathrm{~cm} /$ year (accretion) (Table 11). These differences are likely due to a combination of factors at the sites including vegetation, elevation, and flooding impacts. The variability in the rates at WHC between 2008-09 and 2009-2010 may be in part due to a change in vegetation at the location of the stakes. Observations at the time of measurements indicate that in 2009 a $6 \mathrm{~cm}$ thick mat of forget-me-not (Myosotis scorpioides) may have caused difficulties in determining the true sediment surface. Over the years, the vegetation has shifted to include more reed canary grass (Phalaris arundinacea). The highest rate was measured at FLM in 2011, which would be expected following the extended high water period at this site. Likewise, rates greater than $1.0 \mathrm{~cm} /$ year were also observed at CS1 and CLM where the high water likely increased sedimentation rates also.

Table 11. Sediment accretion rates at the core sites between 2008 and 2011.

\begin{tabular}{rrlrl}
\hline & WHC & CS1 & CLM & FLM \\
\hline & & \multicolumn{2}{l}{ Rate (cm/year) } \\
$\mathbf{0 8 - 0 9}$ & -1.2 & ND & ND & 0.5 \\
$\mathbf{0 9 - 1 0}$ & 1.0 & 0.4 & 1.9 & ND \\
$\mathbf{1 0 - 1 1}$ & 0.1 & 1.7 & 1.6 & 3.0 \\
\hline
\end{tabular}



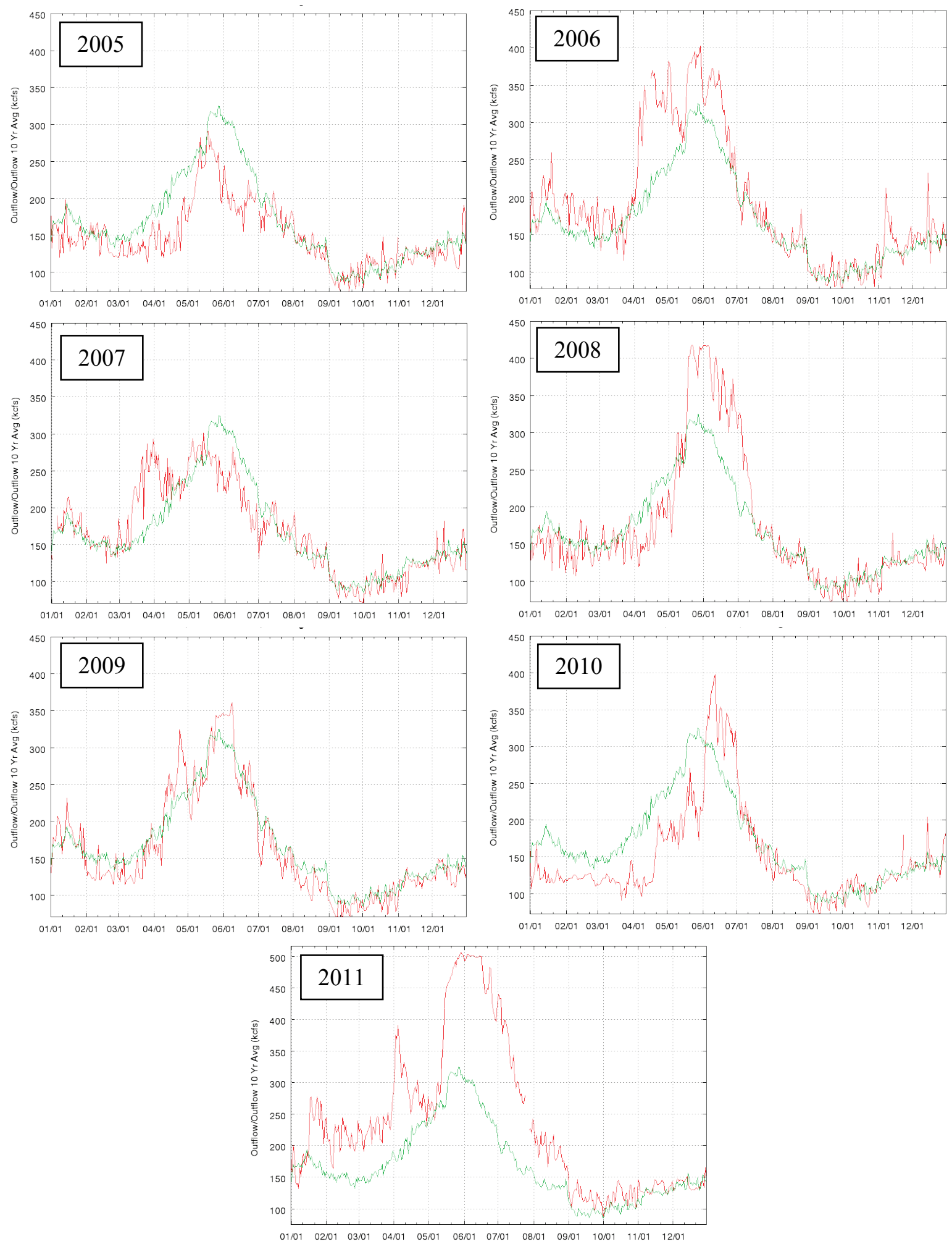

Outlow -

Outlow 10YrAva -

Figure 27. Daily mean outflow (red line) at Bonneville dam compared to the 10-year average (2000-2009; green line) for the years 2005-2011. Note the slightly larger scale for 2011. Data from Columbia River DART website (http://www.cbr.washington.edu/dart/river.html). 


\subsubsection{Vegetation and Elevation}

Overall, the vegetation composition at the four sites was similar in all monitoring years; however, a weighted similarity index comparing all years at each site shows there to be some variability between years. One way to evaluate similarity over time is to compare the original year of monitoring to the following years. WHC became less similar to its original monitored state (2009) over the three years, although a longer record will be necessary to determine if this trend continues. At CLM, the trend over time was consistent in that the high water years (2008 and 2011) were the least similar to the low-flow starting year (2005). At the CS site, the trend is not as clear. In 2007, cows were present at the CS site resulting in grazing and trampling of some of the vegetation and as expected, this year is the least similar to the original year. Likewise, 2007 was most similar to the high water years at this site, which also cause a disturbance to the vegetation. Similarity at FLM was consistent over the three years monitored at the site.

\begin{tabular}{||r|r|r||}
\multicolumn{3}{c|}{ WHC } \\
\hline & $\mathbf{2 0 0 9}$ & $\mathbf{2 0 1 0}$ \\
\hline $\mathbf{2 0 1 0}$ & 74.4 & \\
\hline $\mathbf{2 0 1 1}$ & 64.0 & 73.8 \\
\hline
\end{tabular}

CLM

\begin{tabular}{||r|r|r|r|r|r|r||}
\hline \hline $\mathbf{2 0 0 6}$ & $\mathbf{2 0 0 5}$ & $\mathbf{2 0 0 6}$ & $\mathbf{2 0 0 7}$ & $\mathbf{2 0 0 8}$ & $\mathbf{2 0 0 9}$ & $\mathbf{2 0 1 0}$ \\
\hline $\mathbf{2 0 0 7}$ & 72.6 & & & & & \\
\hline $\mathbf{2 0 0 8}$ & 68.2 & 71.4 & 83.2 & & & \\
\hline $\mathbf{2 0 0 9}$ & 72.1 & 63.9 & 80.9 & 74.4 & & \\
\hline $\mathbf{2 0 1 0}$ & 72.5 & 71.5 & 77.3 & 76.9 & 79.0 & \\
\hline $\mathbf{2 0 1 1}$ & 53.1 & 69.1 & 57.0 & 63.9 & 57.5 & 61.1 \\
\hline
\end{tabular}

CS1

\begin{tabular}{||l|l|l|l|l|l|l||}
\hline \hline & $\mathbf{2 0 0 5}$ & $\mathbf{2 0 0 6}$ & $\mathbf{2 0 0 7}$ & $\mathbf{2 0 0 8}$ & $\mathbf{2 0 0 9}$ & $\mathbf{2 0 1 0}$ \\
\hline $\mathbf{2 0 0 6}$ & 75.8 & & & & & \\
\hline $\mathbf{2 0 0 7}$ & 62.5 & 64.7 & & & & \\
\hline $\mathbf{2 0 0 8}$ & 68.4 & 71.3 & 77.9 & & & \\
\hline $\mathbf{2 0 0 9}$ & 72.5 & 64.6 & 60.9 & 66.9 & & \\
\hline $\mathbf{2 0 1 0}$ & 69.6 & 62.7 & 66.7 & 65.6 & 82.1 & \\
\hline $\mathbf{2 0 1 1}$ & 71.8 & 73.1 & 71.6 & 76.3 & 68.9 & 70.3 \\
\hline
\end{tabular}

FLM

\begin{tabular}{|r|r|r|}
\hline & $\mathbf{2 0 0 8}$ & $\mathbf{2 0 0 9}$ \\
\hline $\mathbf{2 0 0 9}$ & 71.0 & \\
\hline $\mathbf{2 0 1 1}$ & 71.5 & 74.1 \\
\hline
\end{tabular}

Figure 28. Similarity analysis results between years for the four core monitoring sites. 
Vegetation cover and the number of species present are the two primary factors contributing to the similarity variability observed at the sites over time. Figure 29 shows the average percent cover of the dominant species, the number of species, and the variation between years. WHC is the farthest down-river site and therefore the least affected by hydrologic variability. The site is the most diverse site, with the number of species ranging from 33 to 38 between years. Overall cover at WHC decreased by 14 percent while Phalaris arundinacea (PHAR) increased by 10 percent over the three year period. The trends at CLM and CS1 are similar to each other, with the exception of 2007 at CS1, where lower cover occurred during the higher water years $(2006,2008$, and 2011). CLM had a lower cover in 2011 than CS1 perhaps due to the higher elevation of the CS1 site being exposed earlier than the CLM site. The trend is similar at FLM, with lower cover in the two high water years. Likely, the cover would have been even lower in 2011 if the site was sampled in late, however the water was still too high to sample at that time and was sampled one month later. To further evaluate the effect of hydrology on vegetation cover, we compared the vegetation to the hydrologic patterns in each year as described below.

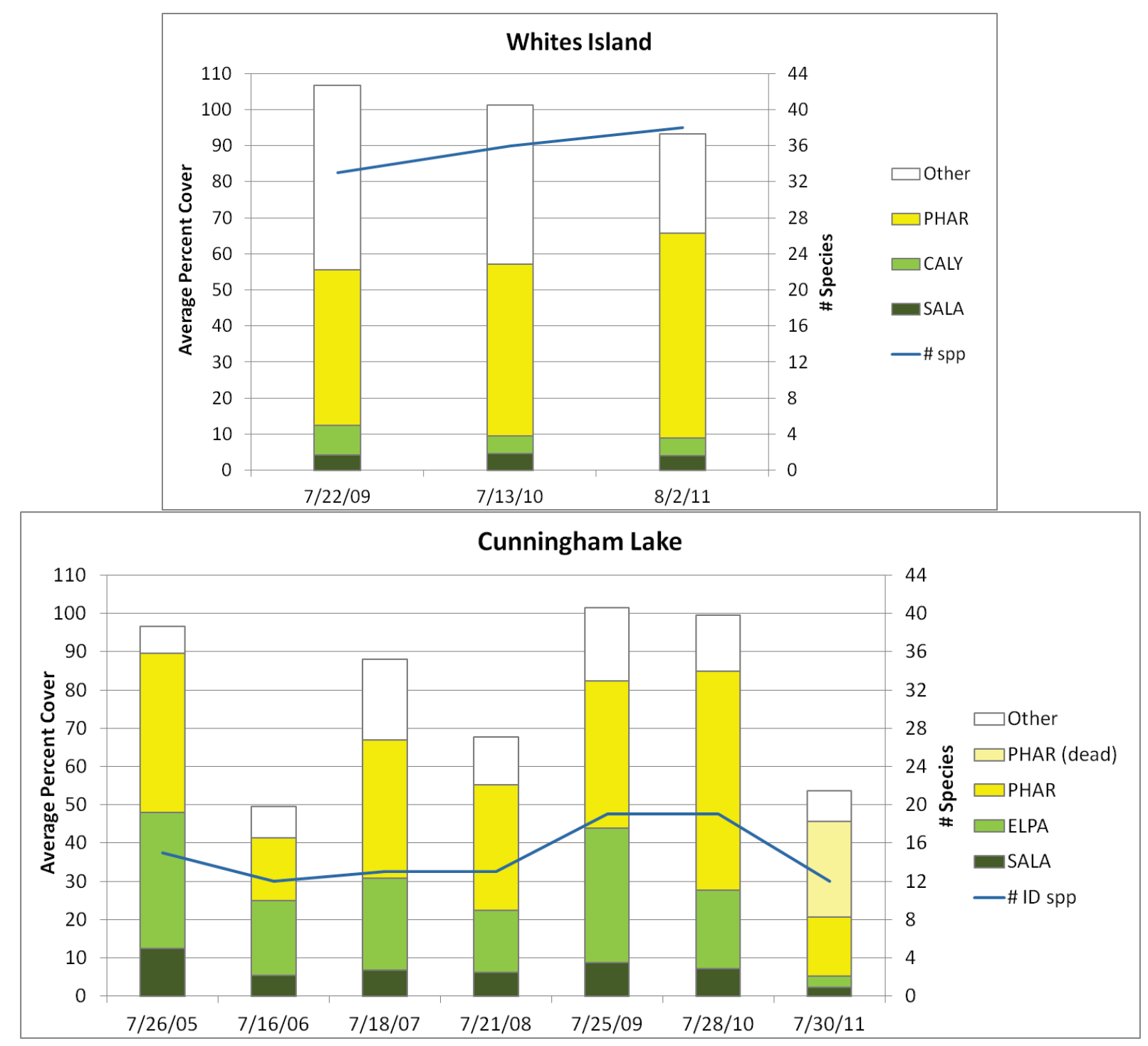

Figure 29. Average percent cover and number of identified species at the core sites for all years monitored. 

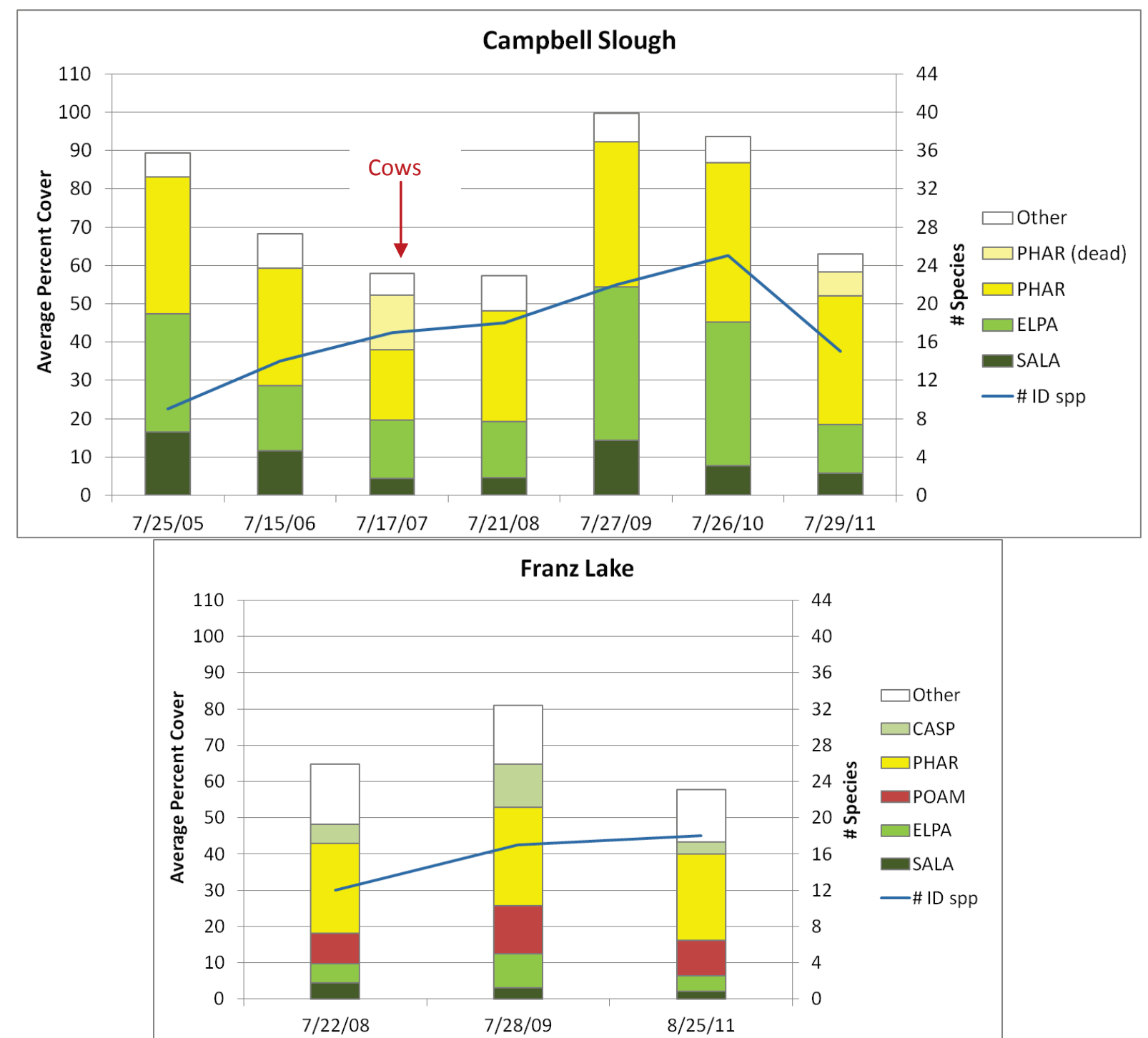

Figure 29. (Continued).

The upper and lower limits of the dominant species were evaluated in the previous trends analysis at CS1 and CLM. The results indicated that the elevation boundaries were stable, with little variation between years. To evaluate this finding further, we extended the analysis to include recent years and the WHC and FLM sites (Figure 30). We compared the 2011 elevations to the average elevation of the lower and upper boundaries for each species to determine if the hydrologic increase caused a change in the boundaries outside the range seen in the previous years. Higher variability occurred at WHC likely due to the greater heterogeneity of elevations at the site due to steep cut-banks. The variability associated with the lower elevation of Sagittaria latifolia (SALA) at FLM is likely due to the increased inundation from the beaver dam in 2009 and 2011 compared to that in 2008 when SALA was able to grow at a lower elevation. In general, the boundaries did not vary more in 2011 than they did in the previous years, with a few exceptions. There was a slight increase in the lower elevations for all three species at CLM, but not the upper limits indicating that indeed the plants were likely affected by the higher water. 

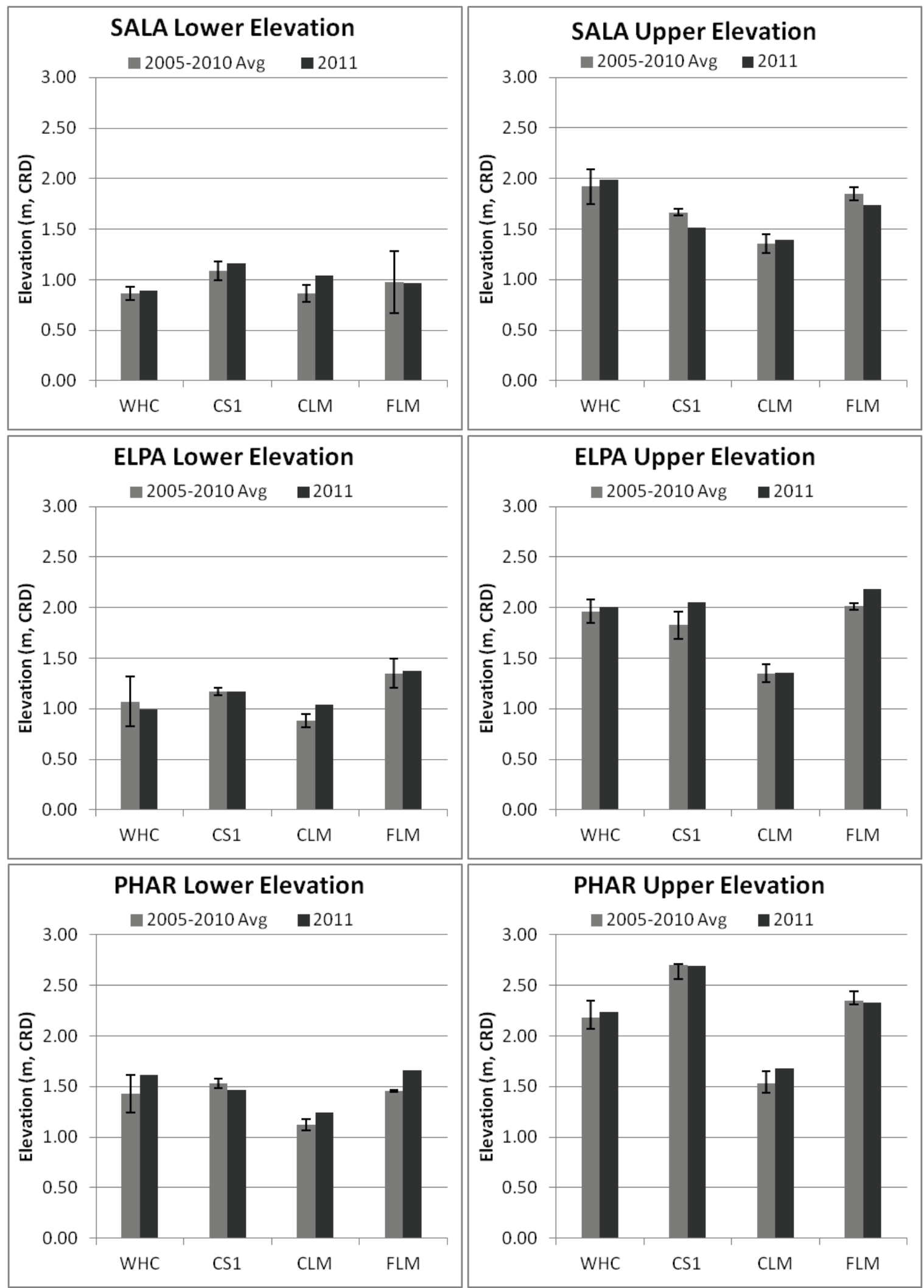

Figure 30. Lower and upper elevations for the dominant species at the core monitoring sites. Error bars on the 2005-2010 Average bars represent \pm standard deviation. 


\subsubsection{Vegetation Cover and Inundation}

Three study sites (FLM, CLM and CS1) were evaluated for interannual variability in vegetation cover and inundation. WHC was not included in this analysis because the hydrologic patterns do not vary at this site in the same way as it does at the up-river sites (see Figure 11). Three species comprise most of the vegetation cover at the study sites (five at FLM), so the SEV was calculated for the average elevation of each vegetation community, using the water levels measured each year during the growing season (Figure 31). The overall pattern at both sites is decreased vegetation cover with increased inundation as measured by the SEV. Interestingly, although there are differences in the elevations of some of the strata between sites, the SEV is very similar. For example, the average elevation of the $P$. arundinacea strata is $1.3 \mathrm{~m}$ and $2.0 \mathrm{~m}$ at CLM and CS1, respectively, and the SEV in 2011 was 165 and 163 at CLM and CS1, respectively.

While the relationship between cover and inundation held true for the most part, some exceptions require closer inspection. For example, the cover of $P$. arundinacea at CS1was higher than would have been expected in 2011 given the inundation levels that year. One possible explanation could be due to the higher elevation at this site compared to the others and the timing of the inundation relative to our sampling (e.g. areas of the strata exposed more recently). Also, the cover of Sagittaria latifolia at Franz Lake was actually higher in one of the high inundation years (2008) compared to the lower inundation year (2009), which could possibly be attributed to the beaver activity observed at the site causing more ponding and inundation in 2009 at the low elevations where $S$. latifolia grows.

\subsubsection{Channel Morphology}

Inter-annual variability of cross section morphology is low as seen by the comparison of single cross section locations from the repeat (core) sites. Elevation differences at Whites Island (WHC) between 2010 and 2011 are likely due to slightly different survey intervals; although some erosion at the channel thalweg is also possible. This site has much more tidal flow than the other up-river core sites which could potentially result in more channel scouring. 


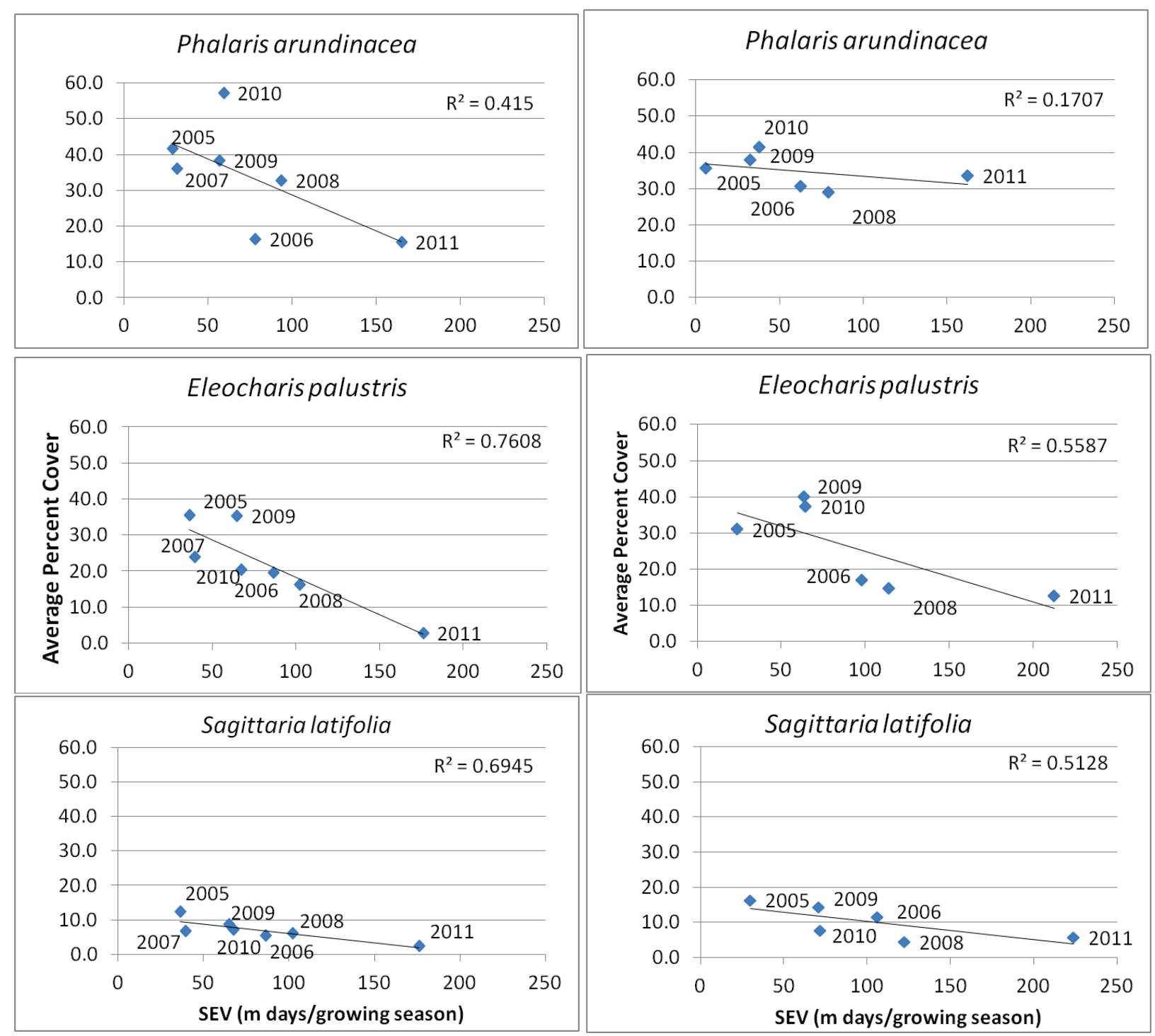

a) Cunningham Lake

b) Campbell Slough

Figure 31. Annual average percent vegetation cover of the dominant species at a) Cunningham Lake and b) Campbell Slough as related to annual growing season sum exceedance values (SEV) calculated at the average elevation for each species. 


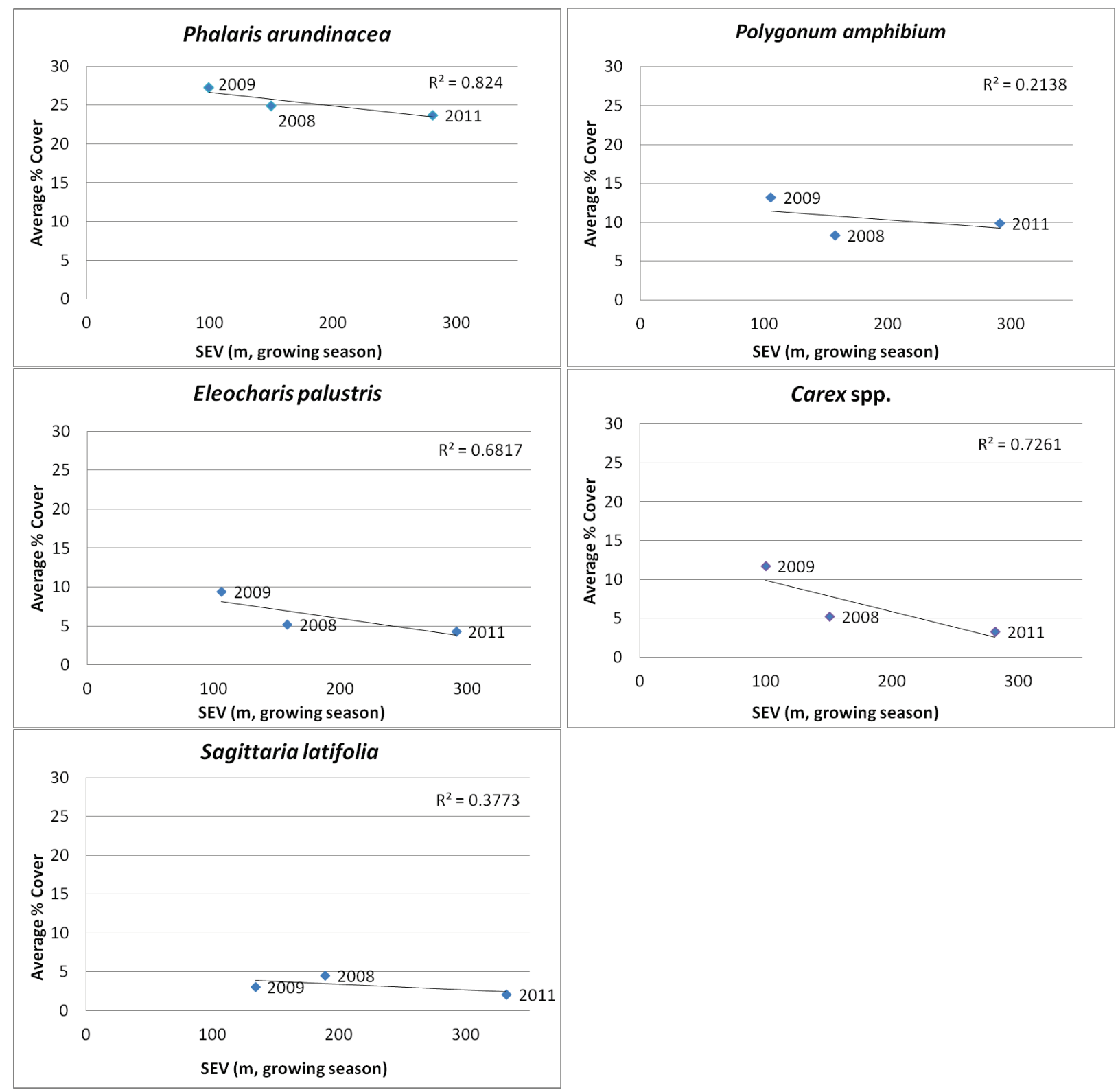

Figure 32. Annual average percent vegetation cover of the dominant species at Franz Lake as related to annual growing season sum exceedance values (SEV) calculated at the average elevation for each species. 


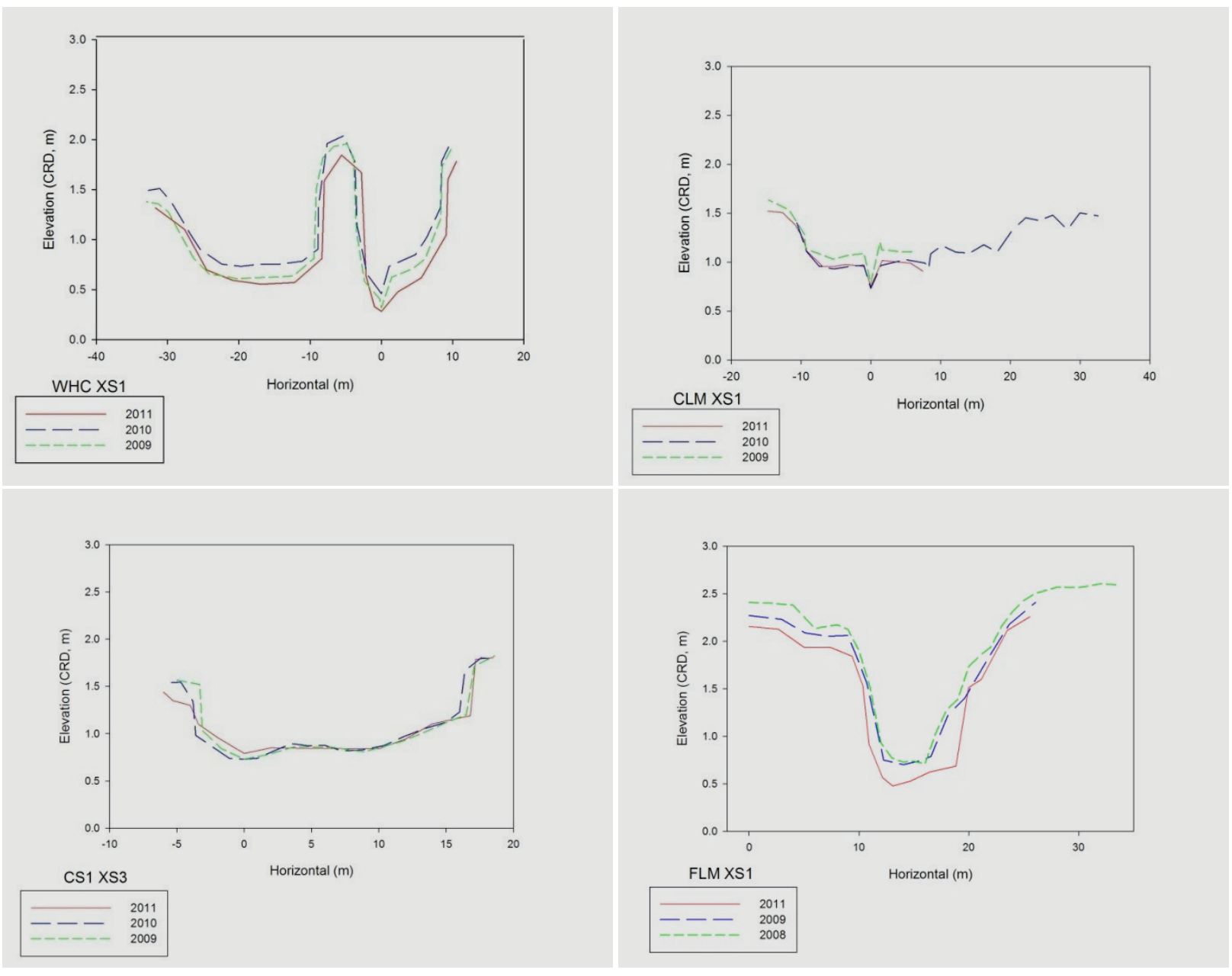

Figure 33. Elevations of the channel cross sections for the core sites showing multiple years. 


\subsection{Conclusions and Recommendations}

\subsection{Conclusions}

In this report, we begin to document the ranges and variation in hydrology and habitat structure of emergent marshes in the LCRE. Temporal and spatial variability in these systems affect the vegetation communities and their capacity for storing carbon, providing habitat for salmon, and contributing to the food web of the greater LCRE. As such, quantifying the expected ranges and variability can start to reduce uncertainties and inform research focus areas to improve the capacity of the LCRE to provide these important functions.

Spatial patterns we have been able to discern with the existing dataset fall into the primary categories contributing to wetland structure and process, specifically sediment, hydrology (elevation), and vegetation. Sediment total organic carbon (TOC) is a means of measuring the organic content in the sediments and varies over time and space depending on inundation, vegetation communities present, age of the marsh, and other sediment constituents such as grain size. Given this complexity, the factors contributing to the variability in sediment TOC at our study sites is difficult to ascertain. All samples from the study area had values less than 10 percent TOC, with the highest values in the high marsh areas, which is a pattern consistent with measurements elsewhere (Odum et al., 1984). However, the values measured can generally be considered low for tidal wetlands, with overall lower TOC at known created sites. While little data has been collected on organic content in tidal freshwater and brackish marshes in the northwest, one study in a tidal freshwater marsh in the region found TOC between 16 and 26 percent (Thom et al. 2001) while Craft (2007) has documented that tidal freshwater marsh sediments often have higher organic content than salt marshes. One study in the LCRE has documented TOC levels ranging from 13 to 30 attributing the variation to marsh age and landscape position (Elliot 2004). Studies in other areas have seen patterns of higher organic content in high marshes and lower in low marshes (Odum et al., 1984); we have noted similar but limited patterns in our data as well. While we cannot conclude the factors contributing to low TOC levels at our study sites at this time, we can hypothesize that likely a combination of vegetation type, landscape position, and marsh age may be factors contributing to the lower than expected levels. Further analysis of marsh age through evaluation of historical records will hopefully inform this theory.

Sediment grain size follows a pattern in the estuary that may be partially be explained by proximity to the main channel of the River or the main stem of a tributary. The hypothesis regarding this landscape pattern is that finer sediments would be present in more backwater settings, away from the higher flows associated with the River. Sherwood et al., (1984) found similar results, with finer sediments found in the peripheral bays as compared to the main channel. This hypothesis does not completely explain the observed patterns however. Additional factors such as elevation and history of dredge material placement may also be factors. We will continue to evaluate these patterns as more data become available.

Sediment accretion is largely dependent on the sediment load of the contributing watershed, which is variable but estimated to average approximately 10 million metric tons annually in the Columbia (Sherwood et al., 1984). However, sediment transport has changed dramatically in the estuary and has been reduced an estimated 61 percent from historic levels (Bottom et al., 2005). Altered sediment 
budgets, variable transport patterns, and historical changes due to dredging and entrapment by the reservoirs interact to create a complex sediment transport environment. Likewise, marsh sediment accretion rates fell within a narrow range in our study area, but were variable in time and space throughout the estuary. For comparison, salt marsh sediment accretion rates measured in the region fell within a similar range between 0.2 to $1.7 \mathrm{~cm} / \mathrm{yr}$ (Jefferson 1975; Thom 1992). In the Fraser Estuary, sediment deposition was most often associated with the occurrence of the spring freshet with deposits of 5 $\mathrm{cm} / \mathrm{yr}$ common (Seliskar and Gallagher 1983). Rates can be also be affected by local site factors including elevation, plant density, landscape position, and sediment type. More data on accretion rates over a longer period of record and throughout the estuary will help to expand our understanding of sedimentation and erosion patterns on multiple scales.

The hydrologic variability and the resulting inundation of the marshes varies dramatically along the estuarine gradient, with high inundation and seasonal variability in the fluvial dominated upper estuary and lower inundation and daily variability in the tidal dominated lower estuary. In the mesohaline zone (5 to $18 \mathrm{ppt} ; 0$ to $15 \mathrm{rkm}$ ) near the mouth of the estuary the vegetation cover is high, however, the number of species is limited by salinity. Few non-native species are found in this zone. In the oligohaline zone ( 0.5 to $5 \mathrm{ppt} ; \sim 16$ to $40 \mathrm{rkm}$ ), species diversity starts to increase as there becomes an overlap in the number of species that can tolerate brackish and freshwater conditions. The highest species diversity occurs in the portion of the River that is tidal freshwater, but not affected by the high seasonal inundation associated with the spring freshet ( $\sim 11$ to $135 \mathrm{rkm}$ ). In the fluvial dominated tidal freshwater zone (above $135 \mathrm{rkm}$ ) vegetation cover and species diversity appear to be variable depending on the timing and magnitude of the spring freshet.

Vegetation was also evaluated as a function of elevation and indirectly inundation, as we have shown inundation is correlated with elevation when compared in hydrologically similar portions of the LCRE. The highest species diversity occurs between the elevations of approximately $1.5 \mathrm{~m} \mathrm{CRD}$ and $2.5 \mathrm{~m} \mathrm{CRD}$, consistent with other studies that have shown increased species diversity in high versus low marshes (Elliot 2004; Leck et al., 2009). Of particular interest in this analysis is the determination of the lower elevation limit of reed canary grass (Phalaris arundinacea) throughout the estuary. This aggressive nonnative invasive species lowers species diversity and has the potential to affect the food web by reducing invertebrate prey diversity as well (Spyreas et al., 2010). As such, information regarding the limiting factors for growth and success are important to determining management actions. Elevation and inundation appear to be such limiting factors. The lower depth limit varied along the estuarine gradient; affected by salinity in the oligohaline portion of the estuary and therefore only present at higher elevations where the sediments are often fresh (Seliskar and Gallagher 1983). In the tidally dominated freshwater portion of the estuary, the lower elevation ranges from approximately $1.2 \mathrm{~m}$ to $1.6 \mathrm{~m}$ CRD. This range increases to approximately 1.4 to $1.8 \mathrm{~m} \mathrm{CRD}$ in the fluvial dominated portion of the estuary as seasonal inundation increases and likely limits the lower elevation range.

We have found that the hydrologic variability observed between years is a primary factor driving variability in vegetation cover, composition, and biomass. This interannual variability associated with varying water levels was documented in our trends analysis at the three up-river core sites (located at 145, 149 , and $221 \mathrm{rkm}$ ), however the same patterns were not as discernible at the core site located at $72 \mathrm{rkm}$. The boundaries between the major species at the core sites were generally stable over time even with varying water levels. In the highest water year we did observe an increase in the lower elevation of all species at CLM, the lowest elevation site, indicating the potential for an effect on the elevation ranges 
from this level of hydrological variability. The implications of this kind of change include a potential loss of wetland area and a reduction in biomass production (discussed below).

Another trend we observed in this analysis was the interannual variability of $P$. arundinacea cover due to varying water levels; however, reductions were not persistent between years. At the lower-river core site (WHC), where interannual hydrologic variability does not appear to be a primary controlling factor, the trend over three years has been a gradual increase in cover of $P$. arundinacea and a decrease in the cover of all other species. This trend could be attributed to the invasive nature of the species or could be due to interannual variability; additional data will provide a better understanding. The slight increase in the number of species over time was likely caused by an increase in the number of quadrats each year in an attempt to adequately represent the diverse site.

Preliminary data on primary productivity and biomass export show similar results to other estuarine areas in the region for the lower estuary (i.e., sites BBM and WHC) however, the upper estuary sites (i.e., CS1 and FLM) had low values compared to other studies (Berg et al., 1980; Seliskar and Gallagher 1983; Small et al., 1990; Thom et al., 2001). Although high variability in both salt marshes and tidal freshwater marshes make comparisons difficult (Odom 1988), the low values observed in the upper estuary are likely due to the effects of the high water in 2011. Because the interannual variability in water level and position in the estuary affect the timing of peak biomass, we need to evaluate these differences and potentially modify future sampling efforts.

Inundation of the marsh channel mouths varies longitudinally and as expected between sites with varying channel elevations and morphologies. This affects the potential for fish access and is important for understanding the contribution of these marshes for refuge, feeding, and cover. Most channels were accessible for at least 60 percent of the time and most channel banks accessible for at least 40 percent of the estimated peak juvenile salmonid migration period. These elevations can be useful for informing restoration projects to ensure that salmon access is maximized at the site.

In general, the emergent marshes of the LCRE that were evaluated in this study are diverse, productive systems with channels that are providing the opportunity for juvenile salmonids access throughout the LCRE. Additional research evaluating the capacity differences between these emergent wetlands will further reduce the uncertainties regarding the quality of these systems for juvenile salmon. Further research on TOC in the sediment, biomass export, site history, sedimentation rates, and nonnative species will help to better understand other ecosystem processes and functions such succession, carbon storage, and food web support 


\subsection{Recommendations}

\section{Sedimentation and Elevation}

Surface elevation tables (SET) could be installed at some or all of the core monitoring locations to evaluate accuracy of the current method for measuring wetland accretion or erosion and to allow for better characterization of overall elevation changes due to sediment dynamics and shallow subsidence (Rybczyk and Cahoon 2003). In addition, multiple sediment accretion stakes could be placed at core sites to look at site-scale patterns of sediment dynamics.

\section{$\underline{\text { Hydrology }}$}

Timing of sensor deployment should be changed so the entire growing season is recorded in one year (e.g., deploy and retrieve in late October).

\section{$\underline{\text { Vegetation }}$}

In future years, the mapping effort could be reduced at core sites unless obvious change is observed; maybe every 3-5 years. More time should be focused on the biomass collection effort to ensure we are getting representative results and to better our understanding of the variability associated with this metric. As such, additional seasonal sampling may be needed to further evaluate cover and biomass changes throughout the year and the addition of more biomass samples would reduce the variability we are seeing within sites, especially in the SAV zone.

\section{Channel Morphology}

In future years, single cross sections at the channel mouth could probably be measured at the core sites to evaluate change, with the whole channel being surveyed less frequently. Changes in the channel morphology would likely be detected by measurements at the channel mouth. If change was observed at the mouth then a full survey should be completed in the following year. Otherwise, the channel could be surveyed at a regular interval such as every 5 years. In addition, at core sites the channel cross sections need to be surveyed at exactly the same start points and at consistent intervals to be able to evaluate change over time. Initial surveys of the rotating sites should still have the full channel surveyed as part of the characterization of the site. 


\subsection{References}

Araya, Y.N., J. Silvertown, D.J. Gowing, K.J. McConway, H.P. Linder and G. Midgley. 2010. A fundamental, eco-hydrological basis for niche segregation in plant communities. New Phytologist (2010): 1-6.

Bottom, D.L., C.A. Simenstad, J. Burke, A.M. Baptista, D.A. Jay, K.K. Jones, E. Casillas, and M.H. Schiewe. 2005. Salmon at river's end: the role of the estuary in the decline and recovery of Columbia River salmon. U.S. Dept. Commer., NOAA Tech. Memo. NMFS-NWFSC-68, 246 p.

Borde, AB, VI Cullinan, HL Diefenderfer, RM Thom, RM Kaufmann, J Sagar, and C Corbett. 2012. Lower Columbia River and Estuary Ecosystem Restoration Program Reference Site Study: 2011 Restoration Analysis. Prepared for the Lower Columbia River Estuary Partnership by Pacific Northwest National Lab

Borde, AB, SA Zimmerman, RM Kaufmann, HL Diefenderfer, NK Sather, and RM Thom. 2011a. Lower Columbia River and Estuary Restoration Reference Site Study: 2010 Final Report and Site Summaries. PNWD-4262, prepared for the Lower Columbia River Estuary Partnership by the Battelle Marine Sciences Laboratory, Sequim, Washington.

Borde, AB, SA Zimmerman, RM Kaufmann, RM Thom, VI Cullinan, and NK Sather. 2011b. Lower Columbia River and Estuary Habitat Monitoring 2010 Annual Report. PNWD-4233. Prepared for the Lower Columbia River Estuary Partnership by the Battelle Marine Sciences Laboratory, Sequim, Washington.

Burg, ME, DR Tripp, ES Rosenberg. 1980. Plant associations and primary productivity of the Nisqually salt marsh on Southern Puget Sound, Washington. Northwest Science 54:222-236.

Clark, KR and RM Warwick. 2001. Change in marine communities: an approach to statistical analysis and interpretation, $2^{\text {nd }}$ edition. PRIMER-E Ltd. Plymouth, UK.

Craft, C.B. 2007. Freshwater input structures soil properties, vertical accretion, and nutrient accumulation of Georgia and U.S. tidal marshes. Limnol.Oceanogr. 52:1220-1230.

Dauphinee, TM. 1980. Introduction to the special issue on the Practical Salinity Scale 1978. IEEE J. of Oceanic Eng., Vol. OE5, p. 1-2.

Diefenderfer, H.L., A.M. Coleman, A.B. Borde, and I.A. Sinks. 2008. Hydraulic geometry and microtopography of tidal freshwater forested wetlands and implications for restoration, Columbia River, U.S.A. Ecohydrology and Hydrobiology 8:339-361.

Diefenderfer, H.L. and D.R. Montgomery. 2009. Pool spacing, channel morphology, and the restoration of tidal forested wetlands of the Columbia River, U.S.A. Restoration Ecology 17:158-168. 
Elliot, CM. 2004. Environmental and historical factors driving vegetation communities on Russian Island, Columbia River Estuary. Master of Science Thesis, University of Washington, Seattle, Washington.

Fresh, K. personal communication with Nichole Sather on 8/25/2011.

Gowing, D.G., CS Lawson, EG Youngs, KR Barber, JS Rodwell, MV Prosser, HL Wallace, JO Mountford, and G Spoor. 2002. The water regime requirements and the response to hydrological change of grassland plant communities. Project BD1310 for the Department of Environment, Food, and Rural Affairs by Institute of Water and Environment, Bedford, UK.

Hensel, PE, JW Day Jr. and D Pont. 1999. Wetland Vertical Accretion and Soil Elevation Change in the Rhône River Delta, France: The Importance of Riverine Flooding. Journal of Coastal Research 15(3):668-681.

Hoffnagle, JR. 1980. Estimates of vascular plant primary productivity in a west coast salt marsh-estuary ecosystem. Northwest Science 54:68-78.

Jay, DA, K Leffler, HL Diefenderfer, and AB Borde. In review 2011. Tidal-fluvial and estuarine processes in the Lower Columbia River: I. Along-channel water level variations, Pacific Ocean to Bonneville Dam. Estuaries and Coasts.

Jefferson, CA. 1975. Plant communities and succession in Oregon coastal salt marshes. PhD dissertation, Oregon State University, Corvallis, Oregon.

Johnson GE, HL Diefenderfer, RM Thom, GC Roegner, BD Ebberts, JR Skalski, AB Borde, EM Dawley, AM Coleman, DL Woodruff, SA Breithaupt, AS Cameron, CA Corbett, EE Donley, DA Jay, Y $\mathrm{Ke}, \mathrm{KE}$ Leffler, CB McNeil, CA Studebaker, and JD Tagestad. 2011. Evaluation of Cumulative Ecosystem Response to Restoration Projects in the Lower Columbia River and Estuary, Annual Report 2010. PNNL-20296, prepared for the U.S. Army Corps of Engineers, Portland District, Portland, Oregon, by Pacific Northwest National Laboratory, Richland, Washington.

Johnson, GE, NK Sather, AJ Storch, DJ Teel, JR Skalski, EM Dawley, AJ Bryson, GR Ploskey, C Mallette, TA Jones, AB Borde, SA Zimmerman, ES Van Dyke, DR Kuligowski, and KL Sobocinski. 2011. Ecology of Juvenile Salmon in Shallow Tidal Freshwater Habitats of the Lower Columbia River, 2007-2010. PNNL-20083, Pacific Northwest National Laboratory, Richland, Washinton.

Kentula, M, R Brooks, S Gwin, C Holland, A Sherman, and J Sifneos. 1992. An approach to improving decision making in wetland restoration and creation. EPA/600/R-92/150. USEPA, Washington, D.C.

Leck, MA, AH Baldwin, VT Parker, L Schile, and DF Whigham. 2009. Plant communities of tidal freshwater wetlands of the continental USA and southeastern Canada. In: Barendregt, A, D Whigham, and A Baldwin (eds). 2009. Tidal Freshwater Wetlands. Backhuys Publishers, Leiden, The Netherlands. 
Macdonald, K.B. 1984. Tidal Marsh Plant Production in the Columbia River Estuary. Prepared for the Columbia River Estuary Data Development Program and the Columbia River Estuary Study Task Force, Astoria, Oregon.

Mitsch WJ and JG Gosselink. 2000. Wetlands. 3rd ed., John Wiley \& Sons, Inc., New York.

Natural Resource Conservation Service (NRCS). 2002. Wetland determination (WETS) table for Clark County,WA. Available at: ftp://ftp.wcc.nrcs.usda.gov/support/climate/wetlands/or/41007.txt

Odum, WE, TJ Smith III, JK Hoover, and CC McIvor. 1984. The ecology of tidal frewhwater marshes of the United States east coast: a community profile. US Fish Wildlife Service. FWS/OBS-83/17. $177 \mathrm{pp}$.

Odum, WE. 1988. Comparative ecology of tidal freshwater and salt marshes. Ann. Rev. Ecol. Syst. 19:147-76.

PSEP. 1986. Puget Sound Estuary Program: Recommended protocols for measuring conventional sediment variables in Puget Sound. Final report. Prepared for U.S. Environmental Protection Agency, Region 10, Office of Puget Sound, Seattle, WA and the U.S. Army Corps of Engineers, Seattle District, Seattle, WA. Tetra Tech, Inc., Bellevue, WA.

Roegner, GC, HL Diefenderfer, AB Borde, RM Thom, EM Dawley, AH Whiting, SA Zimmerman, GE Johnson. 2009. Protocols for monitoring habitat restoration projects in the lower Columbia River and estuary. US Dept. Commerce, NOAA Tech Memo. NMFS-NSFSC-97, 63p.

Rybczyk JM, Cahoon DR (2002) Estimating the potential for submergence for two subsiding wetlands in the Mississippi river delta. Estuaries 25:985-998

Sather, NK, DJ Teal, AJ Storch, GE Johnson, ES Van Dyke, EM Dawley, DR Kuligowski, TA Jones, AJ Bryson, and KL Sobocinski. 2011. "Juvenile Salmon and Fish Community Characteristics." In: Ecology of Juvenile Salmon in Shallow Tidal Freshwater Habitats of the Lower Columbia River, 2007-2010. Johnson et al., pp. 2.1-4.35, PNNL-20083, Pacific Northwest National Laboratory, Richland, Washington.

Seliskar, DM and JL Gallagher. 1983. The Ecology of Tidal Marshes of the Pacific Northwest Coast: A Community Profile. US Fish and Wildlife Service, Division of Biological Services, Washington DC. FWS/OBS-82/32. 65 pp.

Sherwood, CR, JS Creager, EH Roy, G Gelfenbaum, T Dempsey. 1984. Sedimentary Processes and Environments in the Columbia River Estuary. Prepared for the Columbia River Estuary Data Development Program and the Columbia River Estuary Task Force, Astoria, Oregon.

Simon, S.D., M.E. Cardona, B.W. Wilm, J.A. Miner, and D.T. Shaw. 1997. "The sum Exceedance value as a measure of wetland vegetation hydrologic tolerance." In: Macdonald, K.B. and F. Weinmann (eds). 1997. Wetland and Riparian Restoration: Taking a Broader View. Proceedings of Society for Ecological Restoration, 1995 International Conference, September 14-16, University of Washington, USA. Publication EPA 910-R-97-007, USEPA, Region 10, Seatte, Washington. 
Simenstad, CA and JR Cordell, Ecological assessment criteria for restoring anadromous salmonid habitat in Pacific Northwest estuaries, Ecological Engineering 15(3-4):283-302.

Small, LF, CD McIntire, KB Macdonald, JR Lara-Lara, BE Frey, MC Amspoker and T Winfield. 1990 Primary production, plant and detrital biomass, and particle transport in the Columbia River estuary. Progress in Oceanography 25:175-210.

Spyreas, G, BW Wilm, AE Plocher, DM Ketzner, JW Matthews, JL Ellis, EJ Heske. 2010. Biological consequences of invasion by reed canary grass (Phalaris arundinacea). Biological Invasions 12:1253-1267.

Thom, RM. 1992. Accretion rates of low intertidal salt marshes in the Pacific Northwest. Wetlands 12(3):147-156.

Thom, RM, SL Blanton, DL Woodruff, GD Williams, and AB Borde. 2001. Carbon Sinks in Nearshore Marine Vegetated Ecosystems. In: Proceedings of the First National Conference on Carbon Sequestration, 14 - 17 May, The National Energy Technology Laboratory (NETL). Available at www.netl.doe.gov/publications/proceedings/01/carbon_seq/5c5.pdf 


\section{Appendix A - Ecosystem Monitoring Reconnaissance Trip Report}

Reproduction of a memorandum originally submitted to the LCREP on 11/22/2010 



\section{Ecosystem Monitoring Reconnaissance Trip \\ November 17-18, 2010}

Objectives:

1. Conduct site visits in Reaches D, E, and F to determine feasibility of sampling fish and adequacy of sites to meeting project criteria (i.e., relatively undisturbed, emergent marsh, of adequate size and connectivity to the Col. River, with sloughs or channels present and potential for fish access) with intent to choose 3 rotating sites for 2011.

2. Conduct site visits in Reach A to determine feasibility and potential for meeting site criteria with intent to choose one fixed site for long term monitoring.

\section{Original Site List:}

\section{$\underline{\text { Rotating Sites }}$}

Reach D

- Dibblee Slough; sampled for vegetation in 2005 (technically now in Reach C due to changes in Classification)

- 2 sites on Cottonwood Is; sampled for vegetation in 2005; sampled for fish under Salmon Benefits and NMFS in 2010, 2011

- North of Prescott-across from Cottonwood Island; might have road access

Reach E

- Lewis River confluence (dredge material islands); sampled for vegetation in 2007

- Martin Island (cattle impacts?); sampled for vegetation in 2007

- Sandy Island; sampled for vegetation and fish/fish prey in 2007

- Goat Island (dredge material placement)

- Deer Island on upstream side of Goat Island

Reach F

- Inside Willow Bar

- Cunningham Lake (might be inaccessible for seining)

- West side of Sauvie Island

- Backside of Scappoose Landings

- West Hayden Island

Fixed site in Reach A

- Inside of Clatsop Spit

- Inside lee side of West Sand Island

- Just west of Ilwaco Marina

- Wallacut Creek confluence

- Chinook River confluence 


\section{Day One - November 17 - Rotating Site Selection}

Amy Borde, PNNL

Sean Sol and Paul Olson, NOAA

Keith Marco, LCREP

0800 Reach D. Launched at Rainier to visit Reach D sites. We prioritized the site visit to include

Cottonwood Is. and Prescott slough, but not Dibblee slough due to time constraints and the fact that it is in Reach C.

\section{Cottonwood Island}

Observations: Both sites were deemed acceptable by all parties, with the larger slough site being preferable for fish sampling due to the size. Both sites would have to be accessed at high water for fish sampling.

Other information: Vegetation has been previously sampled by PNNL as part of this study in 2005 and for the Reference Site Study (RSS) in 2010. Fish sampling (monthly beach seining) has occurred at both sites in 2010 as part of the Salmon Benefits project. Water properties sampling (TSS, nutrients, chlorophyll) has also occurred at or near the sites as part of the SB project. The NOAA Fish Ecology (FE) group has also been conducting fish sampling at the downstream end of Cottonwood Island near the confluence of the Cowlitz and Columbia. To our knowledge no prey, diet, or contaminant research has been conducted in any of these studies, but this should be checked. A PNNL depth sensor is located in the big slough (since March 2009).

\section{$\underline{\text { Prescott Slough }}$}

Observations: The site was accessed by foot due to low water. The site has a narrow channel at the entrance leading back to an open, shallow wetland that grades up to $P$. arundinacea (reed canary grass, willows, and cottonwoods). The channel continues up past the site, under the railroad trestle to a tide gated diked area where the old Trojan nuclear reactor was built but never activated. The site was seen as feasible for fish sampling at high water.

Other Information: No previous sampling is known to have occurred at this site. Ownership is unknown at this time. Access is possible from the Prescott Beach County Park located near the site either by walking along the shoreline at low water or by walking through the trees. PNNL installed a water level sensor and sediment accretion stakes at the site (on 11/19/10) in the event the site is selected as a monitoring site.

1100 Reach E. Launched at St. Helens to visit Reach E sites. We prioritized the site visit to focus on Deer Is., Goat Island, and Burke Island (a late addition based on a recommendation from a PNNL colleague). We did not visit the site near the confluence of the Lewis River due to small size of the site and the lack of any real off channel habitat. We boated past Martin Island to confirm that the site also had only a small fringing wetland with no channel habitat and cows were present at the site. Sandy Island had been sampled by all parties in 2007 and therefore a site visit was not necessary. 


\section{Deer Island/Goat Island}

Observations: The sloughs at the upstream end of Deer Island were accessed by boat to the pile structure running along the upstream end of Goat/Deer Island. We walked over to the slough on Deer island. The water levels were up to the higher marsh, so lower vegetation areas could not be observed, but based on the aerial imagery and the shape of the slough, it is assumed that an area of low marsh also exists at the site. The site was deemed fish-able. We could see a portion of the wetland slough on Goat Island from our location on Deer Island and based on the imagery and previous site visits by PNNL the site was also deemed acceptable by all. Fish sampling would need to be conducted at high water.

Other information: Ownership of Goat Island in known to be private. Ownership of Deer Island needs to be determined. PNNL has sampled vegetation in 2009 as part of the Cumulative Effects (CE) project and RSS. Limited fish sampling was conducted in this year by NOAA-FE (Curtis Roegner).

\section{Burke Island}

Observations: We accessed the site by boat at high water. There is a small channel outlet at the mouth of the slough bordered by shrubs and trees. Just past this border, the site opens up into a shallow slough bordered by low and high marsh grading up to pasture on one side and trees on the other side. The pasture was separated from the wetland by a barbed wire fence. No cows were seen in the area and no sign of grazing was observed in the wetland area. Due to the high water the lower elevations of the site could not be observed, however similar to Deer Island the site likely meets the criteria for vegetation sampling. The site was seen as feasible for fish sampling at high water.

Other information: Ownership of the site needs to be determined; it appeared to be private property due to presence of a duck blind and no trespassing signs. The site can only be accessed by boat.

$\underline{\text { Reach F }}$ - Due to time constraints and weather, we decided not to visit the Reach F sites.

\section{Day Two - November 18 - Fixed Site Selection in Reach A}

Amy Borde, PNNL

Sean Sol and Paul Olson, NOAA

Keith Marco, LCREP

Whitney Temple and Dave Piatt, USGS

Due to time and access constraints we decided not to visit the Wallacut Creek site, a low priority due to the apparent lack of tidal channels from the imagery.

0900 High Tide. We observed the Chinook River mouth site from across the Chinook River to get an idea of the extent of inundation relative to the vegetation and the channels. We then launched the boat from the Ilwaco marina and visited the site just west of the marina and on west Sand Island. The Sand Island site was rejected due to the lack of channel habitat. The marina site and the Chinook site were deemed worthy of a second visit at lower water later in the day. 
1300 Mid Tide. We drove to the Clatsop Spit/Trestle Bay site and walked out to the marshes located just outside the old trestle/dike. The marshes were well vegetated, however the tidal channels were very small and did not meet the site criteria.

1500 Low Tide. We returned to the two sites that seemed most viable: Chinook and the Marina site for evaluation at low tide.

\section{Chinook River Mouth}

Observations: We walked into this site at low water via an old road off Hwy 4. This site has a diverse mix of vegetation from low elevation marsh gradually sloping up to high marsh with driftwood along the upper margin. The channel was deep (approx. $4 \mathrm{ft}$ ) and 10 to $15 \mathrm{ft}$ wide with vegetation on the banks and submerged vegetation in the channel. Wood was observed in the banks and on the bottom of the channel, indicating 1) the area is and/or has been a repository for large wood and 2) the marsh has been around long enough to accrete considerable amounts of sediment over the wood noted in the banks of the channel. The channel appeared to have some deep pools that might allow for deployment of USGS sensors; evaluation at a lower water level would be needed. It was determined that the site would be difficult to sample logistically due to the location and the wood in the channel, however it seemed to be the least disturbed of all the sites we looked at and to have the most developed marsh and tidal channel making it worth the effort to figure out the sampling challenges.

Other information: The site is in private ownership and long-term access to the site would need to be determined. PNNL sampled the vegetation, elevation, and water level at this site in 2009. CREST has sampled for fish sometime prior to that. The site was present on the historic maps of the late 1800's unlike any of the other marshes on our site selection list or possibly in all of Reach A. This site is a unique example of a diverse, mature, and stable marsh that was likely common in the historic floodplain of the estuary. This site would be the first choice of the EM team if access/ownership is resolved.

\section{$\underline{\text { Ilwaco Marina Marsh }}$}

Observations: We were able to walk into the site via the western jetty of the marina (Sean Sol gained permission from the business located on the jetty). The channel was shallower and wider than the Chinook site with no observable wood in the channel or on the marsh. The site would be accessible for fish sampling and the channel could possibly be deep enough for the USGS sensor at low tide. The vegetation was a mix of low marsh species (as much as could be discerned from the remnant fall vegetation). There did not appear to be a higher marsh, as the low marsh abuted the steep bank/bluff at the margin of the site.

Other information: Ownership of the site appears to be the State and the Port based on the Pacific County Assessors website. The marsh was not present on the historic maps and seems likely to have formed in the years since due to sedimentation from changes in circulation in Baker Bay and possibly from the jetty/marina located nearby. This would explain the shallow channel and the presence of only low marsh.

While at the site, PNNL installed a water level sensor and sediment accretion stakes. This was done because ownership was not a concern and to gain preliminary information in the event the site is chosen for monitoring. 


\section{Summary}

Priorities based on site feasibility (not ownership or other research):

Potential Reach D sites

- Cottonwood Island big slough and Prescott slough

- Cottonwood Island small slough

Potential Reach E sites

- All sites equal: Deer Island, Goat Island, Burke Island, Sandy Island

Potential Reach A fixed site

- Chinook

- Ilwaco 

Appendix B-Site Maps 



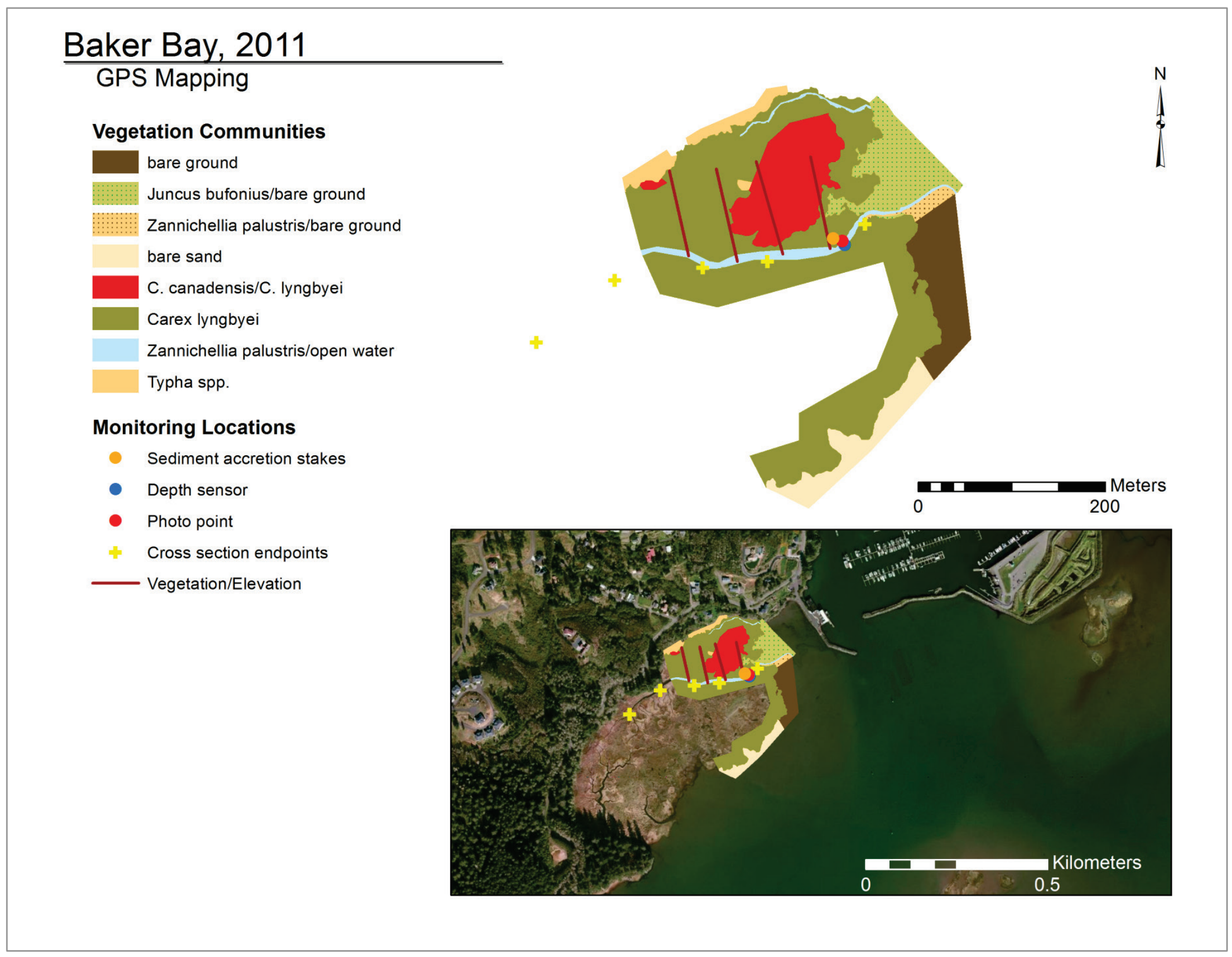




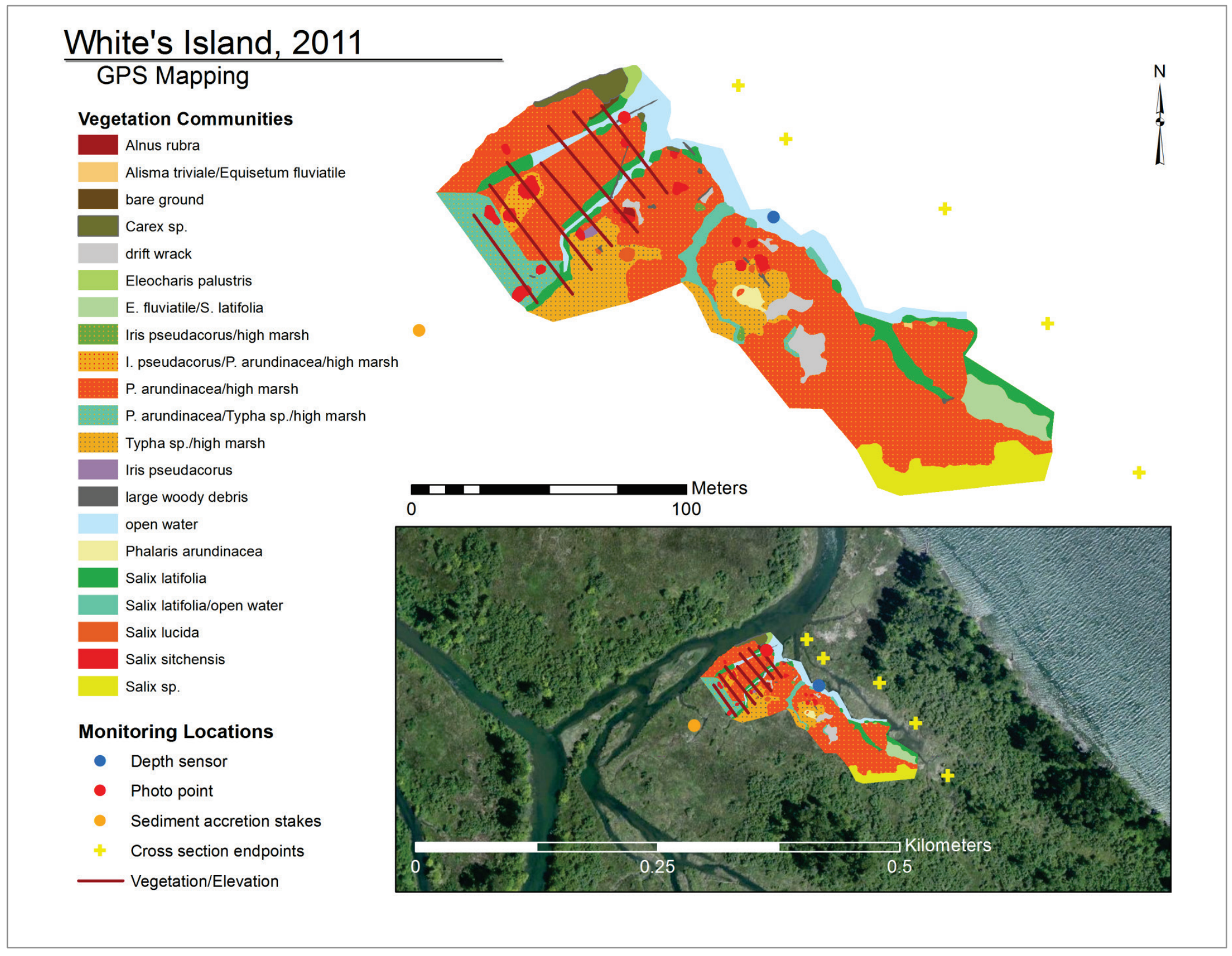




\section{Burke Island, 2011}

GPS Mapping

\section{Vegetation Communities}

bare ground

Carex obnupta

C. obnupta/sparse S. latifolia

Eleocharis palustris

E. palustris/P. arundinacea

E. palustris/P. arundinacea/S. latifolia

E. palustris/S. latifolia

open water

Phalaris arundinacea

Sagittaria latifolia

S. latifolia/P. arundinacea

Salix lucida

S. lucida/ P. arundinacea

\section{Monitoring Locations}

- Depth sensor

- Sediment accretion stakes

* Cross section endpoints

Vegetation/Elevation
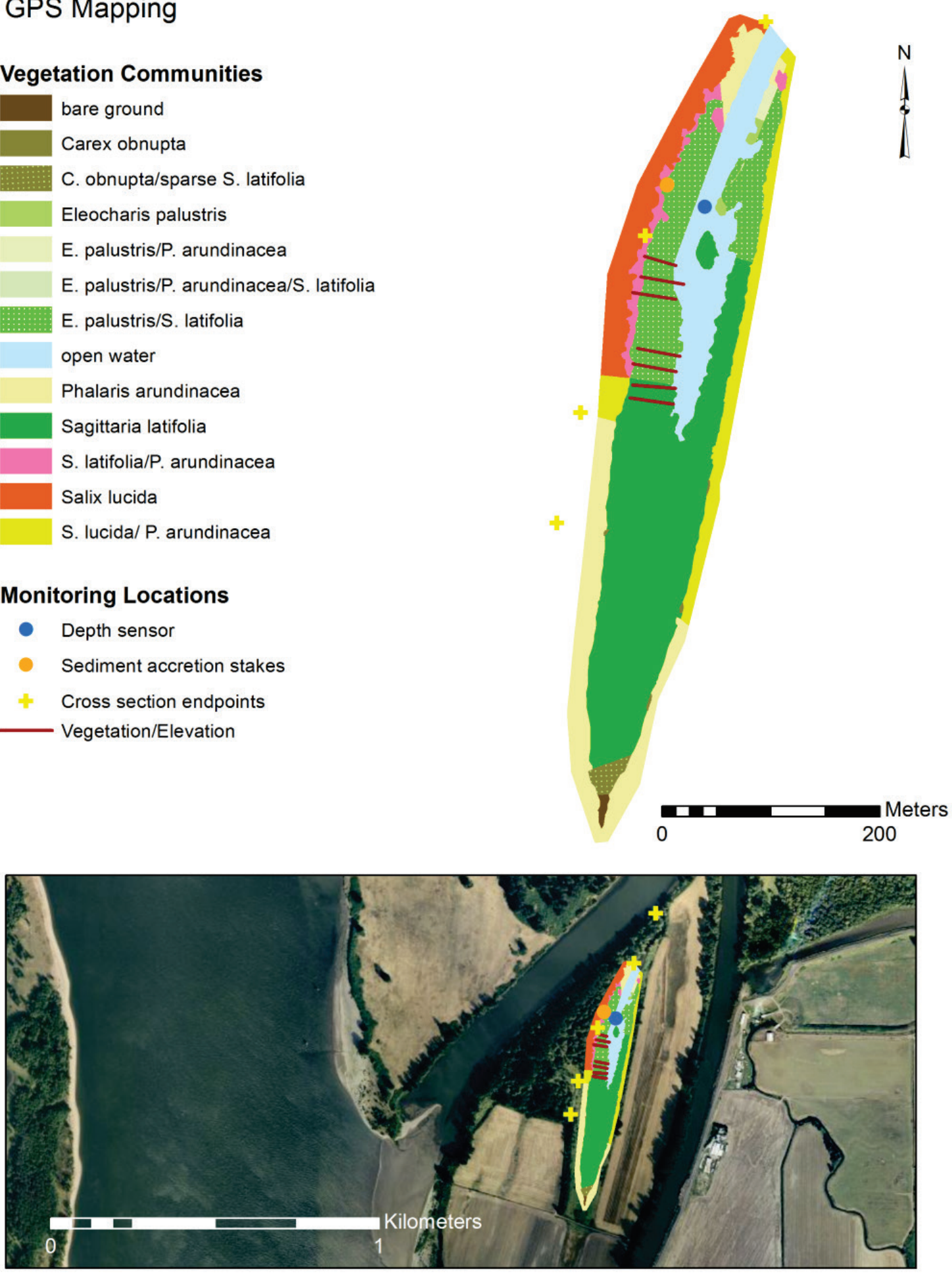



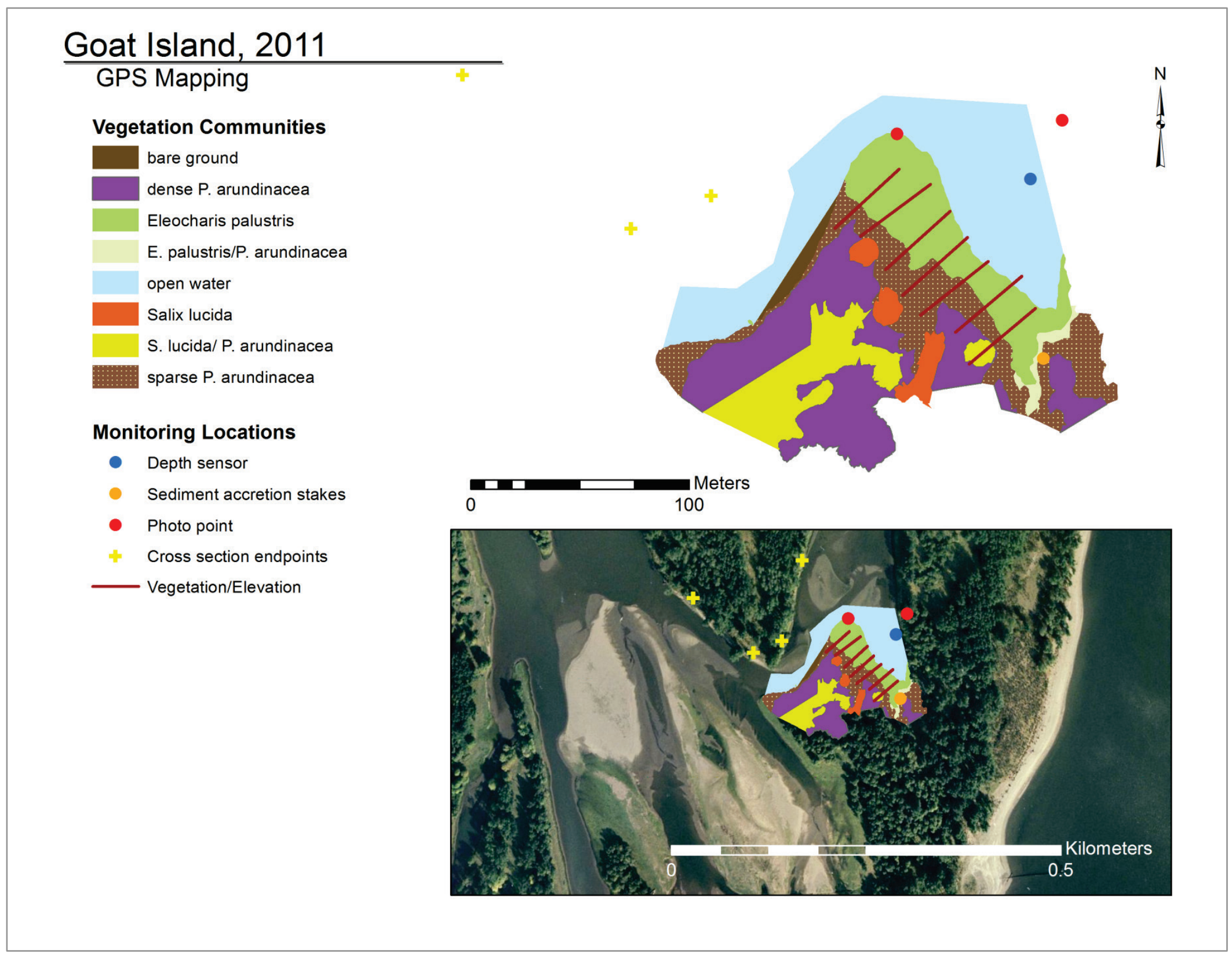




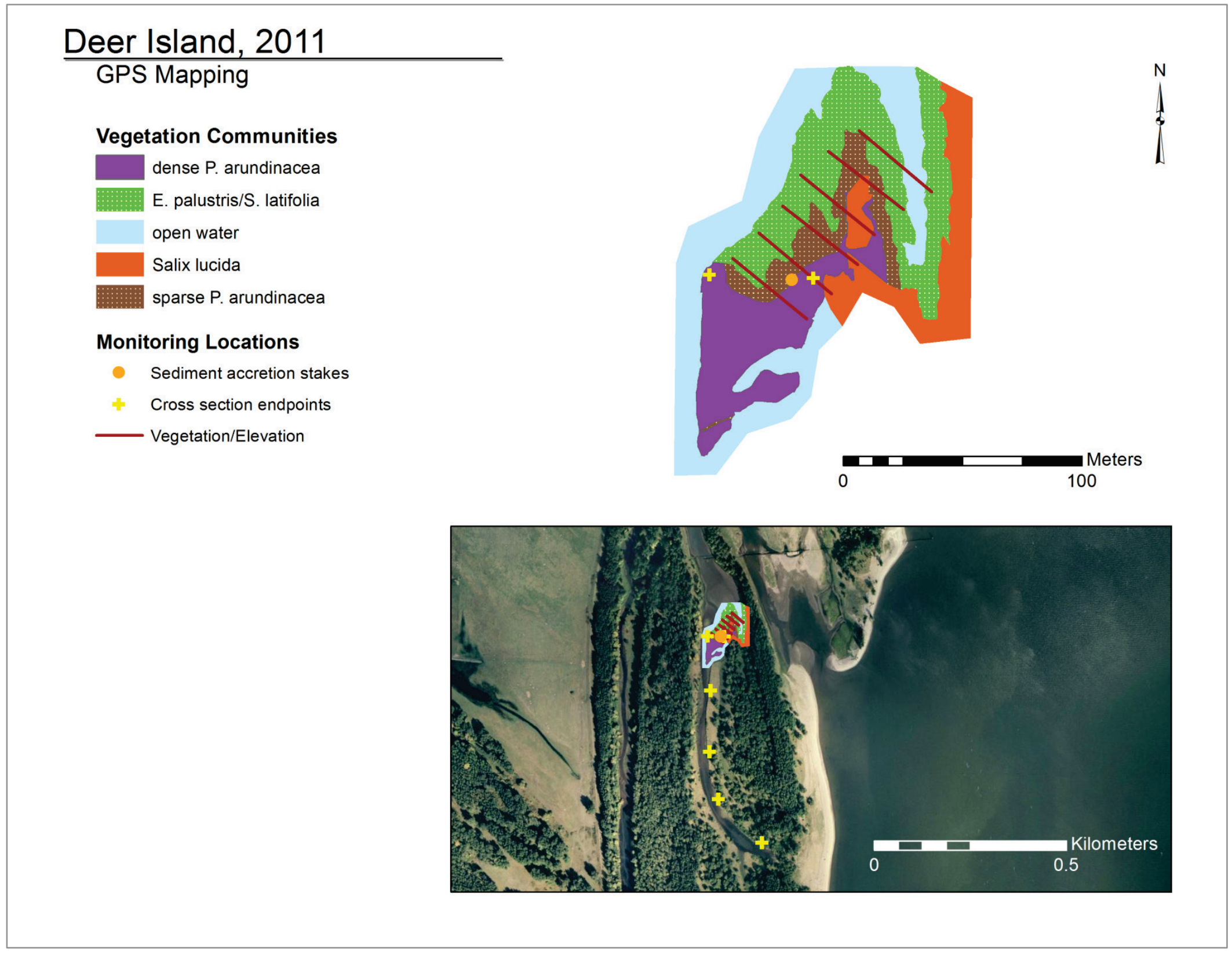




\section{Cunningham Lake, 2011}

\section{GPS Mapping}

Vegetation Communities

dense P. arundinacea

open water

E. palustris/P. arundinacea/open water

S. latifolia/P. arundinacea

Salix lucida

\section{Monitoring Locations}

- Sediment accretion stakes

- Depth sensor

- Photo point

* Cross section endpoints

- Vegetation/Elevation

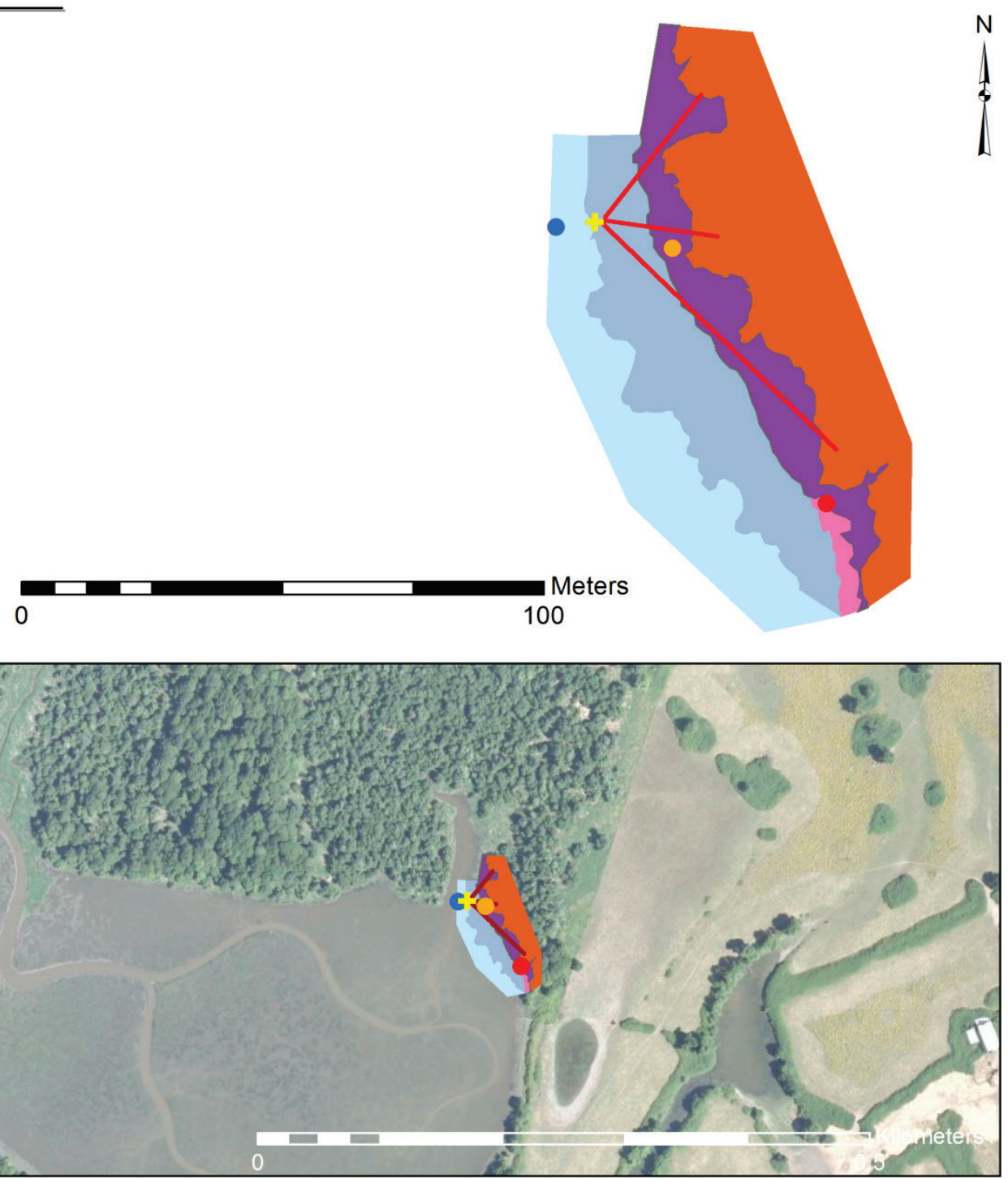




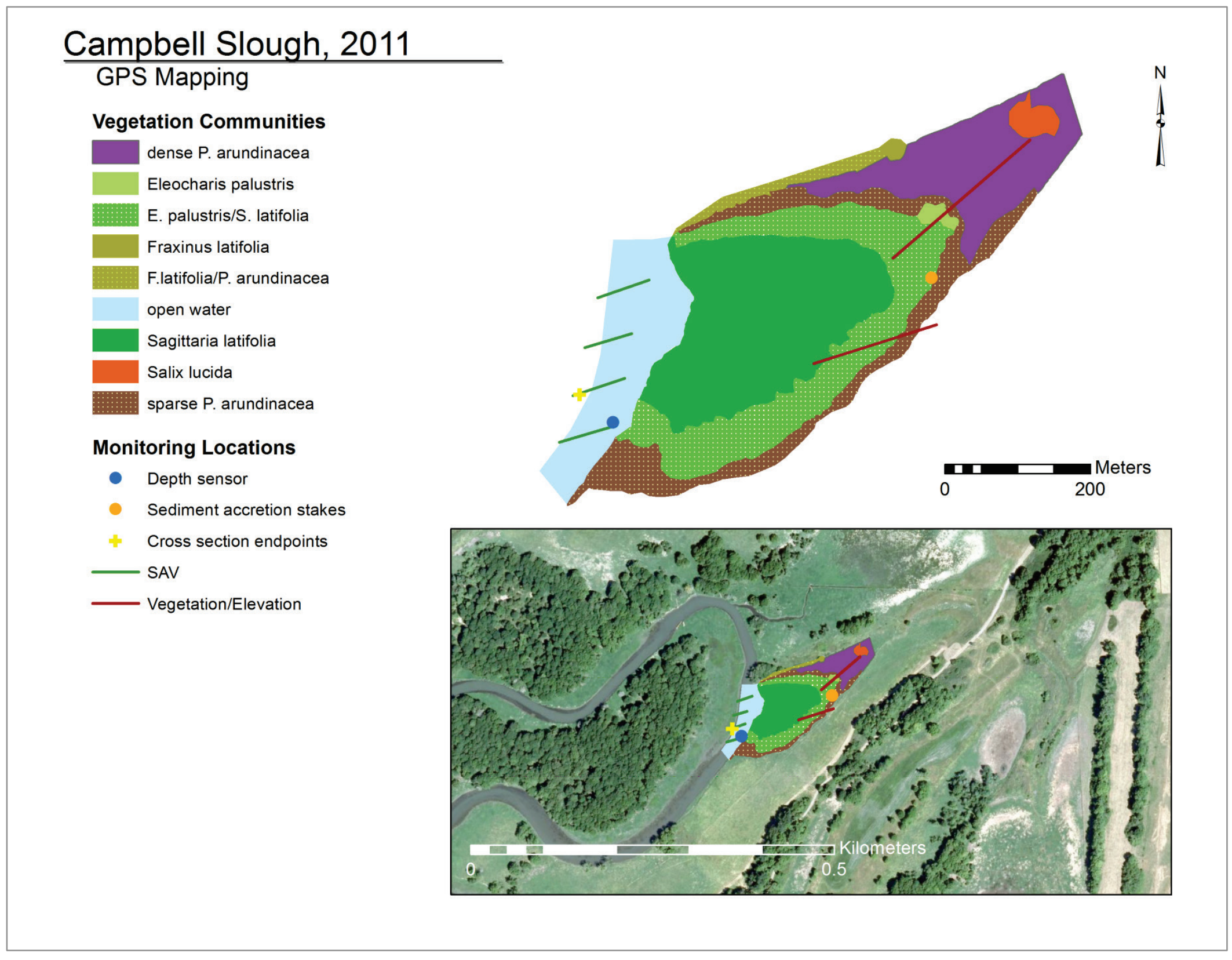


Franz Lake, 2011

\section{GPS Mapping}

Vegetation Communities

Amorpha fruticosa

VIIA beaver run

Carex sp.

dead Eleocharis palustris

dead $P$. arundinacea/P. amphibium

Eleocharis palustris

E. palustris/P. amphibium

E. palustris/P. amphibium/S. latifolia

E. palustris/S. latifolia

Fraxinus latifolia/Salix lucida

large woody debris

open water

Phalaris arundinacea

P. arundinacea/P. amphibium

P. arundinacea/P. amphibium/open water

P. arundinacea/S. lucida saplings

Polygonum amphibium

Polygonum amphibium/open water

P. amphibium/S. latifolia

rock

Sagittaria latifolia

Salix lucida

Salix lucida saplings Salix sitchensis saplings sparse Eleocharis palustris

sparse Phalaris arundinacea

Monitoring Locations

- Depth sensor

- Sediment accretion stakes

* Cross section endpoints

sparse Sagittaria latifolia

- Vegetation/Elevation

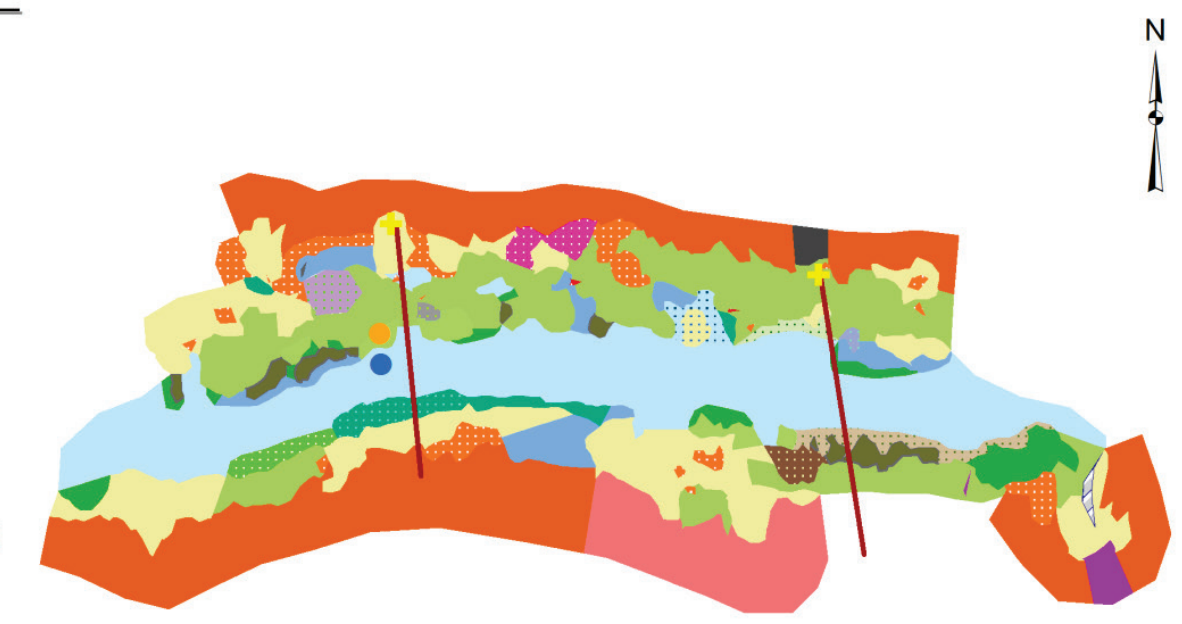

0 Meters

100

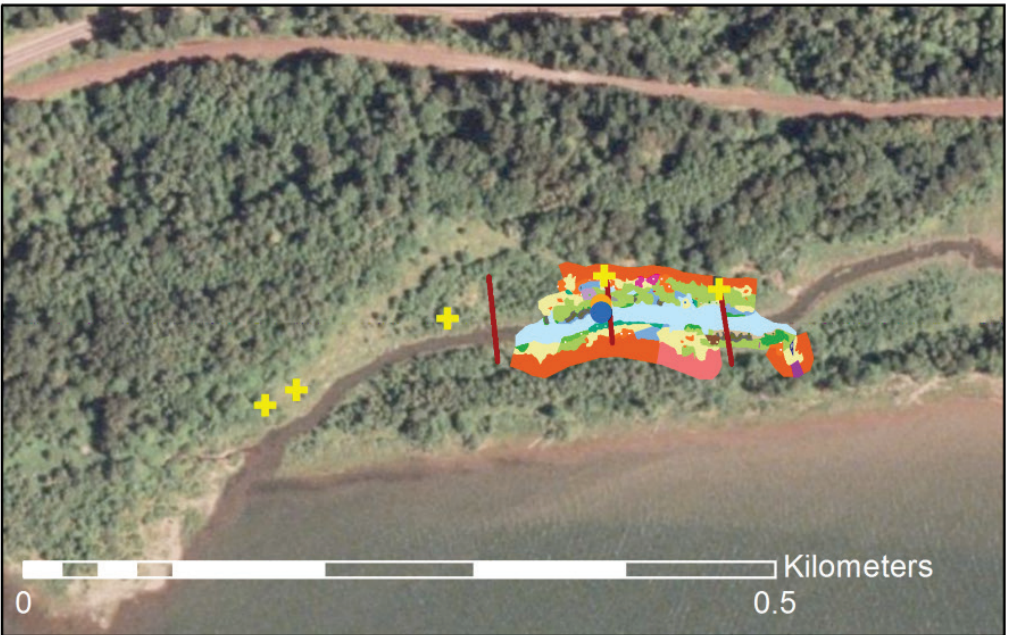





\section{Appendix C-Vegetation Species Cover}



Table A1. Site elevation (in meters, relative to the Columbia River vertical datum CRD) and vegetation species average percent cover. The three dominant cover classes are bolded in red for each site and the invasive species are shaded in yellow (not necessarily non-native species). Species are sorted by their four letter code ( $1^{\text {st }}$ two letters of genus and $1^{\text {st }}$ two letters of species).

\begin{tabular}{|c|c|c|c|c|c|c|c|c|c|c|c|c|}
\hline Code & Scientific Name & Common Name & Wetland Status & Native & BBM & BIM & CLM & CS1 & DIC & FLM & GIC & WHC \\
\hline \multirow[b]{5}{*}{ Code } & \multirow[b]{5}{*}{ Scientific Name } & \multirow[b]{5}{*}{ Common Name } & \multirow[b]{5}{*}{ Wetland Status } & & \multicolumn{8}{|c|}{ Elevation (m, CRD) } \\
\hline & & & & Min & 0.97 & 0.97 & 1.02 & 1.16 & 0.85 & 0.968 & 1.09 & 1.66 \\
\hline & & & & Avg & 2.00 & 1.18 & 1.37 & 1.66 & 1.51 & 1.851 & 1.57 & 1.95 \\
\hline & & & & Max & 2.39 & 1.56 & 1.68 & 2.69 & 2.60 & 2.333 & 2.13 & 2.24 \\
\hline & & & & Native & \multicolumn{8}{|c|}{ Average Percent Cover } \\
\hline AGST & Agrostis stolonifera L. & $\begin{array}{l}\text { creeping } \\
\text { bentgrass }\end{array}$ & FAC & no & 0.00 & 0.00 & 0.00 & 0.00 & 0.00 & 0.00 & 0.00 & 0.62 \\
\hline ALTR & Alisma triviale & $\begin{array}{l}\text { northern water } \\
\text { plaintain }\end{array}$ & $\mathrm{OBL}$ & yes & 0.00 & 0.00 & 0.00 & 0.00 & 0.07 & 0.00 & 0.00 & 0.62 \\
\hline CAAM & Castilleja ambigua & $\begin{array}{l}\text { paint-brush owl- } \\
\text { clover; johnny- } \\
\text { nip }\end{array}$ & $\mathrm{FACW}+$ & yes & 2.33 & 0.00 & 0.00 & 0.00 & 0.00 & 0.00 & 0.00 & 0.00 \\
\hline CACA & $\begin{array}{l}\text { Calamagrostis } \\
\text { canadensis }\end{array}$ & bluejoint & FACW+ & yes & 9.78 & 0.00 & 0.00 & 0.00 & 0.00 & 0.00 & 0.00 & 0.00 \\
\hline CAHE & $\begin{array}{l}\text { Callitriche } \\
\text { heterophylla }\end{array}$ & Water starwort & $\mathrm{OBL}$ & es & 0.00 & 0.03 & 0.00 & 0.00 & 0.00 & 3.51 & 0.00 & 0.79 \\
\hline CALY & Carex lyngbyei & Lyngby sedge & $\mathrm{OBL}$ & yes & 60.38 & 0.00 & 0.00 & 0.00 & 0.00 & 0.00 & 0.00 & 0.00 \\
\hline CAOB & Carex obnupta & Slough sedge & $\mathrm{OBL}$ & yes & 0.00 & 0.00 & 0.00 & 0.00 & 0.00 & 3.02 & 0.00 & 4.93 \\
\hline CAPA & Caltha palustris & $\begin{array}{l}\text { Yellow marsh } \\
\text { marigold }\end{array}$ & $\mathrm{OBL}$ & yes & 0.00 & 0.00 & 0.00 & 0.00 & 0.00 & 0.00 & 0.00 & 0.29 \\
\hline CASE & Calystegia sepium & Hedge bindweed & FAC & no & 0.00 & 0.00 & 0.00 & 0.00 & 0.00 & 0.00 & 0.00 & 0.05 \\
\hline CASP & Carex sp. & Carex & mixed & yes & 0.00 & 0.00 & 0.00 & 0.00 & 0.00 & 0.25 & 0.00 & 0.00 \\
\hline CEDE & $\begin{array}{l}\text { Ceratophyllum } \\
\text { demersum }\end{array}$ & Coontail & $\mathrm{OBL}$ & yes & 0.00 & 0.00 & 0.00 & 0.00 & 0.20 & 0.00 & 0.00 & 0.00 \\
\hline COMA & Conium maculatum & Poison hemlock & FAC+ & no & 0.00 & 0.15 & 0.00 & 0.00 & 0.00 & 0.00 & 0.00 & 0.00 \\
\hline DECE & $\begin{array}{l}\text { Deschampsia } \\
\text { cespitosa }\end{array}$ & Tufted hairgrass & FACW & yes & 2.15 & 0.00 & 0.00 & 0.00 & 0.00 & 0.00 & 0.00 & 0.00 \\
\hline
\end{tabular}




\begin{tabular}{|c|c|c|c|c|c|c|c|c|c|c|c|c|}
\hline Code & Scientific Name & Common Name & Wetland Status & Native & BBM & BIM & CLM & CS1 & DIC & FLM & GIC & WHC \\
\hline DISP2 & Distichlis spicata & saltgrass & FACW & yes & 7.03 & 0.00 & 0.00 & 0.00 & 0.00 & 0.00 & 0.00 & 0.00 \\
\hline ELAC & Eleocharis acicularis & Needle spikerush & OBL & yes & 3.50 & 0.03 & 1.27 & 0.05 & 0.27 & 0.26 & 0.03 & 0.00 \\
\hline ELCA & Elodea canadensis & $\begin{array}{l}\text { Canada } \\
\text { waterweed }\end{array}$ & $\mathrm{OBL}$ & yes & 0.00 & 4.21 & 0.08 & 0.05 & 0.87 & 0.00 & 0.09 & 0.52 \\
\hline ELPA & Eleocharis palustris & $\begin{array}{l}\text { Common } \\
\text { spikerush }\end{array}$ & $\mathrm{OBL}$ & yes & 0.00 & 2.35 & 2.80 & 12.63 & 5.90 & 4.28 & 8.83 & 1.36 \\
\hline ELPAR & Eleocharis parvula & Dwarf spikerush & $\mathrm{OBL}$ & yes & 1.15 & 0.00 & 0.00 & 0.00 & 0.00 & 0.00 & 0.00 & 0.00 \\
\hline $\mathrm{EPCl}$ & Epilobium ciliatum & Willow herb & FACW- & yes & 0.00 & 0.00 & 0.00 & 0.00 & 0.00 & 0.00 & 0.00 & 0.14 \\
\hline EQFL & Equisetum fluviatile & Water horsetail & $\mathrm{OBL}$ & yes & 0.00 & 1.12 & 0.00 & 0.00 & 0.00 & 0.00 & 0.00 & 3.52 \\
\hline EQPA & Equisetum palustre & marsh horsetail & FACW & yes & 0.00 & 0.00 & 0.22 & 0.00 & 1.00 & 1.02 & 0.83 & 0.00 \\
\hline FRLA* & Fraxinus latifolia & Oregon ash & FACW & yes & 0.00 & 0.00 & 0.00 & 0.73 & 0.00 & 1.62 & 0.00 & 0.00 \\
\hline FUDI & Fucus distichus & Rockweed & $\mathrm{OBL}$ & yes & 0.53 & 0.00 & 0.00 & 0.00 & 0.00 & 0.00 & 0.00 & 0.00 \\
\hline GASP & Galium spp & $\begin{array}{l}\text { Pacific bedstraw; } \\
\text { cleavers; small } \\
\text { bedstraw }\end{array}$ & mixed & yes & 0.00 & 0.00 & 0.00 & 0.00 & 0.00 & 0.00 & 0.00 & 0.33 \\
\hline GLGR & Glyceria grandis & $\begin{array}{l}\text { American } \\
\text { mannagrass }\end{array}$ & $\mathrm{OBL}$ & yes & 0.38 & 0.00 & 0.00 & 0.00 & 0.00 & 0.00 & 0.00 & 0.62 \\
\hline HEAU & Helenium autumnale & $\begin{array}{l}\text { common } \\
\text { sneezeweed }\end{array}$ & FACW & yes & 0.00 & 0.00 & 0.00 & 0.00 & 0.37 & 0.08 & 0.14 & 0.00 \\
\hline IRPS & Iris pseudacorus & Yellow iris & $\mathrm{OBL}$ & no & 0.00 & 0.03 & 0.02 & 0.00 & 0.00 & 0.00 & 0.00 & 3.33 \\
\hline JUAR & $\begin{array}{l}\text { Juncus arcticus Wild. } \\
\text { ssp. littoralis }\end{array}$ & mountain rush & No & yes & 0.25 & 0.00 & 0.00 & 0.00 & 0.00 & 0.00 & 0.00 & 0.00 \\
\hline JUEN & Juncus ensifolius & Daggerleaf rush & FACW & yes & 0.00 & 0.00 & 0.00 & 0.00 & 0.00 & 0.00 & 0.29 & 0.00 \\
\hline JUOX & Juncus oxymeris & Pointed rush & FACW+ & yes & 0.00 & 0.00 & 0.00 & 0.08 & 0.00 & 0.00 & 0.00 & 0.12 \\
\hline LEMI & Lemna minor & Duckweed & $\mathrm{OBL}$ & yes & 0.00 & 0.12 & 0.00 & 0.02 & 0.00 & 0.00 & 0.00 & 0.00 \\
\hline LEOR & Leersia oryzoides & Rice cutgrass & $\mathrm{OBL}$ & yes & 0.00 & 0.12 & 0.00 & 0.00 & 0.00 & 1.08 & 0.00 & 0.62 \\
\hline LIAQ & Limosella aquatica & Water mudwort & $\mathrm{OBL}$ & yes & 0.00 & 0.00 & 0.00 & 0.00 & 0.00 & 0.02 & 0.00 & 0.00 \\
\hline $\mathrm{LIOC}$ & Lilaeopsis occidentalis & $\begin{array}{l}\text { Western } \\
\text { lilaeopsis }\end{array}$ & $\mathrm{OBL}$ & yes & 6.55 & 0.06 & 0.00 & 0.00 & 0.03 & 0.00 & 0.00 & 0.00 \\
\hline LOCO & Lotus corniculatus & Birdsfoot trefoil & FAC & no & 0.00 & 0.00 & 0.00 & 0.00 & 0.00 & 0.00 & 0.00 & 1.60 \\
\hline LUPA & Ludwigia palustris & False loosestrife & $\mathrm{OBL}$ & yes & 0.00 & 0.00 & 0.17 & 1.21 & 0.00 & 0.51 & 0.00 & 0.00 \\
\hline
\end{tabular}




\begin{tabular}{|c|c|c|c|c|c|c|c|c|c|c|c|c|}
\hline Code & Scientific Name & Common Name & Wetland Status & Native & BBM & BIM & CLM & CS1 & DIC & FLM & GIC & WHC \\
\hline LYAM & Lysichiton americanus & Skunk cabbage & $\mathrm{OBL}$ & yes & 0.00 & 0.00 & 0.00 & 0.00 & 0.00 & 0.00 & 0.00 & 0.29 \\
\hline LYNU & $\begin{array}{l}\text { Lysimachia } \\
\text { nummularia L. }\end{array}$ & $\begin{array}{l}\text { Moneywort, } \\
\text { Creeping Jenny }\end{array}$ & FACW & no & 0.00 & 0.00 & 0.00 & 1.21 & 1.20 & 0.00 & 0.00 & 0.00 \\
\hline LYSA & Lythrum salicaria & Purple loosestrife & $\mathrm{FACW}+$ & no & 0.00 & 0.00 & 0.00 & 0.00 & 0.20 & 0.00 & 0.14 & 0.55 \\
\hline MIGU & Mimulus guttatus & $\begin{array}{l}\text { Yellow } \\
\text { monkeyflower }\end{array}$ & OBL & yes & 0.00 & 0.00 & 0.00 & 0.00 & 0.00 & 0.00 & 0.00 & 0.14 \\
\hline MYSC & Myosotis scorpioides & $\begin{array}{l}\text { Common forget- } \\
\text { me-not }\end{array}$ & FACW & no & 0.00 & 0.00 & 0.00 & 0.00 & 0.00 & 0.00 & 0.00 & 1.00 \\
\hline MYSI & $\begin{array}{l}\text { Myriophyllum } \\
\text { sibiricum }\end{array}$ & $\begin{array}{l}\text { northern milfoil, } \\
\text { short spike milfoil }\end{array}$ & $\mathrm{OBL}$ & yes & 0.00 & 0.00 & 0.00 & 0.00 & 0.00 & 0.00 & 0.00 & 0.02 \\
\hline MYSP3 & $\begin{array}{l}\text { Myriophyllum } \\
\text { spicatum }\end{array}$ & $\begin{array}{l}\text { Eurasian water } \\
\text { milfoil }\end{array}$ & $\mathrm{OBL}$ & no & 0.00 & 0.00 & 0.00 & 0.00 & 0.00 & 0.00 & 0.00 & 0.00 \\
\hline OESA & Oenanthe sarmentosa & Water parsley & OBL & yes & 0.00 & 0.00 & 0.00 & 0.00 & 0.00 & 0.00 & 0.00 & 3.38 \\
\hline PHAR & Phalaris arundinacea & $\begin{array}{l}\text { Reed canary } \\
\text { grass }\end{array}$ & FACW & no & 0.00 & 6.21 & 15.59 & 33.55 & 17.47 & 23.69 & 15.37 & 56.79 \\
\hline PHAR-d & $\begin{array}{l}\text { dead Phalaris } \\
\text { arundinacea }\end{array}$ & $\begin{array}{l}\text { Reed canary } \\
\text { grass }\end{array}$ & FACW & no & 0.00 & 0.00 & 24.83 & 6.37 & 0.00 & 8.40 & 0.00 & 0.00 \\
\hline POAM & $\begin{array}{l}\text { Polygonum } \\
\text { amphibium }\end{array}$ & $\begin{array}{l}\text { water } \\
\text { ladysthumb, } \\
\text { water smartweed }\end{array}$ & OBL & yes & 0.00 & 0.00 & 0.00 & 0.02 & 0.00 & 9.89 & 0.00 & 0.00 \\
\hline POAN & $\begin{array}{l}\text { Potentilla anserina } \\
\text { ssp. } \\
\text { Pacifica/Argentina } \\
\text { egedii ssp. Egedii }\end{array}$ & Pacific silverweed & $\mathrm{OBL}$ & yes & 2.80 & 0.00 & 0.00 & 0.00 & 0.00 & 0.00 & 0.00 & 0.00 \\
\hline POCR & Potamogeton crispus & $\begin{array}{l}\text { Curly leaf } \\
\text { pondweed }\end{array}$ & $\mathrm{OBL}$ & no & 0.00 & 0.47 & 0.00 & 0.18 & 0.03 & 0.00 & 0.00 & 0.12 \\
\hline POHY & $\begin{array}{l}\text { Polygonum } \\
\text { hydropiper, P. } \\
\text { hydropiperoides }\end{array}$ & $\begin{array}{l}\text { Waterpepper, } \\
\text { mild } \\
\text { waterpepper, } \\
\text { swamp } \\
\text { smartweed }\end{array}$ & $\mathrm{OBL}$ & mixed & 0.00 & 0.15 & 0.00 & 0.00 & 0.00 & 0.08 & 0.03 & 0.69 \\
\hline PONA & Potamogeton natans & $\begin{array}{l}\text { Floating-leaved } \\
\text { pondweed }\end{array}$ & OBL & yes & 0.00 & 0.44 & 0.00 & 0.00 & 0.33 & 0.00 & 0.06 & 0.00 \\
\hline
\end{tabular}




\begin{tabular}{|c|c|c|c|c|c|c|c|c|c|c|c|c|}
\hline Code & Scientific Name & Common Name & Wetland Status & Native & BBM & BIM & CLM & CS1 & DIC & FLM & GIC & WHC \\
\hline PONO & $\begin{array}{l}\text { Potamogeton } \\
\text { nodosus }\end{array}$ & $\begin{array}{l}\text { longleaf } \\
\text { pondweed }\end{array}$ & $\mathrm{OBL}$ & yes & 0.00 & 0.00 & 0.34 & 0.00 & 0.00 & 0.00 & 0.00 & 0.00 \\
\hline POPE & Polygonum persicaria & $\begin{array}{l}\text { Spotted } \\
\text { ladysthumb }\end{array}$ & FACW & no & 0.00 & 1.24 & 0.15 & 0.00 & 0.20 & 0.00 & 0.00 & 0.05 \\
\hline POPU & Potamogeton pusillus & Small pondweed & OBL & yes & 0.00 & 0.00 & 0.00 & 0.00 & 0.00 & 0.00 & 0.00 & 0.02 \\
\hline PORI & $\begin{array}{l}\text { Potamogeton } \\
\text { richardsonii }\end{array}$ & $\begin{array}{l}\text { Richardson's } \\
\text { pondweed }\end{array}$ & $\mathrm{OBL}$ & yes & 0.00 & 0.00 & 0.00 & 0.00 & 0.00 & 0.00 & 0.00 & 0.36 \\
\hline POZO & $\begin{array}{l}\text { Potamogeton } \\
\text { zosteriformis }\end{array}$ & $\begin{array}{l}\text { Eelgrass } \\
\text { pondweed }\end{array}$ & $\mathrm{OBL}$ & yes & 0.00 & 0.03 & 0.00 & 0.00 & 0.00 & 0.00 & 0.00 & 0.00 \\
\hline RUCR & Rumex crispus & Curly dock & $\mathrm{FAC}+$ & no & 0.00 & 0.00 & 0.00 & 0.00 & 0.00 & 0.00 & 0.00 & 0.24 \\
\hline RUMA & Rumex maritimus & $\begin{array}{l}\text { Golden dock, } \\
\text { seaside dock }\end{array}$ & $\mathrm{FACW}+$ & yes & 0.00 & 0.00 & 0.00 & 0.08 & 0.03 & 0.00 & 0.00 & 0.05 \\
\hline SALA & Sagittaria latifolia & Wapato & $\mathrm{OBL}$ & yes & 0.00 & 14.65 & 2.32 & 5.81 & 1.93 & 2.09 & 0.80 & 4.07 \\
\hline SALU & Salix lucida & Pacific willow & $\mathrm{FACW}+$ & yes & 0.00 & 0.00 & 0.00 & 0.00 & 0.20 & 3.31 & 0.00 & 0.00 \\
\hline SALU* & Salix lucida & Pacific willow & $\mathrm{FACW}+$ & yes & 0.00 & 1.91 & 5.51 & 0.97 & 0.20 & 3.31 & 5.00 & 0.00 \\
\hline SASI & Salix sitchensis & Sitka willow & FACW & yes & 0.00 & 0.00 & 0.00 & 0.00 & 0.00 & 0.00 & 0.00 & 1.79 \\
\hline SCAM & $\begin{array}{l}\text { Schoenoplectus } \\
\text { americanus }\end{array}$ & $\begin{array}{l}\text { American } \\
\text { bulrush, } \\
\text { threesquare } \\
\text { bulrush }\end{array}$ & $\mathrm{OBL}$ & yes & 2.90 & 0.00 & 0.00 & 0.00 & 0.00 & 0.00 & 0.00 & 0.14 \\
\hline SCMA & $\begin{array}{l}\text { Schoenoplectus } \\
\text { maritimus }\end{array}$ & Seacoast bulrush & $\mathrm{OBL}$ & yes & 0.13 & 0.00 & 0.00 & 0.00 & 0.00 & 0.00 & 0.00 & 0.00 \\
\hline SCTA & $\begin{array}{l}\text { Schoenoplectus } \\
\text { tabernaemontani }\end{array}$ & $\begin{array}{l}\text { Softstem bulrush, } \\
\text { tule }\end{array}$ & $\mathrm{OBL}$ & Yes & 0.00 & 0.74 & 0.00 & 0.02 & 0.00 & 0.15 & 0.00 & 0.00 \\
\hline SISU & Sium suave & $\begin{array}{l}\text { Hemlock } \\
\text { waterparsnip }\end{array}$ & $\mathrm{OBL}$ & yes & 0.00 & 0.00 & 0.00 & 0.00 & 0.00 & 0.00 & 0.00 & 0.38 \\
\hline SODU & Solanum dulcamara & $\begin{array}{l}\text { Bittersweet } \\
\text { nightshade }\end{array}$ & FAC+ & no & 0.00 & 0.00 & 0.00 & 0.00 & 0.00 & 0.00 & 0.00 & 0.48 \\
\hline SPAN & $\begin{array}{l}\text { Sparganium } \\
\text { angustifolium }\end{array}$ & $\begin{array}{l}\text { Narrowleaf } \\
\text { burreed }\end{array}$ & $\mathrm{OBL}$ & yes & 0.00 & 0.00 & 0.25 & 0.00 & 0.00 & 0.00 & 0.00 & 0.02 \\
\hline SYSU & $\begin{array}{l}\text { Symphyotrichum } \\
\text { subspicatum }\end{array}$ & Douglas aster & FACW & yes & 0.38 & 0.00 & 0.00 & 0.00 & 0.00 & 0.00 & 0.00 & 0.00 \\
\hline TRMA & Triglochin maritima & $\begin{array}{l}\text { Seaside } \\
\text { arrowgrass }\end{array}$ & OBL & yes & 4.63 & 0.00 & 0.00 & 0.00 & 0.00 & 0.00 & 0.00 & 0.00 \\
\hline
\end{tabular}




\begin{tabular}{|c|c|c|c|c|c|c|c|c|c|c|c|c|}
\hline Code & Scientific Name & Common Name & Wetland Status & Native & BBM & BIM & CLM & CS1 & DIC & FLM & GIC & WHC \\
\hline TYAN & Typha angustifolia & $\begin{array}{l}\text { Narrowleaf } \\
\text { cattail }\end{array}$ & $\mathrm{OBL}$ & no & 1.15 & 0.00 & 0.00 & 0.00 & 0.00 & 0.00 & 0.00 & 3.17 \\
\hline VEAM & Veronica americana & $\begin{array}{l}\text { American } \\
\text { speedwell }\end{array}$ & $\mathrm{OBL}$ & yes & 0.00 & 0.00 & 0.00 & 0.00 & 0.07 & 0.00 & 0.00 & 0.00 \\
\hline ZAPA & Zannichellia palustris & $\begin{array}{l}\text { horned } \\
\text { pondweed }\end{array}$ & OBL & yes & 2.75 & 0.00 & 0.00 & 0.00 & 0.00 & 0.00 & 0.00 & 0.00 \\
\hline
\end{tabular}






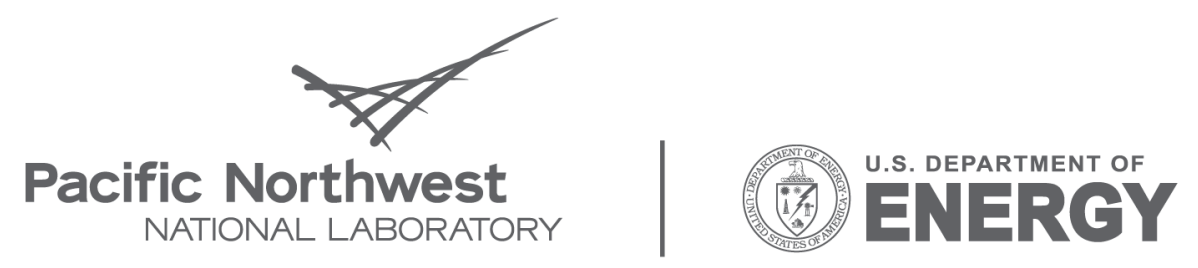

Proudly Operated by Battelle Since 1965

902 Battelle Boulevard

P.O. Box 999

Richland, WA 99352

1-888-375-PNNL (7665)

www.pnl.gov 